\title{
Evaluatie van het School-Ex 2.0 programma. De rol van studiekeuze- en exitgesprekken in het MBO
}

Citation for published version (APA):

Meng, C. M., Verhagen, A. M. C., Korthals, R. A., \& Huijgen, T. G. (2014). Evaluatie van het School-Ex 2.0 programma. De rol van studiekeuze- en exitgesprekken in het MBO. ROA. ROA Reports No. 002 https://doi.org/10.26481/umarep.2014002

Document status and date:

Published: 01/01/2014

DOI:

10.26481/umarep.2014002

Document Version:

Publisher's PDF, also known as Version of record

\section{Please check the document version of this publication:}

- A submitted manuscript is the version of the article upon submission and before peer-review. There can be important differences between the submitted version and the official published version of record.

People interested in the research are advised to contact the author for the final version of the publication, or visit the DOI to the publisher's website.

- The final author version and the galley proof are versions of the publication after peer review.

- The final published version features the final layout of the paper including the volume, issue and page numbers.

Link to publication

\footnotetext{
General rights rights.

- You may freely distribute the URL identifying the publication in the public portal. please follow below link for the End User Agreement:

www.umlib.nl/taverne-license

Take down policy

If you believe that this document breaches copyright please contact us at:

repository@maastrichtuniversity.nl

providing details and we will investigate your claim.
}

Copyright and moral rights for the publications made accessible in the public portal are retained by the authors and/or other copyright owners and it is a condition of accessing publications that users recognise and abide by the legal requirements associated with these

- Users may download and print one copy of any publication from the public portal for the purpose of private study or research.

- You may not further distribute the material or use it for any profit-making activity or commercial gain

If the publication is distributed under the terms of Article $25 \mathrm{fa}$ of the Dutch Copyright Act, indicated by the "Taverne" license above, 


\section{Evaluatie van het School-Ex 2.0 programma De rol van studiekeuze- en exitgesprekken in het $\mathrm{MBO}$}

Christoph Meng

Annelore Verhagen

Roxanne Korthals

Timo Huijgen

ROA-R-2014/2

Researchcentrum voor Onderwijs en Arbeidsmarkt

Maastricht University

School of Business and Economics

Maastricht, mei 2014 


\section{Colofon}

(C) Researchcentrum voor Onderwijs en Arbeidsmarkt (ROA). Niets uit deze uitgave mag op enige manier worden verveelvoudigd zonder voorafgaande schriftelijke toestemming van de directeur van het ROA.

\section{Researchcentrum voor Onderwijs en Arbeidsmarkt}

Maastricht University

School of Business and Economics

\section{Vormgeving}

ROA secretariaat, Maastricht

\section{Verkoop}

Researchcentrum voor Onderwijs en Arbeidsmarkt email: secretary-roa-sbe@maastrichtuniversity.nl website: www.roa.nl

ISBN: 978-90-532I-525-8

mei 2014 


\section{INHOUD}

Voorwoord $\quad$ V

Resumé VII

$1 \quad$ Inleiding 1

2 Data en instrumenten: Het formele en informele circuit van gesprekken 5

2.1 Databronnen 5

2.2 Het formele en het informele circuit van gesprekken 9

3 Exitgesprekken 17

3.1 Evaluatie van het formele circuit van exitgesprekken 19

3.2 De waarde van Exitgesprekken: Het informele circuit 28

4 Ombuigingsgesprekken/Studiekeuzegesprekken $\quad 43$

4.1 Inleiding 43

4.2 Wie heeft de studiekeuze besproken? $\quad 47$

$\begin{array}{ll}4.3 \text { Wie is er van studiekeuze gewisseld? } & 50\end{array}$

4.4 Hebben studiekeuzegesprekken de studiekeuze van de
studiewisselaars naar eigen zeggen beïnvloed?

4.5 Ingeschatte arbeidsmarktperspectieven van de eerste en

4.6 Conclusies 'Ombuigingsgesprekken/studiekeuzegesprekken' $\quad 59$

$\begin{array}{ll}\text { Bijlagen } & 61\end{array}$ 



\section{VOORWOORD}

In het voorjaar van 2013 verkeerde Nederland voor het vijfde jaar in een economische malaise. Om het oplopen van de jeugdwerkloosheid te temperen, zijn de (aanstaande) gediplomeerden van het MBO in de zomer middels het School Ex 2.o programma aangespoord om door te leren. Hiermee is getracht om een vervolg te geven aan het eerste School Ex programma dat in de jaren 2009 en 2010 is uitgevoerd. Het recente programma dat in 2013 gestart is, is daarbij uitgebreid met zogenaamde Ombuigingsgesprekken. Deze gesprekken zijn bedoeld om jongeren die instromen in het $\mathrm{MBO}$ en zich aanmelden voor een opleiding met in het algemeen slechte arbeidsmarktperspectieven, in gesprekken om te buigen naar opleidingen met betere arbeidsmarktperspectieven.

Het Ministerie van Onderwijs, Cultuur en Wetenschap, het Ministerie van Sociale Zaken en Werkgelegenheid en het Ministerie van Economische Zaken hebben het Researchcentrum voor Onderwijs en Arbeidsmarkt (ROA) van Maastricht University gevraagd om het School Ex 2.0 programma te evalueren. In het voorliggende rapport wordt over de evaluatie van het eerste jaar van het School Ex 2.0 programma verslag gedaan. Over de evaluatie van het tweede jaar van het School Ex 2.o programma wordt in het voorjaar van 2015 via een apart rapport verslag gedaan.

De projectleiding van deze evaluatie berust bij dr. C. Meng. Het rapport is geschreven door dr. C. Meng, drs. A. Verhagen, drs. R. Korthals en drs. T. Huijgen. De eindredactie is in handen van dr. C. Meng. Secretariële ondersteuning is verleend door M. Retz en E. Soudant. Voornoemde personen zijn allen werkzaam bij het ROA. Aan de totstandkoming van het databestand waarop dit rapport is gebaseerd, werkten verder mee drs. M. van Alphen, drs. J. van Dongen en drs. B. Kinket (allen werkzaam bij DESAN Research Solutions). Speciale dank is gericht aan Jaap-Jan Bakker (werkzaam bij de Dienst Uitvoering Onderwijs) voor de medewerking bij het uitzetten van de steekproef onder de gediplomeerden van het MBO en het VMBO alsmede voor het beschikbaar stellen van de BRON data.

Een speciaal woord van dank wordt gericht aan de leden van de begeleidingscommissie: drs. drs. Bernard Verlaan, drs. Andre de Moor, drs. Frank Koster, drs. Ted Reininga (allen werkzaam bij het Ministerie van Onderwijs, Cultuur en Wetenschap), drs. Maurice Doll (werkzaam bij het Ministerie van Sociale Zaken en Werkgelegenheid), drs. Huib van der Kroon (Ministerie van Economische Zaken), dr. Marc van der Steeg (werkzaam bij het Centraal Planbureau), Pierre Veelenturf (werkzaam bij de MBO Raad), drs. Arie Leeman (werkzaam bij ROC Midden Nederland) alsmede drs. Mark Wanna (werkzaam bij het ROC van Amsterdam en Flevoland). 



\section{RESUMÉ}

Kiezen voor een $\mathrm{MBO}$-opleiding met het hart of nadat een afweging van toekomstige arbeidsmarktperspectieven is gemaakt? $\mathrm{Na}$ het behalen van het $\mathrm{MBO}$-diploma doorleren of zich aanbieden op de arbeidsmarkt? Jongeren staan precies voor deze keuzes. In de afgelopen vijf jaren kreeg deze afweging wegens de voortdurende economische malaise nog een zwaardere lading dan in tijden van hoogconjunctuur. De verwachting dat in Nederland de jeugdwerkloosheid ook in 2013 en de jaren daarna verder zou kunnen oplopen, heeft in het voorjaar van 2013 dan ook tot een brede aanpak geleid om jongeren aan te sporen om voor een $\mathrm{MBO}$-opleiding met goede arbeidsmarktperspectieven te kiezen en na behalen van het MBO-diploma door te leren, zij het in het $\mathrm{MBO}$ zelf dan wel bijvoorbeeld in het $\mathrm{HBO}$. Maar wat zijn de gevolgen van deze brede aanpak? Hebben jongeren zich door deze activiteiten laten beïnvloeden? Is het gelukt om het aandeel MBO-gediplomeerden dat de onderwijs carrière voortzet te verhogen? Laten de gediplomeerden van het VMBO zich door arbeidsmarkperspectieven beïnvloeden en kiezen ze voor MBO-opleidingen met goede arbeidsmarktperspectieven? Navolgend presenteren we de centrale conclusies van de Evaluatie van het School Ex 2.0 programma zoals uitgevoerd in de periode oktober 2013 tot en met april 20I4. Deze resultaten hebben betrekking op a) een enquête onder MBO-scholen, b) een enquête onder $\mathrm{MBO}$-gediplomeerden van het schooljaar 20I2/2OI3, c) een enquête onder gediplomeerden van het VMBO die in het schooljaar 20I3/20I4 in een MBO-BOL opleiding ingestroomd zijn en d) een analyse van registerdata afkomstig van de Dienst Uitvoering Onderwijs van het Ministerie van OCW.

\section{Exitgesprekken}

\section{De omvang van exitgesprekken}

Exitgesprekken worden op grote schaal gevoerd: In het schooljaar 2012/2013 zijn door MBOscholen op grote schaal exitgesprekken met (aanstaande) gediplomeerden gevoerd. $92 \%$ van de school-domein combinaties meldt dat exitgesprekken hebben plaatsgevonden en $70 \%$ van de gediplomeerde MBO-ers meldt minimaal I keer met een medewerker van school over zijn/haar toekomstplannen gesproken te hebben. In de domeinen techniek en economie is de kans op een exitgesprek significant lager.

\section{De rol van het School Ex 2.0 programma}

Geen verhoging van aandeel dat doorstroomt: Op basis van de analyses dient vastgesteld te worden dat, ten minste in het eerste jaar van het programma, niet kan worden aangetoond 
dat de nadruk op exitgesprekken binnen het School Ex 2.0 programma heeft geleid tot een verhoging van het aandeel $\mathrm{MBO}$-gediplomeerden dat de onderwijscarrière voortzet.

Van informeel naar formeel circuit: De analyses laten zien dat $\mathrm{MBO}$ breed al voorafgaand aan het schooljaar 20I2/20I3 een informeel circuit van exitgesprekken bestond. Dat wil zeggen dat docenten, mentoren of bijvoorbeeld studieloopbaanbegeleiders al langer gesprekken met (aanstaande) gediplomeerden voeren over hun (nabije) toekomstplannen en wat ze het best kunnen met de capaciteiten opgedaan in de afgeronde opleiding, zonder dat daar op school- of bijvoorbeeld locatieniveau regels of protocollen voor bestonden. De nadruk op exitgesprekken binnen het School Ex 2.0 programma lijkt ertoe te hebben geleid dat in scholen waar dit nog niet de gangbare norm was (28\% van de scholen die aan de enquête hebben deelgenomen), een 'formeel circuit' van exitgesprekken is opgestart. Dit kan tot een verdergaande professionaliteit in het voeren van exitgesprekken leiden. Of deze verdergaande professionaliteit in de toekomst ook tot een verhoging van het aandeel dat doorstroomt naar het vervolgonderwijs leidt, dient in de toekomst nader onderzocht te worden.

\section{De beïnvloeding door exitgesprekken en het nut ervan (informele circuit)}

Gemiddeld ruim een kwart van de jongeren die een exitgesprek hebben gehad geeft aan hierdoor in de keuze wat de vervolgstappen betreft beïnloed te zijn: De beïnvloeding vindt plaats op het vlak van diverse keuzes. Het gaat om de keuze om door te leren $(4 \%)$, een andere vervolgopleiding te gaan volgen dan men eerst van plan was $(5 \%)$, te gaan werken (6\%), of anders (I2\%). Exitgesprekken beïnvloeden daarmee in beperkte mate de keuzes ten aanzien van verdere scholing van jongeren.

Responsiviteit verschilt tussen groepen van jongeren en geeft mogelijkheid om instrumenten doelmatiger in te zetten: De mate van beïnvloeding is hoger bij gediplomeerden van lagere niveaus, gering bij de hogere MBO-BOL niveaus en zeer gering bij de hogere $\mathrm{MBO}-\mathrm{BBL}$ niveaus. Conditioneel op het opleidingsniveau worden niet-westerse allochtonen sterker beïnvloed door exitgesprekken. Indien door budgetrestricties (tijd, geld) keuzes gemaakt dienen te worden, is het dan ook aan te raden om exitgesprekken te focussen op de (aanstaande) gediplomeerden van lagere MBO niveaus en de groep niet-westerse allochtonen.

Exitgesprekken als middel om jongeren op de goede plek te brengen: Exitgesprekken zijn niet per definitie gericht op het verhogen van de doorstroom naar het vervolgonderwijs, maar op het ondersteunen van jongeren bij hun keuze voor de eerstvolgende stappen na het behalen van het diploma. Jongeren die een exitgesprek hebben gehad en doorleren lijken dan ook eerder tevreden te zijn met de gemaakte studiekeuze, en jongeren die een exitgesprek hebben gehad en zich op de arbeidsmarkt aanbieden lijken een hogere kans op werk te hebben. 
Exitgesprekken worden zowel door scholen als door leerlingen als nuttig ervaren: 50\% van de gediplomeerde $\mathrm{MBO}$-ers vond het exitgesprek nuttig dan wel heel nuttig. Onder de groep jongeren die door het gesprek is beïnvloed in de keuze om al dan niet door te leren is dit percentage zelfs $59 \%$. Ook een overgrote meerderheid van de bevraagde schooldomein combinaties (8I\%) geeft aan dat de exitgesprekken als (heel) nuttig zijn ervaren.

\section{De waarde van studiekeuzegesprekken met VMBO-gediplomeerden die in het MBO- BOL instromen}

Veel VMBO-ers twijfelen over hun studiekeuze: $17 \%$ van de VMBO-gediplomeerden start uiteindelijk met een andere MBO-BOL opleiding dan hij of zij oorspronkelijk van plan was. Nog eens $28 \%$ twijfelde tussen een aantal MBO-BOL opleidingen. Als ombuigingsgesprekken effect hebben, dan zijn het deze groepen leerlingen waar het effect het grootst zal zijn.

Ombuigingsgesprek heeft gemiddeld een beperkt effect op studiekeuze: Tussen de 4 en maximaal Io procent van de respondenten wordt door een studiekeuzegesprek omgebogen naar andere studie.

Veel studiekeuzegesprekken met VMBO-gediplomeerden maar minder vaak ombuigingsgesprekken: Een ruime meerderheid (66\%) van de jongeren die in het schooljaar 2013/20I4 met een MBO-BOL opleiding is gestart, geeft aan dat ze hun opleidingskeuze besproken hebben op hun huidige MBO-school. De helft van de ondervraagde school-domein combinaties laat echter weten dat er geen 'ombuigingsgesprekken' hebben plaatsgevonden. Opvallend is dat daarbij $20 \%$ van de school-domein combinaties als reden aanvoert dat dit ten koste gaat van de instroom. Dat suggereert dat in sommige gevallen de belangen van de instelling niet parallel lopen met die van de student. Vergelijkbaar belangrijke aangevoerde redenen zijn 'geen tijd' of 'geen nut'.

Studiekeuzegesprekken beïnvloeden keuze van jongeren en worden als nuttig ervaren: Een op de drie jongeren die een studiekeuzegesprek heeft gehad geeft aan hierdoor (sterk) beïnvloed te zijn en twee op de drie heeft het studiekeuzegesprek als (heel) nuttig ervaren.

Arbeidsmarktperspectieven zijn van belang bij de keuze: Jongeren die kennis hebben van de slechte arbeidsmarktperspectieven van een opleiding (of in elk geval van mening zijn dat de perspectieven slecht zijn) kiezen eerder voor een andere opleiding. Deze uitkomst ondersteunt de aan het School Ex 2.0 onderliggende assumptie dat jongeren die kennis hebben van slechte arbeidsmarktperspectieven eerder een andere studie zullen kiezen. $42 \%$ van de jongeren die voor de start van de opleiding van studiekeuze gewisseld zijn hebben het idee dat de kansen op het vinden van een baan daardoor (aanzienlijk) beter zullen zijn.

Ook jongeren met problemen in de leefomgeving zijn beïnloedbaar: Jongeren die aangegeven dat ze in het afgelopen jaar veelvoudige contacten met justitie of politie hebben gehad 
en/of veelvuldig gebruik maakten van internet/gokspellen/computergames, hebben een significant grotere kans dan degenen die deze problemen niet melden, om aan te geven dat ze vanwege het studiekeuzegesprek van studiekeuze zijn gewisseld. Dit resultaat laat zien dat de groep jongeren, die vaak als een lastig bereikbare groep jongeren gezien wordt, door studiekeuze gesprekken op scholen wel beïnvloedbaar is. 


\section{1}

\section{INLEIDING}

De stand van de conjunctuur is bepalend voor de arbeidsmarktdeelname onder de potentiële beroepsbevolking. Dit geldt in het bijzonder voor jongeren (die nog geen gevestigde plaats op de arbeidsmarkt hebben verworven en als eerste worden ontslagen indien het bedrijf waarvoor zij werken het moeilijk krijgt) en voor schoolverlaters (die moeilijker aan hun eerste baan kunnen komen). Sinds het begin van de recente economische crisis eind 2008 is de jeugdwerkloosheid en de werkloosheid onder recent gediplomeerden dan ook snel opgelopen. De werkloosheid onder recent gediplomeerden van het MBO (gemeten anderhalf jaar na behalen van diploma) wordt in Figuur I.I geillustreerd. Terwijl de werkloosheid onder de recent gediplomeerden in 2008 (gediplomeerden van het schooljaar 2006-2007) nog bij 5\% (MBO-BOL), respectievelijk I\% (MBO-BBL) lag, is van de groep gediplomeerden van het schooljaar 2OII-2OI2 die in het najaar van 2013 is bevraagd $17 \%$, respectievelijk $5 \%$ werkloos. In het geval van de gediplomeerden van het $\mathrm{MBO}-\mathrm{BOL}$ komt dit neer op meer dan een verdrievoudiging van de kans op werkloosheid, en onder de gediplomeerden van het MBO-BBL is het zelfs een vervijfvoudiging.

\section{Figuur 1.1}

Werkloosheid (\%) van recent gediplomeerden van het MBO (18 maanden na behalen van diploma)

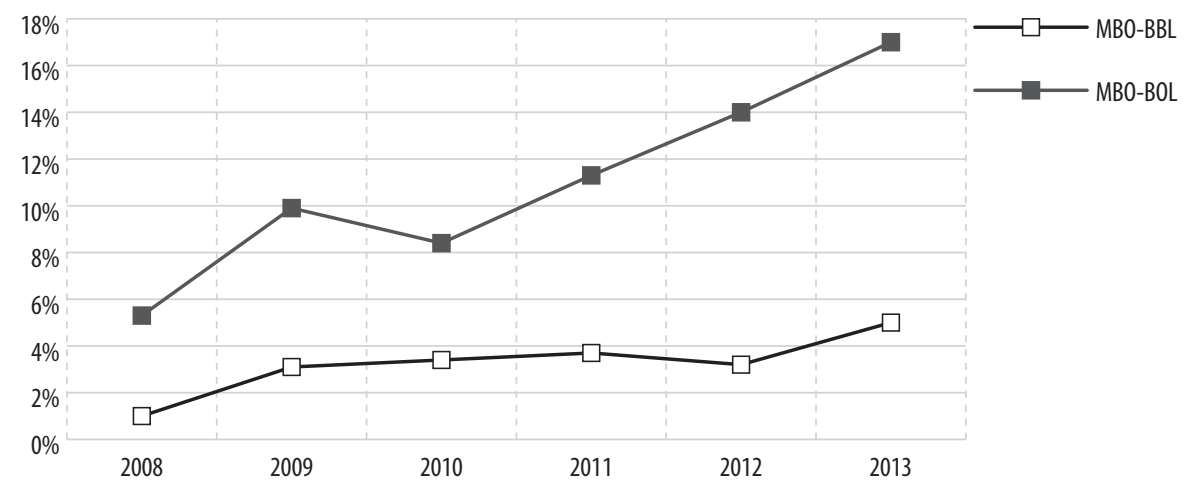

Bron: BVE-Monitor, ROA (2008-2013)

Een economische crisis beperkt zich niet tot arbeidsmarkteffecten alleen. Ook zal de beslissing die recent gediplomeerden moeten maken met betrekking tot het wel of niet gaan 
volgen van vervolgonderwijs nog belangrijker worden dan die al was; iets waar ook overheden de afgelopen jaren al op inspelen. Zo is in 2009 als meer recent in 2013 een Aanpak Jeugdwerkloosheid gestart. Een belangrijk onderdeel van de Aanpak Jeugdwerkloosheid is het School Ex Programma met als doel jeugdwerkloosheid te reduceren en voorkomen. Zowel het eerste School Ex Programma in de periode 2009/2010 als het recente School Ex 2.o ProgrammaI dat in 2013 gestart is, bestaat in hoofdlijnen uit twee elementen, namelijk een registratie van de toekomstplannen van $\mathrm{MBO}$ examenkandidaten (de zogenaamde 'mobiliteitsregistratie') en het bieden van (individuele) opleidingsadviezen. Het recente programma dat in 2013 gestart is, is daarbij nog uitgebreid met zogenaamde Ombuigingsgesprekken. Deze gesprekken zijn bedoeld om jongeren die instromen in het $\mathrm{MBO}$ en zich aanmelden voor een opleiding met in het algemeen slechte arbeidsmarktperspectieven, in gesprekken om te buigen naar opleidingen met betere arbeidsmarktperspectieven.

In het najaar van 2013 is het Researchcentrum voor Onderwijs en Arbeidsmarkt van Maastricht University gevraagd om de effecten van het School Ex 2.0 programma, en meer specifiek de effecten wat de Exitgesprekken en de Ombuigingsgesprekken te evalueren.

Doelstelling van de evaluatie was om op volgende vragen een antwoord te vinden:

a. Wat is het effect van het School Ex 2.o programma op het aandeel MBO gediplomeerden dat verder gaat studeren?

b. Wat is het effect van het School Ex 2.0 programma op het aandeel VMBO gediplomeerden dat in plaats van voor een opleiding met weinig arbeidsperspectief in de regio, een opleiding met meer arbeidsmarktperspectief is gaan volgen?

c. Welke jongeren hebben een exitgesprek/ombuigingsgesprek gehad en hoe zijn ze daardoor beïnvloed?

Via vragen a) en b) trachten we vast te stellen wat het algemene 'treatment effect' van het School Ex 2.o programma is en met vraag c) of de sterkte van het 'treatment' of de manier waarop het 'treatment' wordt toegepast van belang is. Om op de drie centrale vragen een antwoord te krijgen, is in het kader van de evaluatie een viertal data met elkaar in verband gebracht:

- Registerdata afkomstig van de Dienst Uitvoering Onderwijs

- Enquête onder scholen die MBO opleidingen aanbieden

- Enquête onder MBO gediplomeerden die in het schooljaar 2012/2013 hun diploma hebben behaald

- Enquête onder VMBO gediplomeerden die in het schooljaar 20I2/20I3 hun $\mathrm{VMBO}$ diploma hebben behaald en direct aansluitend aan een $\mathrm{MBO}$ opleiding zijn begonnen

I. School Ex 2.0 programma is vergelijkbaar met het School Ex I.o programma ingericht voor een tweetal schooljaren (2012/2OI3 en 20I3/2OI4). Het voorliggende rapport gaat daarbij alleen over het eerste jaar van dit programma. 
Het rapport is als volgt opgebouwd. In hoofdstuk 2 staan we nader stil bij de vier databronnen die in het kader van deze evaluatie geanalyseerd zijn. We bespreken de manier van dataverzameling, de betrouwbaarheid van de data en eventuele tekortkomingen. Daarnaast laat hoofdstuk 2 ook zien dat er bij de exitgesprekken een onderscheid gemaakt dient te worden tussen het formele circuit' en een het 'informele circuit' van exitgesprekken. Het eerste circuit bestaat uit exitgesprekken die bijvoorbeeld door een school- dan wel domein- of locatie-breed protocol of aanpak geregeld zijn. Het tweede circuit bestaat uit gesprekken die vooral door docenten en mentoren gevoerd worden zonder dat daar een bepaald protocol of duidelijke interne afspraken voor bestaan en die misschien vaak niet eens geregistreerd worden.

In hoofdstuk 3 analyseren we in eerste instantie in hoeverre de nadruk van het School Ex 2.0 programma op exitgesprekken tot een verhoging van het aandeel jongeren heeft geleid dat met een vervolgopleiding gestart is. In tweede instantie gaan we op basis van de enquêtes onder de jongeren nader in op de waarde van exitgesprekken en analyseren we in hoeverre de invloed van exitgesprekken verschilt tussen bijvoorbeeld de gediplomeerden van niveau $\mathrm{I} / 2$ opleidingen en de gediplomeerden van niveau $3 / 4$ opleidingen, dan wel tussen de gediplomeerden van de beroeps opleidende leerweg en de gediplomeerden van de beroepsbegeleidende leerweg.

In hoofdstuk 4 staan we tot slot stil bij de vraag of de gediplomeerden van het VMBO die zich aanmelden voor een MBO-BOL opleiding hun studiekeuze op de MBO school bespreken en of deze gesprekken de uiteindelijke studiekeuze beïnvloeden. Onder andere stellen we daarbij de vraag in hoeverre jongeren zich door arbeidsmarktperspectieven laten leiden. 



\section{2}

\section{DATA EN INSTRUMENTEN: HET FORMELE EN INFORMELE CIRCUIT VAN GESPREKKEN}

Een betrouwbare evaluatie van een beleidsmaatregel is afhankelijk van betrouwbare databronnen. Voordat we in de navolgende hoofdstukken dan ook nader analyseren wat de effecten van het School Ex 2.0 programma zijn, staan we in dit hoofdstuk stil bij de gebruikte databronnen en de daaruit afgeleide instrumenten. We doen dit in een tweetal stappen. In eerste instantie (paragraaf 2.I) presenteren we kort de gebruikte databronnen, en in het geval van de databronnen afkomstig van enquêtes, de manier van dataverzameling. In tweede instantie (paragraaf 2.2) stellen we nader de cruciale vragen 'wat meten we precies met welke enquête?' en 'meten de enquêtes hetzelfde?'.

\subsection{Databronnen}

Navolgend staan we kort stil bij de vier databronnen waarop deze evaluatie is gebaseerd. We starten bij de registerdata afkomstig van de Dienst Uitvoering Onderwijs (DUO) van het Ministerie van Onderwijs, Cultuur en Wetenschap, gevolgd door een bespreking van de drie enquêtes uitgevoerd in het kader van deze evaluatie, namelijk de enquête onder $\mathrm{MBO}$ scholen, de enquête onder de recent gediplomeerden van het $\mathrm{MBO}$ en de enquête onder de recent in het $\mathrm{MBO}$ ingestroomde gediplomeerden van het VMBO.

\section{Registerdata van DUO}

Via de BRON data van DUO is het mogelijk om voor afzonderlijke jaren, en per opleiding en school, vast te stellen welk deel van de $\mathrm{MBO}$-gediplomeerden (direct aansluitend aan het behalen van het diploma) voor een vervolgopleiding heeft gekozen, en aan welke $\mathrm{MBO}$ opleidingen VMBO-gediplomeerden zijn begonnen. Voor de voorliggende analyses zijn daarbij data afkomstig van de schooljaren 2005/2006 tot en met 2012/2013 voor de exitgesprekken en van de schooljaren 2009/20Io tot en met 2013/20I4 voor de ombuigingsgesprekken nader geanalyseerd.

Figuur 2.I laat per leerweg het percentage MBO-gediplomeerden zien dat op I oktober van het eerstvolgende schooljaar in een bekostigde opleiding in Nederland ingeschreven staat. Wat de gediplomeerden van het MBO-BOL betreft zien we tussen 2005/2006 en $2007 / 2008$ een lichte daling in de doorstroom en, na een korte opleving onder de gediplo- 
meerden van het schooljaar 2008/2009 wederom tot het schooljaar 20II/20I2 een lichte daling. Van de gediplomeerden van het schooljaar 2012/2013 stroomt dan wederom een licht hoger percentage (+2\%-punt) door naar een vervolgopleiding in vergelijking met de gediplomeerden van het schooljaar 20II/20I2. Wat de gediplomeerden van het MBO-BBL betreft is het opvallend dat de daling in het percentage dat doorstroomt later inzet (tot $2008 / 2009$ is er geen daling zichtbaar) maar deze zich daarna sterker doorzet en uiteindelijk in de jaren $201 \mathrm{I} / 20 \mathrm{I} 2$ en $2012 / 2013$ resulteert in een doorstroom van rond de $20 \%$. De daling komt daarbij overeen met de jaren van economische crisis in Nederland en kan daarmee het gevolg zijn van het verdwijnen van leerplekken bij bedrijven. Daarnaast is wat de gediplomeerden van het MBO-BBL betreft geen opleving zichtbaar in de schooljaren 2008/2009 en 2012/2013.

\section{Figuur 2.1}

Percentage MBO-gediplomeerden dat is doorgestroomd naar vervolgonderwijs, per leerweg

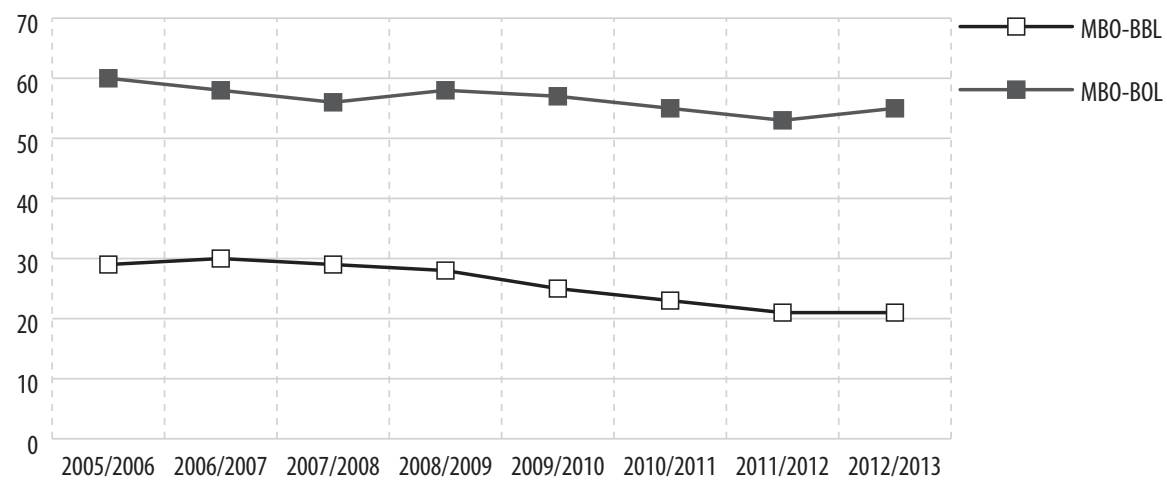

Bron: DUO, eigen bewerking ROA

Tabel 2.I laat zien dat niet alleen het percentage jongeren dat na het behalen van een $\mathrm{MBO}-\mathrm{BBL}$ diploma is doorgestroomd naar een vervolgopleiding als gevolg van de crisis afgenomen is, maar dat dit ook geldt voor het percentage gediplomeerden van het $\mathrm{VMBO}$ dat in het MBO-BBL is ingestroomd. Startte van de pakweg 91.00o VMBOgediplomeerden die in het schooljaar 2009/20IO voor een vervolgopleiding in het MBO koos $12 \%$ met een opleiding in het MBO-BBL, in 20I3-30I4 is dit nog zo'n 8\% (van zo'n 88.000 scholieren). Daarmee is het aantal VMBO-gediplomeerden dat met een MBO-BBL opleiding startte in vijf jaar tijd gedaald van net geen II.ooo naar minder dan 7.000.

\section{Tabel 2.1}

Instroom in $\mathrm{MBO}$ vanuit VMBO en Verdeling $\mathrm{BOL}-\mathrm{BBL}(\%)$

\begin{tabular}{|l|r|r|r|r|r|}
\hline & $2009 / 2010$ & $2010 / 2011$ & $2011 / 2012$ & $2012 / 2013$ & $2013 / 2014$ \\
\hline BOL (\%) & 87,8 & 88,6 & 88,5 & 90,1 & 92,2 \\
\hline BBL (\%) & 12,1 & 11,3 & 11,5 & 9,8 & 7,8 \\
\hline & & & & & \\
\hline Instroom aantal & 91.063 & 89.616 & 88.067 & 86.688 & 88.368 \\
\hline
\end{tabular}

Bron: DU0, eigen bewerking ROA 


\section{Enquête onder scholen}

Om een evaluatie van het School Ex 2.0 programma uit te voeren is het van belang om van scholen informatie te ontvangen. Het betreft daarbij informatie over exit- en ombuigingsgesprekken in het voorjaar van 2013 alsmede in de voorafgaande jaren. Idealiter zou het laatste vergelijkbare data moeten kunnen produceren als de informatie over 2013. Met andere worden, idealiter zou je per school en per opleiding ook minimaal voor het schooljaar 2OII/2OI2 dienen te weten hoeveel exit- en ombuigingsgesprekken binnen elke opleiding hebben plaatsgevonden. We zijn ons echter bewust dat dit nauwelijks nog te achterhalen valt. Via een enquête onder scholen is daarom getracht informatie op het niveau van hoofdgroep ${ }^{2}$ (in het vervolg domein genoemd) te achterhalen op minimaal de volgende aspecten:

- Op welke manier heeft de school in 2013 exit- en ombuigingsgesprekken gevoerd? Het gaat hier om vragen zoals: 'wie heeft deze gespreken gevoerd?', 'was er een centrale opzet of niet?', 'met welke studenten werden gespreken gevoerd?'.

- Heeft de school in 2012 op eigen initiatief ombuigings- en/of exitgesprekken gevoerd en de plannen van hun gediplomeerden in kaart gebracht?

In december 2013 zijn hiervoor in totaal 69 scholen gevraagd om aan de enquête deel te nemen. De scholen is daarbij gevraagd om in principe per opleidingsdomein dat zij aanbieden informatie te verstrekken ${ }^{3}$. In totaal hebben 46 scholen op de aanvraag gereageerd en zijn na verdere controle de gegevens van 36 scholen voor de analyses gebruikt. De vragenlijsten van de resterende scholen bevatten op de kernvragen geen antwoorden of zijn niet terug te koppelen aan een bepaald onderwijsdomein. Tabel 2.2 laat zien dat de school-domein combinaties waarvan de enquête onder de scholen informatie biedt bijna 50\% van de populatie gediplomeerden omvat. Wat de verdeling tussen $\mathrm{MBO}-\mathrm{BOL}$ en MBO-BBL opleidingen betreft zien we dat zowel bij de school-domein combinaties waarvan informatie beschikbaar is als bij het MBO totaal 62\% van de gediplomeerden afkomstig is van een $\mathrm{MBO}-\mathrm{BOL}$ opleiding. Ook wat de verdeling van de gediplomeerden per opleidingsniveau betreft, zijn de deelnemende school-domein combinaties een perfecte afspiegeling van het $\mathrm{MBO}$.

Tabel 2.2

Kenmerken deelnemende school-domein combinaties (schooljaar 2012/2013)

\begin{tabular}{|l|r|r|}
\hline & Deelnemende school-domein combinaties & MBO Totaal \\
\hline Aantal gediplomeerden & 75.921 & 151.882 \\
\hline \% BOL & 62 & 62 \\
\hline \% Niveau 1 & 8 & 8 \\
\hline \% Niveau 2 & 29 & 29 \\
\hline \% Niveau 3 & 26 & 26 \\
\hline \% Niveau 4 & 37 & 37 \\
\hline
\end{tabular}

Bron: Enquête onder scholen

2. Zie voor een beschrijving van de onderliggende koppeltabel: www.kwalificatiesmbo.nl/crebo_overzichten.html.

3. De vragenlijst is op aanvraag bij de auteurs te ontvangen. 
In aanvulling op de bovenstaande enquête onder scholen die MBO-opleidingen aanbieden is in januari 2014 een tweetal enquêtes onder jongeren gehouden. Het betreft hierbij in eerste instantie een enquête onder jongeren die in het schooljaar 2012/2013 een diploma in het $\mathrm{MBO}$ hebben behaald en in tweede instantie een enquête onder jongeren die in het schooljaar 20I2/2013 een diploma in het VMBO hebben behaald en in oktober 2013 ingeschreven stonden in een opleiding van het MBO-BOL. ${ }^{4}$ Navolgend staan we kort stil bij de opzet van deze twee enquêtes, het verrichte veldwerk en de response op de enquête.

\section{Enquête onder recent gediplomeerden van het $M B O$}

In januari 2014 zijn in het kader van deze evaluatie 22.266 jongeren die in het schooljaar 20I2/2OI3 een MBO-diploma hebben behaald via een brief gevraagd om aan een enquête deel te nemen ${ }^{5}$. Hiervoor is via de bestanden van de DUO een aselecte steekproef onder de gediplomeerden van het MBO getrokken die op I oktober 2013 maximaal 30 jaar oud waren. De vragenlijst was gericht op het verzamelen van informatie betreffende de volgende aspecten:

- Welke intentie had de leerling begin 2013 met betrekking tot zijn nabije toekomst (dat wil zeggen wist de leerling begin 2013 al of hij/zij verder wilde gaan leren of zich op de arbeidsmarkt wilde aanbieden)

- Gesprekken op school over de toekomst: met wie, hoe vaak, met welke doelstelling, wat was de rol van School Ex enquêteformulier en wat is de uitkomst van de gesprekken (bijvoorbeeld alsnog verder gaan leren)

In totaal werden 3.942 vragenlijsten via internet ingevuld, wat neerkomt op een response van $18 \%$. Tabel 2.3 laat voor een aantal achtergrondkenmerken eventuele verschillen tussen de groep respondenten en de groep non-respondenten zien.

Tabel 2.3

Kenmerken van respondenten en non-respondenten van de vragenlijst onder MBO-gediplomeerden

\begin{tabular}{|l|r|r|}
\hline Gemiddelde leeftijd & Respondenten & Non-Respondenten \\
\hline \% Man & 21.3 & 21.7 \\
\hline \% MBO-BOL diploma & 43 & 52 \\
\hline \% Diploma op niveau 1/2 & 73 & 64 \\
\hline
\end{tabular}

Bron: Enquête onder MBO-gediplomeerden

De vergelijking in Tabel 2.3 laat zien dat onder de respondenten een lichte oververtegenwoordiging is van vrouwen, gediplomeerden van MBO-BOL en een lichte ondervertegenwoordiging van gediplomeerden van niveau $\mathrm{I} / 2$. We zullen hiermee in de latere analyses dan ook explicit rekening houden.

4. Aangezien jongeren die een opleiding in het MBO-BBL willen volgen in de regel voorafgaand aan de start van de opleiding in het bezit dienen te zijn van een contract bij een leerbedrijf, is ervoor gekozen om deze jongeren in het kader van dit onderzoek niet te benaderen.

5. Jongeren die op de eerste brief niet reageerden ontvingen eind januari 2014 een tweede brief. 
Enquête onder recent gediplomeerden van het $\mathrm{VMBO}$ die ingestroomd zijn in een $\mathrm{MBO}-\mathrm{BOL}$ opleiding

In januari 2014 zijn in het kader van deze evaluatie 20.239 jongeren die in het schooljaar 20I2-20I3 een VMBO diploma hebben behaald en in oktober 2013 ingeschreven stonden in een $\mathrm{MBO}-\mathrm{BOL}$ opleiding via een brief gevraagd om aan een enquête deel te nemen ${ }^{6}$. Hiervoor is via de bestanden van de Dienst Uitvoering Onderwijs (DUO) een aselecte steekproef onder de gediplomeerden van het VMBO getrokken die op I oktober 2013 ingeschreven stonden in een MBO-BOL opleiding. De vragenlijst was gericht op het verzamelen van informatie betreffende de volgende aspecten:

- Voor welke opleiding had de leerling zich willen inschrijven (dat wil zeggen over welke opleidingen twijfelde de leerling)

- Gesprekken op MBO school over opleidingskeuze: met wie, hoe vaak, met welke doelstelling, en wat is de uitkomst van de gesprekken (bijvoorbeeld bewustzijn van de arbeidsmarktperspectieven in de regio, en/of alsnog voor een andere opleiding gekozen)

In totaal werden 5.230 vragenlijsten via internet ingevuld, wat neerkomt op een response van $26 \%$. Tabel 2.4 laat op een aantal achtergrondkenmerken eventuele verschillen tussen de groep respondenten en de groep non-respondenten zien.

\section{Tabel 2.4}

Kenmerken van respondenten en non-respondenten van de vragenlijst onder VMBO-instroom in het $\mathrm{MBO}$

\begin{tabular}{|l|r|r|}
\hline \% Man & Respondenten & Non-Respondenten \\
\hline \% VMBO-TL diploma & 40 & 55 \\
\hline \% Ingestroomd in MBO niveau 1/2 & 48 & 49 \\
\hline
\end{tabular}

Bron: Enquête onder MBO-BOL instroom

De vergelijking laat zien dat ook wat dit databestand betreft een oververtegenwoordiging van vrouwen zichtbaar is en dat de response onder degenen die ingestroomd zijn in het $\mathrm{MBO}$ niveau $\mathrm{I} / 2$ lager ligt dan degenen die ingestroomd zijn in het $\mathrm{MBO}$ niveau 3/4.

\subsection{Het formele en het informele circuit van gesprekken}

Voordat we in hoofdstuk 3 en hoofdstuk 4 nader de effecten van exitgesprekken en ombuigingsgesprekken analyseren, is het belangrijk om vast te stellen wat de instrumenten, zoals hierboven gepresenteerd precies meten. Met andere worden, we dienen de vraag te stellen of de enquête onder de scholen hetzelfde meten als de enquête onder de jongeren. Achterliggende gedachte daarbij is dat de kans bestaat dat in scholen zowel een formeel

6. Jongeren die op de eerste brief niet reageerden ontvingen eind januari 2014 een tweede brief. 
circuit' en een 'informeel circuit' van exitgesprekken plaatsvindt. Het eerste circuit bestaat uit exitgesprekken die bijvoorbeeld door een school- dan wel domein- of locatie-breed protocol of aanpak geregeld zijn. Het tweede circuit bestaat uit gesprekken die vooral door docenten en mentoren gevoerd worden zonder dat daar een bepaald protocol of duidelijke interne afspraken voor bestaan en die misschien vaak niet eens geregistreerd worden. Indien het 'formele circuit' en het 'informele circuit' binnen scholen dan wel school-domein combinaties gescheiden verlopen, bestaat het gevaar dat de antwoorden op de enquête onder de scholen het eerste circuit meten, terwijl de antwoorden op basis van de enquête onder de recent gediplomeerden informatie over het tweede circuit opleveren.

\section{Exitgesprekken}

Ons startpunt is de enquête onder de scholen, en de vragen 'zijn in het schooljaar $2012 / 2013$ in uw domein exitgesprekken gevoerd?', 'Zijn in uw domein in voorgaande schooljaren exitgesprekken gevoerd?' en 'verschilt de procedure tussen de twee schooljaren?'. Op basis van deze drie vragen is het mogelijk de scholen (en de domeinen binnen de scholen) nader onder te verdelen in vier groepen:

a. Ervaren scholen met continue aanpak: Deze school-domein combinaties hebben zowel in 2012/2013 individuele exitgesprekken gevoerd als ook in voorgaande schooljaren (2009/20IO, 20IO/20II en/of 20II/20I2). De procedure en/of het percentage leerlingen dat exitgesprekken kreeg is daarbij niet veranderd tussen de twee jaren.

b. Ervaren scholen met nieuwe aanpak: Deze school-domein combinaties hebben zowel in 2012/20I3 individuele exitgesprekken gevoerd als ook in voorgaande schooljaren (2009/20IO, 2010/20II en/of 2011/2012). De procedure en/of het percentage leerlingen dat exitgesprekken kreeg is daarbij wel veranderd tussen de twee jaren.

c. Nieuwkomers: Deze school-domein combinaties hebben in 2012/20I3 individuele exitgesprekken gevoerd maar niet in voorgaande schooljaren (2009/2010, 20IO/2OII en/of 20II/2012).

d. Geen gesprekken: Deze school-domein combinaties hebben noch in 2012/2013, noch in voorgaande schooljaren (2009/20IO, 20IO/20II en/of 20II/20I2) exitgesprekken gevoerd.

Tabel 2.5 laat zien dat van 320 van de in totaal 685 school-domein combinaties in het $\mathrm{MBO}$ informatie bekend is via de enquête. 153 school-domein combinaties daarvan vallen onder de groep 'ervaren met continue aanpak', 53 onder de groep 'ervaren met nieuwe aanpak', 89 onder de groep 'nieuwkomers' en 25 onder de groep die ook in het schooljaar 20I2/2OI3 geen gesprekken hebben gevoerd.

Gezien het feit dat het School Ex 2.0 programma pas in het late voorjaar van 2013 van start ging, kan een tweetal hypotheses geformuleerd worden: 
a. 'Nieuwkomers' zijn later in het jaar met exitgesprekken begonnen dan de twee 'ervaren' groepen.

b. Het percentage (aanstaande) gediplomeerden van het schooljaar 20I2/20I3 waarmee de groep 'nieuwkomers' gesprekken heeft gevoerd is lager dan het percentage (aanstaande) gediplomeerden waarmee de 'ervaren' groepen gesprekken hebben gevoerd.

Tabel 2.5

Aantal school-domein combinaties voor elk van de onderscheiden groepen voor de exitgesprekken

\begin{tabular}{|l|r|r|r|r|r|r|}
\hline & $\begin{array}{r}\text { Ervaren met } \\
\text { continue aanpak }\end{array}$ & $\begin{array}{r}\text { Ervaren met } \\
\text { nieuwe aanpak }\end{array}$ & Nieuwkomer & Geen gesprekken & $\begin{array}{r}\text { Geen informatie } \\
\text { bekend }\end{array}$ & MB0 totaal \\
\hline Aantal & 153 & 53 & 89 & 25 & 365 & 685 \\
\hline$\%$ & $22 \%$ & $8 \%$ & $13 \%$ & $4 \%$ & $53 \%$ & $100 \%$ \\
\hline
\end{tabular}

Bron: Enquête onder scholen en DUO, eigen bewerking ROA

We testen deze twee hypotheses zowel via een interne validiteitstest (dat wil zeggen op basis van verschillende vragen gesteld in de vragenlijst onder de scholen) evenals via een externe validiteitstest (dat wil zeggen door een vergelijking van de antwoorden gegeven door de scholen met de antwoorden gegeven door de jongeren).

Beide hypotheses doorstaan de interne validiteitstest op basis van andere antwoorden gegeven door de scholen. Zo kan op basis van de antwoorden van de scholen een inschatting gemaakt worden van het aandeel jongeren waarmee gesprekken gevoerd is. Dit varieert van $33 \%$ in de groep 'nieuwkomers', en $48 \%$ in de groep 'ervaren met continue aanpak' tot $68 \%$ in de groep 'ervaren met nieuwe aanpak'. Eveneens kan vastgesteld worden dat de groep 'nieuwkomers' later met exitgesprekken begonnen zijn. Tot en met mei 2013 ligt het percentage school-domein combinaties binnen de groep nieuwkomers dat vermeldt dat er in een bepaalde maand exitgesprekken hebben plaatsgevonden (duidelijk) onder de IO\% om daarna in juni en juli explosief te stijgen naar respectievelijk $67 \%$ en zelfs $78 \%$. Ter vergelijking, in de 'ervaren' groepen ligt het aandeel vanaf januari aan al duidelijk boven de $20 \%$ en in het geval van de groep 'ervaren met nieuwe aanpak' in de regel zelfs duidelijk boven de 50\%.

De externe validiteitstest is ingewikkelder. Er bestaan immers geen directe data die de gegevens kunnen toetsen. Een mogelijke toets kan wel op basis van de enquête onder de recent gediplomeerden van het MBO plaatsvinden. We dienen er dan wel rekening mee te houden dat deze data hun eigen problemen kennen. Zo bestaat het gevaar dat recent gediplomeerden die een exitgesprek hebben gehad vaker responderen dan recent gediplomeerden zonder exitgesprek. Dit kan bijvoorbeeld het geval zijn omdat zij positiever terugdenken aan de opleiding en/of school of omdat ze dankzij het exitgesprek een succesvollere transitie naar het vervolgonderwijs of de arbeidsmarkt achter de rug hebben. Een te simpele vergelijking tussen het percentage respondenten dat vermeldt een exitgesprek gehad te hebben met het percentage zoals vermeld door de scholen kan 
daardoor een vertekend beeld geven. ${ }^{7}$ Wat wel aannemelijk is, is dat er wat dit punt betreft geen verschillen in response patronen tussen de onderscheiden groepen van school-domein combinaties bestaat. Dat wil zeggen dat een eventuele positieve response bias van gediplomeerden die een exitgesprek hebben gehad in principe voor alle vier onderscheiden groepen van school-domein combinaties zal gelden. Tabel 2.6 vergelijkt daarom tussen de groepen het percentage respondenten op basis van de steekproef onder de gediplomeerden dat vermeldt een exitgesprek gehad te hebben met het percentage gediplomeerden dat volgens de scholen een gesprek gehad heeft. Voor twee van de drie groepen komt een aanzienlijk verschil naar voren. Terwijl het aandeel dat een exitgesprek heeft gehad volgens de scholen zo'n $33 \%$ ('nieuwkomers') of $48 \%$ is ('ervaren met continue aanpak'), vermeldt in beide groepen $72 \%-73 \%$ van de gediplomeerden dat zij een exitgesprek hebben gehad. In de groep 'ervaren met nieuwe aanpak' komt het aandeel op basis van de twee aparte bevragingen echter bijna perfect overeen. ${ }^{8}$ Ondanks dat de uitkomsten van de enquête onder de jongeren zelf eventueel een positieve response bias kent richting jongeren die een exitgesprek hebben gehad, kan deze bias niet als verklaring dienen waarom zeker in de groep 'nieuwkomers' het verschil zodanig hoger ligt dan in de andere twee groepen.

Tabel 2.6

Aandeel gesprekken volgens scholen en volgens gediplomeerden (\%)

\begin{tabular}{|l|r|r|r|} 
& $\begin{array}{r}\text { Ervaren met continue } \\
\text { aanpak }\end{array}$ & $\begin{array}{r}\text { Ervaren met nieuwe } \\
\text { aanpak }\end{array}$ & $\begin{array}{r}\text { Nieuwkomer } \\
\text { Op basis van gediplomeerden enquête }\end{array} \quad 73$ \\
\hline Op basis van scholen enquête & & 67 & 72 \\
\hline Verschil & 48 & 68 & 33 \\
\hline
\end{tabular}

${ }^{1}$ Dit is berekend door per antwoord categorie het gemiddelde te nemen (bijvoorbeeld 5\% voor de klasse 0-10\%) en dan per groep een gewogen gemiddelde te berekenen op basis van het aantal gediplomeerden dat volgens de registerdata van DUO tot een bepaalde schooldomein combinatie behoort.

Bron: Enquête onder MBO-gediplomeerden en enquête onder scholen

Voordat mogelijke verklaringen van deze uitkomst nader besproken en de consequenties voor de voorliggende evaluatie geanalyseerd worden, is het interessant om direct ook de tweede hypothese te testen. Hiervoor presenteren we in Figuur 2.2a en 2.2b per kalendermaand de verdeling tussen de drie groepen van school-domein combinaties indien zij melden in een bepaalde maand gesprekken te hebben gevoerd. Wat de enquête onder de scholen betreft, heeft deze informatie betrekking op de vraag of er in een bepaalde maand

7. De lezer dient er daarnaast rekening mee te houden dat de respondenten weliswaar afkomstig zijn van beide leerwegen, maar dat zij op moment van behalen van het diploma maximaal 30 jaar oud zijn. Zeker wat het MBO-BBL betreft is daarmee een relatief grote groep van gediplomeerden op voorhand niet in de steekproef opgenomen. Daarnaast dient er rekening mee gehouden te worden dat het aantal respondenten (bijna 400o) wel een betrouwbaar landelijk beeld kan bieden, maar dat er per school-domein combinatie binnen een van de vier onderscheiden groepen te weinig respondenten zijn om op dit niveau betrouwbare uitspraken te doen. Wel zijn er voldoende respondenten om voor elk van de vier groepen apart betrouwbare uitspraken te doen.

8. Voor de groep 'geen gesprekken' is het percentage recent gediplomeerden dat vermeldt een exitgesprek gehad te hebben met zo'n $70 \%$ op een vergelijkbaar niveau met de andere drie groepen. 
exitgesprekken gevoerd zijn. Wat de enquête onder de gediplomeerden betreft, heeft deze informatie betrekking op de vraag of de (aanstaande) gediplomeerden aangeven in een bepaalde maand een exitgesprek te hebben gehad. Aangezien zowel in de data afkomstig van de scholen als in de data afkomstig van de jongeren het absolute aantal schooldomein combinaties dan wel het absolute aantal jongeren dat tot een van de drie groepen behoort niet evenredig verdeeld is, presenteren we in beide figuren aan de linker kant de algemene verdeling tussen de drie groepen.

Figuur 2.2a laat op basis van de enquête onder de scholen het eerder al genoemde beeld zien. Het percentage 'nieuwkomers' is tot en met mei 2013 marginaal vertegenwoordigd bij exitgesprekken en ligt relatief gezien duidelijk onder het percentage zoals verwacht op basis van de algemene verdeling aan de linker kant. In juni komt de verdeling relatief goed overeen met de algemene verdeling en in juli, op moment waar de 'ervaren' groepen relatief minder vaak exitgesprekken melden, is het aandeel 'nieuwkomers' zelfs relatief hoog te noemen.

\section{Figuur 2.2a}

Verdeling van School-domein combinaties, indien in een bepaalde maand gesprekken hebben plaatsgevonden: scholen enquête

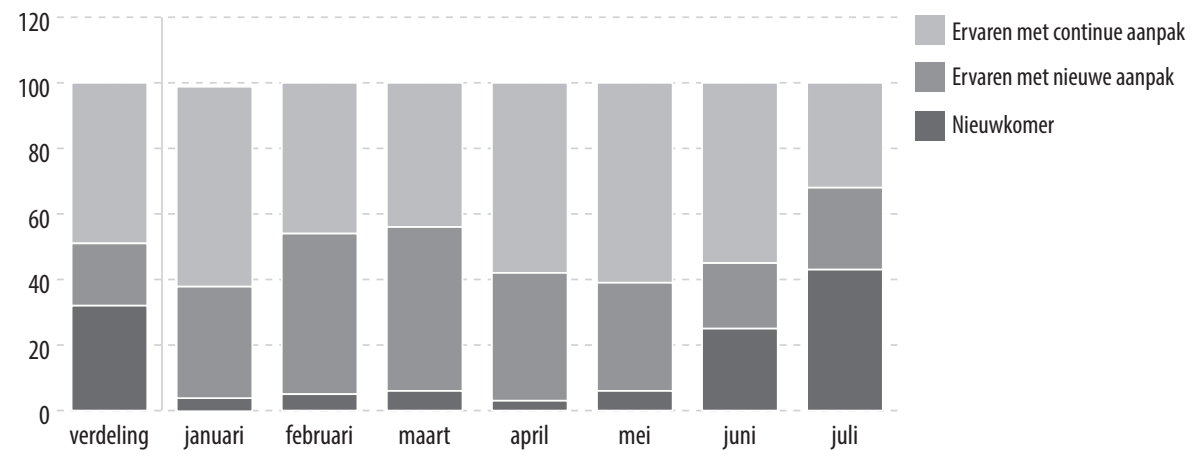

Bron: Enquête onder scholen

Figuur 2.2b laat zien dat de timing van exitgesprekken op basis van de enquête onder recent gediplomeerden niet overeen komt met de timing zoals vermeld door de scholen. De figuur laat namelijk zien dat de verdeling op basis van de gesprekken in alle maanden relatief goed correspondeert met de algemene verdeling gepresenteerd aan de linker kant. Met andere woorden, volgens de gediplomeerden zijn ook binnen de groep 'nieuwkomers' vanaf begin van het jaar 2013 met regelmaat exitgesprekken gevoerd.

Nadere analyses van de data afkomstig van de jongeren laat daarnaast zien dat jongeren in de groep 'nieuwkomers' die aan het begin van het schooljaar 2012/2013 (september tot december 20I2) hun diploma behaald hebben, eveneens in vergelijkbare mate exitgesprekken hebben gehad als jongeren die hun diploma in de tweede helft van het schooljaar hebben behaald. 


\section{Figuur 2.2b}

Verdeling van School-domein combinaties, indien in een bepaalde maand gesprekken hebben plaatsgevonden: gediplomeerden enquête

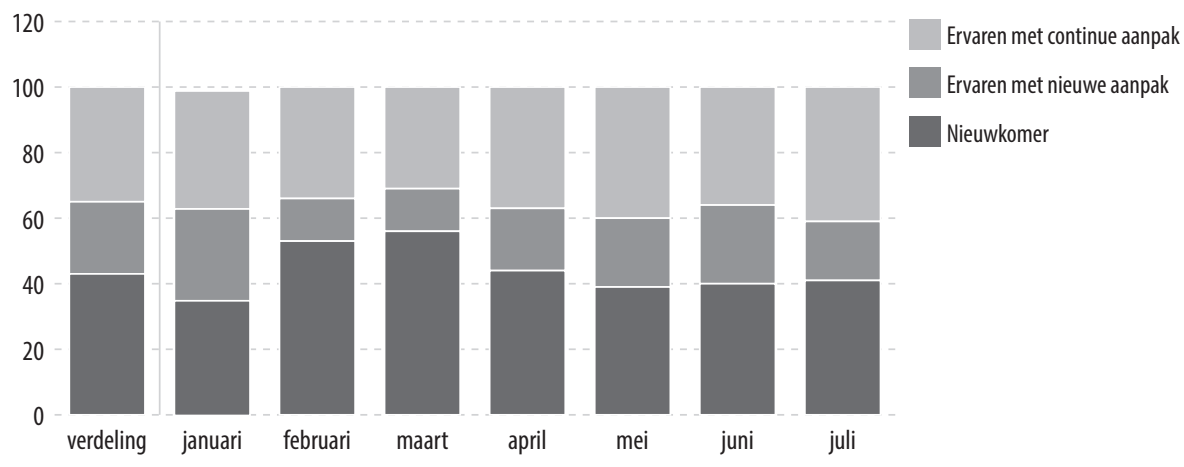

Bron: Enquête onder MB0-gediplomeerden

Wat kan de reden zijn voor deze aanzienlijke verschillen tussen de uitkomsten op basis van de enquête onder de scholen en de uitkomsten op basis van de enquête onder de jongeren en wat zijn de consequenties voor de voorliggende evaluatie van het School Ex 2.0 programma?

Gezien zowel de scholen als de jongeren geen profijt kunnen behalen door bewust aan te geven dat gesprekken in een bepaalde maand hebben plaatsgevonden terwijl ze weten dat dat in werkelijkheid niet zo was, dienen de oorzaken in een andere hoek gezocht te worden. Een mogelijke verklaring kan zijn dat er inderdaad een verschil bestaat tussen wat men het 'formele circuit' en het 'informele circuit' van exitgesprekken kan noemen, zoals eerder gemeld. De data afkomstig van de scholen en de data afkomstig van de jongeren geven verdere indicaties voor een dergelijke tweedeling:

- Ten eerste komt in de resultaten afkomstig van de scholen naar voren dat vooral bij de groep 'ervaren met nieuwe aanpak' het aandeel dat een protocol kent voor de exitgesprekken hoog ligt. In 46\% van de groep 'ervaren' school-domein combinaties wordt met een protocol voor de exitgesprekken gewerkt, wat bijna twee keer zo hoog is als in de twee andere groepen. Dit kan een verklaring zijn waarom precies in deze groep 'ervarenen' het verschil tussen het aandeel exitgesprekken dat door de jongeren vermeld wordt en het aandeel dat door de scholen vermeld wordt bijna nul is.

- Ten tweede laat een vergelijking van de antwoorden van de scholen en de antwoorden van de recent gediplomeerden op een andere punt een aanvullend verschil zien, namelijk op de vraag 'wie heeft de exitgesprekken gevoerd' (o.b.v. enquête onder scholen) en 'met wie heb je een exitgesprek gehad' (o.b.v. enquête onder gediplomeerden). In beide gevallen konden respondenten meerdere antwoorden geven. Een vergelijking van de antwoorden (zie Tabel 2.7) ${ }^{9}$ laat

9. In de tabel zijn alleen de antwoord categorieën opgenomen die in beide vragenlijsten identiek zijn. 
zien dat SLB-ers in alle drie onderscheiden groepen in de antwoorden van de scholen het vaakst genoemd worden. In de antwoorden van de gediplomeerden komen de SLB-ers echter op een tweede of zelfs op een derde plaats. Op de eerste plaats komt bij de jongeren in alle drie groepen de mentor te staan, in de regel gevolgd door de docenten. Dit bevestigt het beeld van een mogelijk verschil in het 'formele' en het 'informele' circuit: in de praktijk zijn het de mentoren/docenten die (waarschijnlijk op informele basis) exitgesprekken voeren, terwijl het volgens de scholen zelf, formeel gezien, de SLB'ers zijn die dit (horen te) doen.

Tabel 2.7

Wie heeft de exitgesprekken gevoerd / met wie heb je het exitgesprek gehad (\%, meerdere antwoorden mogelijk)

\begin{tabular}{|l|r|r|r|r|r|r|}
\hline & \multicolumn{2}{|c|}{ Ervaren met continue aanpak } & \multicolumn{2}{|c|}{ Ervaren met nieuwe aanpak } & \multicolumn{2}{|c|}{ Nieuwkomer } \\
& Scholen & Gediplomeerden & Scholen & Gediplomeerden & Scholen & Gediplomeerden \\
\hline Docenten & 15 & 38 & 35 & 39 & 20 & 34 \\
\hline Mentor & 24 & 57 & 14 & 55 & 30 & 61 \\
\hline SLB'er & 62 & 35 & 53 & 31 & 57 & 38 \\
\hline lemand anders & 45 & 6 & 18 & 3 & 38 & 4 \\
\hline
\end{tabular}

Bron: Enquête onder scholen en enquête onder MB0-gediplomeerden

Op basis van de bovenstaande analyses dienen we dan ook de volgende twee conclusies te trekken die van centraal belang zijn voor onze analyses in Hoofdstuk 3:

a. Analyses op basis van de enquête onder de scholen geven inzicht in de vraag wat het effect van een formeel circuit is op het doorstroomgedrag van de jongeren.

b. Analyses op basis van de enquête onder de jongeren geven inzicht in de vraag wat het effect van het informele circuit is op het doorstroomgedrag van de jongeren.

\section{Ombuigingsgesprekken}

Vergelijkbaar met onze discussie over de exitgesprekken dienen we er ook met betrekking tot de ombuigingsgesprekken rekening mee te houden dat er een verschil kan zijn tussen de informatie afkomstig van de scholen (het 'formele circuit') en de informatie afkomstig van de jongeren (het 'informele circuit'). Daarnaast is er nog een tweede, meer cruciaal verschil tussen deze twee informatiebronnen. Dit heeft ermee te maken dat ombuigingsgesprekken in de regel plaats zullen vinden in de vorm van een intake- of studiekeuzegesprek, maar dat niet ieder studiekeuzegesprek een ombuigingsgesprek hoeft te zijn. Dit geldt zeker in het geval van aanmeldingen bij opleidingen met goede arbeidsmarktperspectieven. Scholen zijn daarom expliciet gevraagd om informatie te leveren over ombuigingsgesprekken, waarbij in de vragenlijst onderstaande definitie van ombuigingsgesprekken is gegeven. 
Box 2.1

Definitie van ombuigingsgesprekken zoals gepresenteerd in de vragenlijst onder scholen

Met ombuigingsgesprekken bedoelen we gesprekken met VMBO-uitstromers die zich aanmelden voor een $\mathrm{MBO}$-opleiding met weinig perspectief, met als doel ze om te buigen naar een beroep met meer perspectief.

Jongeren zijn daarentegen niet expliciet gevraagd om informatie te leveren over ombuigingsgesprekken. Zij zijn gevraagd om in het algemeen informatie te leveren over de vraag of zij hun studiekeuze met de $\mathrm{MBO}$-school hebben besproken. Er dient daarom rekening mee gehouden te worden dat de informatie vanuit de vragenlijst onder de jongeren meer in het algemeen betrekking heeft op studiekeuzegesprekken.

Als jongeren overgehaald kunnen worden om een andere studiekeuze te maken, zal die studiewissel daarnaast in de regel binnen een bepaalde sector of domein plaatsvinden, en minder vaak tussen sectoren of domeinen. Dat betekent dat het ombuigen van jongeren doorgaans zal plaatsvinden op het niveau van een opleiding en niet op domeinniveau. We hebben getracht om hiermee in de vragenlijst onder de scholen (ingevuld per domein binnen een school) rekening te houden door expliciet te vragen naar de opleidingen waar ombuigingsgesprekken hebben plaatsgevonden. Desondanks is de ontvangen informatie op dit punt onvoldoende om betrouwbare uitspraken op het niveau van opleidingen te doen.

Op basis van deze punten dienen we dan ook de volgende conclusie te trekken die van centraal belang is voor onze analyses in Hoofdstuk 4:

De analyses op in hoofdstuk 4 zullen betrekking hebben op de enquête onder de jongeren en daarmee alleen op de invloed van het informele circuit van ombuigingsgesprekken dat via de algemene intake-/studiekeuzegesprekken plaatsvindt. 


\section{3 \\ EXITGESPREKKEN}

De doelstelling van de voorliggende evaluatie is om vast te stellen of de invoering van het School Ex 2.o programma, en daarbij specifiek de Exitgesprekken en Ombuigingsgesprekken, de gewenste effecten heeft bereikt. In dit hoofdstuk staan we stil bij de Exitgesprekken. De centrale vraag is of deze inderdaad tot een hogere doorstroom naar het vervolgonderwijs hebben geleid en daarom als korte termijn middel voor het terugdringen van de jeugdwerkloosheid gezien kunnen worden (zie ook Schema 3.I). ${ }^{\text {Io }}$ De opzet van het hoofdstuk is daarbij tweedelig.

In het eerste gedeelte (paragraaf 3.I) analyseren we op het niveau van domeinen binnen scholen wat het algemene 'treatment' effect is van het voeren van exitgesprekken op het percentage gediplomeerden dat gaat doorleren. In hoofdstuk 2 hebben we laten zien dat dit een evaluatie van het 'formele circuit' van exitgesprekken betreft en de enquête onder de scholen ons toestaat om hierbij een vergelijking te maken tussen scholen die in het schooljaar 2012/2013 gestart zijn met het voeren van exitgesprekken en scholen die hiermee al eerder gestart zijn. We maken hierbij gebruik van zogenaamde difference-indifference analyses.

In het tweede gedeelte van het hoofdstuk (paragraaf 3.2) staan we stil bij de ervaringen van de jongeren zelf (het informele circuit) en de vragen zoals 'welke groep jongeren heeft een exitgesprek gehad?', 'zijn ze naar eigen zeggen door het exitgesprek beïnvloed?' en zo ja, 'hoe hebben ze hun keuze aangepast?'. Paragraaf 3.2 is daarmee een evaluatie van het informele circuit van exitgesprekken. De doelstelling van deze paragraaf is dan ook om meer in het algemeen de waarde van exitgesprekken vast te stellen.

IO. Zie bijlage I voor een schematisch overzicht van de beleidstheorie van het School Ex 2.0 programma. 


\section{Schema 3.1}

Conceptueel model van de beleidstheorie van Exitgesprekken

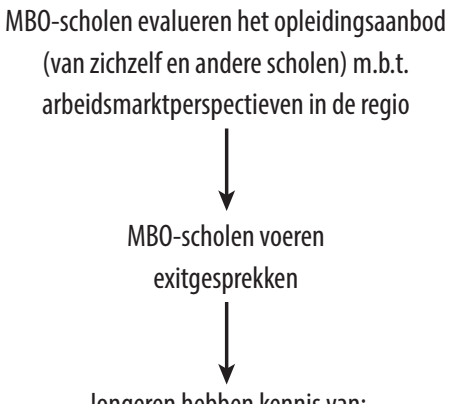

Jongeren hebben kennis van:

arbeidsmarktperspectieven van hun afgeronde opleiding arbeidsmarktperspectieven van mogelijke vervolgopleidingen

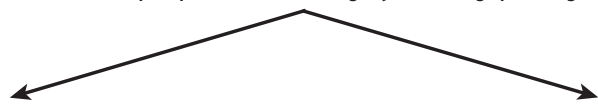

Het percentage jongeren dat ervoor kiest de arbeidsmarkt Het percentage jongeren dat ervoor kiest door te studeren (met kennis van te betreden neemt af

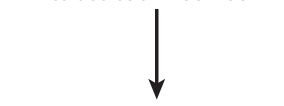
arbeidsmarktperspectieven van mogelijke vervolgopleidingen) neemt toe

\section{Jeugdwerkloosheid korte termijn daalt}

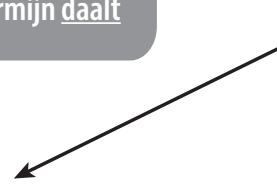

Het percentage aanmeldingen voor vervolgopleidingen met slechte arbeidsmarktperspectieven neemt af<smiles></smiles>

Het percentage afgestudeerden van vervolgopleidingen met slechte arbeidsmarktperspectieven neemt af

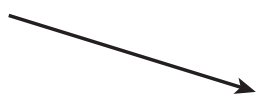

Het percentage aanmeldingen voor vervolgopleidingen met goede arbeidsmarktperspectieven neemt toe

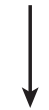

Het percentage afgestudeerden van vervolgopleidingen met goede arbeidsmarktperspectieven neemt toe 


\subsection{Evaluatie van het formele circuit van exitgesprekken}

Om het algemene 'treatment' effect vast te stellen starten we onze analyses op basis van de uitkomsten afkomstig van de enquête onder de scholen. ${ }^{\text {II }}$ We focussen hierbij in eerste instantie op de vragen 'zijn in het schooljaar 2012/2013 in uw domein exitgesprekken gevoerd?', 'zijn in uw domein in voorgaande schooljaren exitgesprekken gevoerd?' en 'verschilt de procedure tussen de twee schooljaren?'. Op basis van deze drie vragen is het mogelijk de scholen (en de domeinen binnen de scholen) nader onder te verdelen in vier groepen:

a. Ervaren scholen met continue aanpak: Deze school-domein combinaties hebben zowel in 2012/2OI3 individuele exitgesprekken gevoerd als ook in voorgaande schooljaren (2009/20IO, 2010/20II en/of 20II/20I2). De procedure en/of het percentage leerlingen dat exitgesprekken kreeg is daarbij niet veranderd tussen de twee jaren.

b. Ervaren scholen met nieuwe aanpak: Deze school-domein combinaties hebben zowel in 2012/2013 individuele exitgesprekken gevoerd als ook in voorgaande schooljaren (2009/20IO, 20I0/20II en/of 20II/20I2). De procedure en/of het percentage leerlingen dat exitgesprekken kreeg is daarbij wel veranderd tussen de twee jaren.

c. Nieuwkomers: Deze school-domein combinaties hebben in 2012/2013 individuele exitgesprekken gevoerd maar niet in voorgaande schooljaren (2009/20Io, 20Io/2OII en/of 20II/20I2).

d. Geen gesprekken: Deze school-domein combinaties hebben noch in 2012/2013, noch in voorgaande schooljaren (2009/20IO, 20IO/20II en/of 20II/2012) exitgesprekken gevoerd.

Zoals eerder vermeld kan op basis van de enquête die afgenomen is onder de scholen deze informatie voor 360 van de 685 school-domein combinaties vastgesteld worden. Tabel 3.I laat per groep het aantal domeinen alsmede het aandeel van de domein in het totale $\mathrm{MBO}$ zien.

Tabel 3.1

Aantal school-domein combinaties voor elk van de onderscheiden groepen voor de exitgesprekken

\begin{tabular}{|l|r|r|r|r|r|r|}
\hline & $\begin{array}{r}\text { Ervaren met } \\
\text { continue aanpak }\end{array}$ & $\begin{array}{r}\text { Ervaren met } \\
\text { nieuwe aanpak }\end{array}$ & Nieuwkomer & $\begin{array}{r}\text { Geen } \\
\text { gesprekken }\end{array}$ & $\begin{array}{r}\text { Geen informatie } \\
\text { bekend }\end{array}$ & MB0 totaal \\
\hline Aantal & 153 & 53 & 89 & 25 & 365 & 685 \\
\hline$\%$ & $22 \%$ & $8 \%$ & $13 \%$ & $4 \%$ & $53 \%$ & $100 \%$ \\
\hline
\end{tabular}

Bron: Enquête onder scholen en DU0, eigen bewerking ROA

Om de vier onderscheiden groepen verder te karakteriseren, laat Tabel 3.2 per onderscheiden groep een aantal achtergrondkenmerken zien van de populatie gediplomeerden van het schooljaar 2012/2013. Daarnaast presenteren we de cijfers ook voor de totale groep $\mathrm{MBO}$-gediplomeerden van het schooljaar 2012/2013.

II. Voor een verantwoording van deze enquête en de uitkomsten hiervan, zie hoofdstuk 2: Data en instrumenten. 
Tabel 3.2 laat zien dat de school-domein combinaties waarvan de enquête onder de scholen informatie biedt, zo'n 50\% van de populatie $\mathrm{MBO}$ gediplomeerden omvat. Met andere woorden: ongeveer de helft van de $\mathrm{MBO}$-gediplomeerden van het schooljaar 2012/20I3 heeft een opleiding afgerond binnen een domein van een school dat heeft meegedaan aan dit onderzoek. Het percentage gediplomeerden dat in het schooljaar 2012/2013 een MBO-BOL opleiding heeft afgerond is daarbij met $52 \%$ het laagst in de groep 'ervaren met continue aanpak' en bovengemiddeld hoog in de groep 'geen gesprekken'. In de laatste groep zijn daarnaast niveau I gediplomeerden duidelijk ondervertegenwoordigd. Tot slot valt op dat ook het percentage gediplomeerden van niet-westerse afkomst aanzienlijk verschilt tussen de vier groepen van interesse. Dit is in lijn met het feit dat de groep 'nieuwkomers' oververtegenwoordigd is in het westen van het land. We dienen bij de analyses later hiermee rekening te houden.

Tabel 3.2

Kenmerken van de populatie gediplomeerden van het schooljaar 2012/2013

\begin{tabular}{|l|r|r|r|r|r|} 
& $\begin{array}{r}\text { Ervaren met } \\
\text { continue aanpak }\end{array}$ & $\begin{array}{r}\text { Ervaren met } \\
\text { nieuwe aanpak }\end{array}$ & Nieuwkomer & $\begin{array}{r}\text { Geen } \\
\text { gesprekken }\end{array}$ & MBO Totaal \\
\hline Aantal gediplomeerden & 26.650 & 13.316 & 33.063 & 2.892 & 151.882 \\
\hline \% BOL & $(17.5 \%)$ & $(8.8 \%)$ & $(21.8 \%)$ & $(1.9 \%)$ & $(100 \%)$ \\
\hline \% Niveau 1 & 52,4 & 66,3 & 66,7 & 81,5 & 62,3 \\
\hline \% Niveau 2 & 6,9 & 6,1 & 9,0 & 2,7 & 8,3 \\
\hline \% Niveau 3 & 32,7 & 24,4 & 29,0 & 26,5 & 28,8 \\
\hline \% Niveau 4 & 26,4 & 31,9 & 23,7 & 22,2 & 25,9 \\
\hline \% Niet westerse allochtonen & 34,1 & 37,6 & 38,3 & 48,6 & 37,0 \\
\hline
\end{tabular}

Bron: DU0, eigen bewerking ROA

Naast de algemene achtergrondkenmerken is het belangrijk om direct ook naar de verdeling qua domeinen te kijken (zie Tabel 3.3). Gezien de relatief kleine omvang van de groep 'geen gesprekken' is het niet verrassend dat niet alle domeinen in deze groep vertegenwoordigd zijn en daarnaast een aantal relatief kleine domeinen een oververtegenwoordiging kennen.

\subsubsection{Het algemene treatment effect van exitgesprekken}

Wat is het algemene treatment effect van het onderdeel 'Exitgesprekken' van de invoering van het School Ex 2.0 programma als we ons concentreren op het 'formele circuit'?. Om dit nader te analyseren is een set van zogenaamde 'Difference-in-Difference' analyses (zie Box 3.I voor achtergrondinformatie over deze type analyses) uitgevoerd op basis van de uitkomsten van de enquête onder de scholen die gekoppeld is aan registerdata van DUO.

Het gekoppelde databestand bevat op het niveau van de school-domein combinaties aan de ene kant informatie afkomstig van de registerdata van DUO: 
- Percentage gediplomeerden van het schooljaar 20II/20I2 en het schooljaar $2012 / 2013$ dat doorgestroomd is naar een vervolgopleiding

- Samenstelling van de gediplomeerde uitstroom per school-domein combinaties: niveau van opleiding, leerweg, leeftijd van gediplomeerden, etniciteit van gediplomeerden, woonplaats van gediplomeerden etc.

Daarnaast bevat het gekoppelde databestand de informatie afkomstig van de enquête onder de scholen (o.a. de informatie betreffende de vier groepen die we eerder hebben onderscheiden).

Tabel 3.3

Verdeling van domeinen binnen de onderscheiden groepen van exitgesprekken (\%)

\begin{tabular}{|c|c|c|c|c|c|}
\hline & $\begin{array}{r}\text { Ervaren met } \\
\text { continue } \\
\text { aanpak }\end{array}$ & $\begin{array}{r}\text { Ervaren met } \\
\text { nieuwe } \\
\text { aanpak }\end{array}$ & $\begin{array}{l}\text { Nieuw- } \\
\text { komer }\end{array}$ & $\begin{array}{r}\text { Geen } \\
\text { gesprekken }\end{array}$ & $\begin{array}{r}\text { MBO } \\
\text { Totaal }\end{array}$ \\
\hline Afbouw, hout en onderhoud & 0,6 & 1,7 & 1,3 & 3,9 & 1,8 \\
\hline AKA & 4,5 & 3,8 & 4,1 & 0,0 & 5,0 \\
\hline Ambacht, laboratorium en gezondheidstechniek & 0,9 & 0,5 & 0,2 & 3,0 & 0,9 \\
\hline Bouw en infra & 3,6 & 4,0 & 2,8 & 4,4 & 3,3 \\
\hline Economie en administratie & 7,3 & 15,3 & 12,7 & 11,4 & 10,5 \\
\hline Handel en ondernemerschap & 13,7 & 8,4 & 8,4 & 0,0 & 8,3 \\
\hline Horeca en bakkerij & 6,5 & 4,9 & 5,2 & 12,6 & 5,5 \\
\hline Informatie en communicatietechnologie & 2,7 & 5,7 & 3,2 & 3,7 & 3,5 \\
\hline Media en vormgeving & 1,6 & 1,8 & 3,9 & 32,4 & 3,2 \\
\hline Mobiliteit en voertuigen & 3,9 & 3,1 & 1,9 & 5,9 & 2,6 \\
\hline Techniek en procesindustrie & 10,6 & 5,9 & 5,9 & 0,0 & 8,8 \\
\hline Toerisme en recreatie & 1,7 & 5,0 & 1,4 & 5,0 & 2,3 \\
\hline Transport, scheepvaart en logistiek & 8,5 & 3,4 & 6,0 & 3,9 & 5,0 \\
\hline Uiterlijke verzorging & 4,9 & 1,6 & 2,3 & 7,6 & 2,8 \\
\hline Veiligheid en sport & 4,9 & 4,3 & 5,6 & 6,2 & 4,7 \\
\hline Voedsel, natuur en leefomgeving & 2,6 & 0,0 & 3,5 & 0,0 & 5,6 \\
\hline Zorg en welzijn & 21,5 & 30,6 & 31,5 & 0,0 & 26,2 \\
\hline Totaal & $100 \%$ & $100 \%$ & $100 \%$ & $100 \%$ & $100 \%$ \\
\hline
\end{tabular}

Bron: DUO, eigen bewerking ROA

Via de 'Difference-in-Difference' analyses wordt getracht om een drietal kern coëfficiënten te schatten:

- De jaardummy: Deze coëfficiënt tracht om eventuele algemene verschillen tussen de schooljaren 20II/20I2 en 2012/2013 die voor alle school-domein combinaties gelden op te pikken.

- De treatment dummy: Deze coëfficiënt pikt eventuele algemene verschillen in het aandeel dat doorstroomt tussen de 'treatment groep' en de 'controle groep' op. Daarbij wordt verondersteld dat deze verschillen zowel voor het schooljaar 2OII/2OI2 alsmede voor het schooljaar 20I2/20I3 gelden. 
Box 3.1

Difference in difference

Difference in difference (DiD) is een statistische techniek om causale verbanden te achterhalen van bepaaldegebeurtenissen of beleidsveranderingen. DiDmaakt gebruikvan verschillen tussengroepen over tijd die wel of niet bloot hebben gestaan aan deze gebeurtenissen of beleidsveranderingen. Wanneer beleid verandert voor de gehele populatie is het onmogelijk om te zien of dit beleid een effect heeft gehad, aangezien de gehele populatie heeft blootgestaan aan dezelfde behandeling. Er is in andere woorden geen counterfactuele situatie waarmee de daadwerkelijke situatie vergeleken kan worden. DiD maakt het mogelijk om toch een counterfactuele situatie te gebruiken door de populatie die heeft bloot gestaan aan een beleidsverandering te vergelijken met een soortgelijke populatie die niet hieraan bloot gestaan heeft. Om te controleren voor eventuele veranderingen die beide populaties op eenzelfde manier over tijd ondergaan, worden de twee populaties op twee punten in tijd gemeten: toen beide populaties nog niet behandeld waren en toen een van de populaties behandeld was. Voorwaarde is wel dat de verschillen tussen de twee populaties, als er geen beleidsverandering had opgetreden, hetzelfde zouden zijn gebleven. Dit is een zwakkere assumptie dan de assumptie dat de twee populaties voor de behandeling in alles hetzelfde waren. Het enige wat nodig is, is dat het verschil tussen verschillen in de twee populaties voor en na de behandeling alleen het effect weergeeft van de verandering in beleid. Dit verklaart ook de naam van de techniek omdat er twee verschillen (het normale verschil tussen de twee populaties voor de beleidsverandering, en het normale verschil plus het verschil door de beleidsverandering na de beleidsverandering) van elkaar worden afgetrokken om een causaal verband over te houden. Om te zorgen dat andere verschillen tussen de twee populaties gelijk zijn gebleven over tijd worden vaak vooraf vergelijkbare populaties vergeleken en wordt voor relevante aspecten geloofwaardig gemaakt dat er niets anders het verschil in verschil kan verklaren.

Eind jaren '80 werd deze methode voor het eerst toegepast binnen de economie. Een paar van de eerste papers waren Ashenfelter en Card (1985), Card en Sullivan (1988) en Card (1990). Ashenfelter en Card (1985) en Card en Sullivan (1988) analyseren beleid in de Verenigde Staten waarbij werklozen een training kregen aangeboden om hun kans op werk te vergroten. Card (1990) analyseert het effect van een groot aandeel migranten werkers op de kans op werk voor autochtonen door gebruik te maken van een grote instroom migranten vanuit Cuba naar Miami, en dit te vergelijken met soortgelijke steden zonder instroom van migranten. Sinds de jaren' 90 is DiD nog vele malen toegepast binnen de economie en momenteel behoort het tot het standaard arsenaal van statistische technieken om causale verbanden te achterhalen.

Referenties:

Ashenfelter, Orley en Card, David (1985) Using the Longitudinal Structure of Earnings to Estimate the Effect of Training Programs. The Review of Economics and Statistics, 67(4), pp. 648-60.

Card, David en Sullivan, Daniel (1988), Measuring the Effect of Subsidized Training Programs on Movements In and Out of Employment, Econometrica, Vol. 56, No. 3, pp. 497-530.

Card, David (1990) The Impact of the Mariel Boatlift on the Miami Labor Market. Industrial and Labor Relations Review, 43(2), pp. 245-257.

Card, David en Krueger, Alan B. (1994) Minimum Wages and Employment: A Case Study of the FastFood Industry in New Jersey and Pennsylvania. American Economic Review, 84(4), pp. 772-793.

- De interactie tussen de jaardummy en de treatment dummy: Deze coëfficiënt meet of er in de verandering tussen het schooljaar 20II/20I2 en het schooljaar 20I2/20I3 wat het aandeel betreft dat doorstroomt naar een vervolgopleiding een verschillende ontwikkeling plaatsvindt tussen de groep die het treatment heeft ontvangen en de groep die dat niet heeft ontvangen. 
Voor de evaluatie is daarbij de 'interactie dummy' van belang. Een positief significante 'interactie dummy' is een indicatie dat het algemene treatment effect aanwezig is en de invoering van het School Ex 2.o programma inderdaad tot een significante verhoging van het aandeel in de doorstroom heeft geleid.

Voor het uitvoeren van 'Difference-in-Difference' analyses is het centraal om naast de 'treatment groep' (dat wil zeggen de groep die het treatment heeft ondergaan) zogenaamde controle groepen te definiëren. In ons geval betreft de treatment groep de groep die we als 'nieuwkomers' hebben getypeerd. Wat de controle groep betreft, zijn er verschillende opties:

- Groep 'ervaren met continue aanpak'

- Groep 'geen gesprekken’

- Groep 'ervaren met continue aanpak + ervaren met nieuwe aanpak'

Aangezien er op voorhand niet direct een voorkeur voor een bepaalde controle groep aanwezig is, is ervoor gekozen om de 'Difference-in-Difference' analyses met verschillende controle groepen uit te voeren:

- Nieuwkomers versus 'Ervaren met continue aanpak'12

- Nieuwkomers versus ‘Geen gesprekken'

- Nieuwkomers versus 'Ervaren met continue aanpak + Ervaren met nieuwe aanpak'

Naast het feit dat er verschillende controle groepen mogelijk zijn, dienen we in de analyses ook rekening mee te houden dat het $\mathrm{MBO}$ met twee leerwegen en vier niveaus een uitermate heterogene groep van gediplomeerden kent met elk afzonderlijke problemen. Zo kennen de gediplomeerden van het MBO-BBL in de regel een veel beter arbeidsmarktperspectief tijdens de transitie tussen onderwijs en arbeidsmark $\mathrm{t}^{13}$ maar tegelijkertijd ook een aanzienlijk lager aandeel gediplomeerden dat doorstroomt naar een vervolgopleiding dan gediplomeerden van MBO-BOL. Maar ook binnen het MBO-BOL zijn er wat het arbeidsmarktintrede betreft aanzienlijke verschillen te zien. Zeker in tijden van een economische crisis is de kans op werk voor de gediplomeerden van opleidingen in het MBO-BOL niveau I en 2 aanzienlijk kleiner dan voor de gediplomeerden van opleidingen in het MBO-BOL niveau 3 en 4 . Gezien er daarmee verschillende effecten te verwachten zijn voor de gediplomeerden van de twee leerwegen (MBO-BOL en MBO-BBL), alsmede verschillende effecten afhankelijk van het niveau van de opleiding, zijn er afzonderlijke analyses uitgevoerd voor:

- $\quad$ MBO Totaal

- $\mathrm{MBO-BOL}$ (en daarin ook apart voor niveau I/2 en niveau 3/4)

- $\quad \mathrm{MBO}$ BBL (en daarin ook apart voor niveau $\mathrm{I} / 2$ en niveau 3/4)

In totaal is er dan ook voor gekozen om 2I afzonderlijke 'difference-in-difference' analyses uit te voeren.

I2. In de voorliggende analyses wordt daarbij de aanname gedaan dat de groep school-domein combinaties die als 'ervaren met continue aanpak' getypeerd zijn, inderdaad geen wijzigingen in de aanpak van exitgesprekken heeft plaatsgevonden. Met andere woorden, het wordt verondersteld dat deze groep de exitgesprekken in het schooljaar 2012/2013 op een identieke wijze vorm had gegeven indien het School Ex 2.0 programma niet van start was gegaan.

I3. Zie bijvoorbeeld, ROA (20I3), Schoolverlaters tussen onderwijs en arbeidsmarkt 2012. 
Tot slot dient er bij 'difference-in-difference' analyses rekening mee gehouden te worden dat de 'treatment groep' en de controle groep zo veel mogelijk identiek dienen te zijn, met uitzondering van het treatment effect. In tabel 3.2 en tabel 3.3 hebben we laten zien dat dit op een aantal aspecten relatief goed het geval is maar dat er ook verschillen zijn. Daarnaast kunnen additionele aspecten van belang zijn. School-domein combinaties verschillen immers niet alleen in hun toewijzing tot een van de vier groepen, of wat betreft de samenstelling van het opleidingsniveau van hun gediplomeerden, maar bijvoorbeeld ook wat betreft de woonregio van hun leerlingen. Aangezien bijvoorbeeld de arbeidsmarktregio waarvoor men opleidt van invloed kan zijn op het belang van doorleren, is de set van analyses twee keer uitgevoerd. In eerste instantie zonder additionele controlevariabelen en een tweede keer waarbij voor in de registerdata van DUO aanwezige achtergrondkenmerken is gecontroleerd:

- Samenstelling qua niveau van gediplomeerden

- Samenstelling qua leerweg

- Dummy's voor domeinen

- Gemiddelde leeftijd

- Aandeel jongens

- Samenstelling qua etniciteit

- Aandeel gediplomeerden dat al eerder een MBO-diploma heeft behaald

- Samenstelling qua arbeidsmarktregio waar de gediplomeerden wonen

Tabel 3.4 presenteert de coëfficiënten voor de 'interactie' dummy afkomstig van de 2I verschillende analyses van de tweede set van 2I analyses (inclusief additionele controlevariabelen) en tussen haakjes de standaard fout van de 'interactie' dummy. ${ }^{14}$, is Aangezien geen enkele van de in totaal 2I apart geschatte coëfficiënten significant van nul verschilt, dienen we op basis van deze uitgebreide set van analyses vast te stellen dat we geen effect van de invoering van het School Ex 2.0 programma kunnen vaststellen op wat we het 'formele circuit' van exitgesprekken noemen.

Tabel 3.4

Dif-in-Dif analyses van groep 'nieuwkomers' versus: coëfficiënten van interactie dummy

\begin{tabular}{|l|r|r|r|}
\hline MBO totaal & Ervaren continue aanpak & Geen gesprekken & Totale groep ervaren \\
\hline MBO-BOL & $0,002(0,018)$ & $0,008(0,030)$ & $-0,004(0,017)$ \\
\hline MBO-BBL & $0,013(0,025)$ & $0,063(0,038)$ & $0,012(0,022)$ \\
\hline MBO BOL 1/2 & $-0,004(0,026)$ & $-0,075(0,066)$ & $-0,020(0,024)$ \\
\hline MBO-BOL 3/4 & $0,018(0,036)$ & $-0,043(0,060)$ & $0,020(0,033)$ \\
\hline MBO-BBL 1/2 & $0,005(0,028)$ & $0,069(0,050)$ & $0,003(0,026)$ \\
\hline MBO-BBL 3/4 & $-0.017(0,-33)$ & $-0,088(0,085)$ & $-0,028(0,030)$ \\
\hline
\end{tabular}

Bron: DU0, eigen bewerking ROA; ${ }^{* * *} /{ }^{* * *}$ significant verschillend van nul op $10 \% / 5 \% / 1 \%$ niveau

I4. De resultaten van de eerste set van 2I analyses (zonder additionele controlevariabelen) verschillen kwalitatief niet van de hier gepresenteerde uitkomsten van de tweede set van 2I analyses.

I5. De volledige resultaten afkomstig van de Dif-in-Dif analyses zijn op aanvraag bij de auteurs beschikbaar. 


\subsection{2 eterogeniteit binnen het 'formele circuit' van exitgesprekken}

In de voorafgaande paragraaf zijn eventuele verschillen tussen school-domein combinaties wat de opzet van het 'formele circuit' betreft genegeerd, met uitzondering van de ervaring die zij daarmee hebben. In deze paragraaf gaan we nader in op de mogelijk onderliggende heterogeniteit op basis van de antwoorden van scholen op vragen die betrekking hebben op onder andere:

- Het aandeel jongeren dat een gesprek heeft gehad

- De medewerkers die exitgesprekken binnen de school hebben gevoerd

- De gemiddelde duur van exitgesprekken

- Het gemiddeld aantal gesprekken dat een leerling had

- De vraag of er ook al voorafgaand aan mei (de start van het School Ex programma) exitgesprekken zijn gevoerd

- De thema's die in de gesprekken aan bod zijn gekomen

Deze informatie is voor alle school-domein combinaties in principe beschikbaar op basis van de enquête onder de scholen. De uitzonderingen zijn inderdaad de school-domein combinaties die aangegeven hebben dat er in het schooljaar 20I2/20I3 geen exitgesprekken hebben plaatsgevonden. In hoofdstuk 2 hebben we al laten zien dat er wat betreft het aandeel jongeren dat volgens de scholen een exitgesprek heeft gehad, wat betreft de medewerkers die daarbij betrokken waren alsmede de timing van de gesprekken nogal duidelijke verschillen te vinden zijn. Tabel 3.5 laat zien dat dit ook bijvoorbeeld geldt voor de gemiddelde duur van exitgesprekken of het gemiddeld aantal gesprekken.

Tabel 3.5

Verschillende manieren van opzet van exitgesprekken

\begin{tabular}{|l|r|r|r|}
\hline & $\begin{array}{r}\text { Ervaren met continue } \\
\text { aanpak }\end{array}$ & $\begin{array}{r}\text { Ervaren met nieuwe } \\
\text { aanpak }\end{array}$ & Nieuwkomer \\
\hline Gemiddeld meer dan 1 gesprek per leerling (\%) & 26 & 10 & 4 \\
\hline \% Gesprekken van meer dan 10 minuten & 82 & 65 & 75 \\
\hline
\end{tabular}

Bron: Enquête onder scholen

Om nader op de mogelijke effecten van deze heterogeniteit in te gaan, is een aantal aanvullende analyses uitgevoerd. ${ }^{16}$

In eerste instantie is een aantal analyses uitgevoerd ${ }^{17}$, waarin getracht wordt het aandeel gediplomeerden per school-domein combinatie van het schooljaar 2012/2013 dat doorstroomd naar een vervolgopleiding op basis van de DUO bestanden nader te verklaren door de bovengenoemde verschillen in aanpak. De resultaten van deze analyses bevestigen

I6. De uitgebreide analyse resultaten zijn op aanvraag bij de auteurs beschikbaar.

17. We dienen de lezer nog een keer erop te attenderen dat de informatie afkomstig van de scholen ons inzicht biedt in het 'formele circuit' en niet per definitie overeen hoeft te komen met de dagelijkse praktijk van gesprekken tussen mentoren/docenten en (aanstaande) gediplomeerden. 
het beeld dat de inrichting van het 'formele circuit' van de exitgesprekken geen invloed heeft op het aandeel jongeren dat doorstroomt naar een vervolgopleiding.

Een tweede set van mogelijke heterogeniteit waar we in onze oorspronkelijk 'Differencein-Difference' analyses niet rekening mee gehouden hebben, is het feit dat binnen de groep 'nieuwkomers' eveneens verschillen zijn wat betreft de invoering van het 'formele circuit' in 20I3. De ene school-domein combinatie heeft wat het 'formele' circuit betreft een snelle start gemaakt en kon daarmee naar eigen inzicht nog flink wat jongeren spreken, de andere was wat later van start gegaan. De vraag is wat de impact hiervan is. Om dit nader te analyseren is voor de groep nieuwkomers wederom een aantal analyses uitgevoerd. Daarbij is dit keer getracht het verschil in het percentage dat doorstroomt (percentage dat in 20I2/20I3 is doorgestroomd minus het percentage dat in 20II/2OI2 is doorgestroomd) te verklaren op basis van verschillen in de aanpak in 20I2/2013 ${ }^{18}$ Ook de resultaten van deze analyses bevestigen het tot nu toe gepresenteerde beeld, dat de inrichting van het 'formele circuit' geen invloed heeft op het aandeel gediplomeerden dat verder gaat leren.

\subsubsection{Plafond effecten}

Eerder lieten we op basis van de doorstroomgegevens van de gediplomeerden al zien dat er tussen de schooljaren 20II/20I2 en 20I2/20I3 geen duidelijke stijging zichtbaar is. Het is de vraag of het $\mathrm{MBO}$ eventueel gedeeltelijk met plafondeffecten te maken heeft. Er zijn twee plafond effecten die interessant zijn om nader te analyseren:

a. Het eerste betreft het feit dat het aandeel gediplomeerden dat doorstroomt naar een vervolgopleiding zich al op een (relatief) hoog niveau bevindt, en daardoor een verdere stijging steeds moeilijker haalbaar wordt.Niet iedere MBO leerling heeft bijvoorbeeld voldoende capaciteiten om een niveau 4 opleiding af te ronden en daarna ook nog door te stromen naar een HBO opleiding.

b. Het tweede mogelijke plafondeffect is rechtstreeks gerelateerd aan het voortduren van de economische crisis. Sinds het begin van 2009 is de arbeidsmarkt voor recent gediplomeerden van het $\mathrm{MBO}$ als moeilijk en deels zelfs als heel moeilijk te classificeren. Gestimuleerd door hoge werkloosheidscijfers maar ook eerdere initiatieven vanuit de overheid (School Ex I.o) heeft aan het begin van de economische crisis een groeiend deel van MBO-ers op moment van het behalen van het diploma de beslissing genomen om door te leren. Hierdoor is voor een groeiend deel onder de jongeren die in een bepaald schooljaar het diploma behaalt dit niet het eerste $\mathrm{MBO}$-diploma in hun onderwijs. Deze toenemende stapeling van diploma's kan een versterkende remmende werking hebben op het eerste plafondeffect.

Om deze twee effecten te analyseren is een analyse uitgevoerd waarin het verschil in het aandeel dat is doorgestroomd tussen de jaren 20I2/20I3 en 20II/2OI2 (aandeel dat in $2012 / 2013$ is doorgestroomd minus het aandeel dat in 2011/2012 is doorgestroomd) gere-

I8. We veronderstellen daarbij dat de groep 'nieuwkomers' in II/I2 inderdaad, zoals ze zelf zeggen, geen exitgesprekken hebben gevoerd. De uitgebreide analyse resultaten zijn op aanvraag bij de auteurs beschikbaar 
lateerd aan de vraag tot welke groep van scholen de school-domein combinatie behoort, het aandeel dat in 20II/2OI2 is doorgestroomd (punt a) en het verschil tussen beide jaren in het percentage dat al eerder een MBO-diploma heeft behaald (punt b). Aan de analyse zijn verder de gebruikelijke variabelen afkomstig van de DUO bestand ter controle toegevoegd. Tabel 3.6 laat de kernresultaten uit deze analyse zien. ${ }^{\text {I9 }}$

Tabel 3.6

OLS analyse met afhankelijke variabele: verschil in aandeel doorstroom tussen 2012/2013 en 2011/2012

\begin{tabular}{|l|r|}
\hline & Model 0 \\
\hline Type school-domein combinatie & 0.014 \\
\hline Ervaren met continue aanpak & 0.017 \\
\hline \begin{tabular}{l} 
Ervaren met nieuwe aanpak \\
\hline Nieuwkomer
\end{tabular} & Ref. \\
\hline Geen Gesprekken groep & 0.010 \\
\hline \begin{tabular}{l} 
Doorstroom in het jaar 11/12 \\
\hline Verschil in aandeel dat al eerder MB0-diploma heeft behaald
\end{tabular} & $-0.240^{* * *}$ \\
\hline $\begin{array}{l}\text { Controle voor veranderingen in samenstelling populatie binnen school-domein combinaties } \\
\text { ****** significant op 10\%/5\%1\% niveau } \\
\text { Bron: Enquête onder scholen en DU0, eigen bewerking ROA }\end{array}$ & $-0.187^{* * *}$ \\
\hline
\end{tabular}

De resultaten met betrekking tot de vier groepen van school-domein combinaties bevestigen nog een keer het resultaat dat er tussen deze vier groepen geen significante verschillen zijn wat het doorstroompercentage betreft. Daarnaast lijken er inderdaad plafondeffecten op te treden.

We vinden namelijk een significant negatieve relatie tussen het aandeel dat in 20II/20I2 is doorgestroomd en de toename in het aandeel dat doorstroomt tussen de jaren 20II/20I2 en 2012/2013. Met andere woorden: school-domein combinaties die al een (relatief) hoog aandeel kennen van gediplomeerden die doorstromen naar een vervolgopleiding, kennen een moeilijkere startpositie wat het verder verhogen van dit aandeel betreft dan schooldomein combinaties met een (relatief) laag aandeel doorstroom in 2011/20I2

Ook vinden we dat een toename in het percentage jongeren dat voorafgaand aan het diploma in 2012/2013 al eerder een MBO-diploma heeft behaald op het niveau van schooldomein combinatie negatief gecorreleerd is met het verschil in het percentage tussen de twee schooljaren dat doorstroomt naar een vervolgopleiding.

\subsubsection{Conclusies 'Evaluatie van het formele circuit van exitgesprekken'}

De analyses gepresenteerd in dit hoofdstuk bieden een aantal interessante conclusies:

I9. De volledige resultaten, zijn op aanvraag bij de auteurs beschikbaar. 
- Scholen hebben op grote schaal exitgesprekken gevoerd in het schooljaar 20I2/2013. Dit wordt zowel door de uitkomsten van de enquête onder scholen als de enquête onder de gediplomeerden bevestigd.

- De nadruk op exitgesprekken binnen het School Ex 2.0 programma lijkt ertoe te hebben geleid dat in scholen waar dit nog niet de gangbare norm was, een 'formeel circuit' van exitgesprekken is opgestart. Er kan echter niet worden aangetoond dat dit tot een hoger aandeel dat doorstroomt naar een vervolgopleiding heft geleid aangezien:

» Het aannemelijk is dat binnen $\mathrm{MBO}$ scholen al langer een 'informeel circuit' van exitgesprekken beschikbaar is. Dat wil zeggen dat docenten, mentoren of bijvoorbeeld studieloopbaanbegeleiders al langer gesprekken met (aanstaande) gediplomeerden voeren over hun (nabije) toekomstplannen en wat ze het best kunnen doen met de capaciteiten die ze hebben opgedaan in de afgeronde opleiding.

» Het informele circuit ook bij de groep scholen dan wel domeinen binnen scholen aanwezig is die in 2014 met een 'formele circuit' zijn gestart.

Ondanks dat de analyses in dit rapport geen effect van het School Ex 2.0 programma onder exitgesprekken laten zien, kan op basis van deze eerste set van analyses niet geconcludeerd worden dat het voeren van exitgesprekken geen positieve effecten kent. Een mogelijke verklaring voor het uitblijven van een positief effect kan gezien worden in het feit dat exitgesprekken niet een nieuwe aanpak binnen het $\mathrm{MBO}$ zijn maar waarschijnlijk al in het schooljaar 20II/20I2 tot gemeengoed behoorde (zie hiervoor Hoofdstuk 2).

\subsection{De waarde van Exitgesprekken: Het informele circuit}

Wie heeft een exitgesprek gehad en wie niet? Worden jongeren door exitgesprekken beïnvloed en zo ja, op welke manier? Deze en andere vragen staan in dit tweede gedeelte van hoofdstuk 3 centraal. De achterliggende doelstellingen zijn daarbij om a) de waarde van exitgesprekken nader te analyseren en b) vast te stellen of de inzet van exitgesprekken in toekomst doelmatiger kan plaatsvinden. Om deze doelstellingen te bereiken staan we navolgend stil bij de uitkomsten van de enquête onder de recent gediplomeerden van het $\mathrm{MBO} .{ }^{20}$ We gaan achtereenvolgend in op de volgende vragen:

- Wie heeft er een gesprek gehad en wie niet?

- Is er een verband tussen het gesprek en de kans dat een recent gediplomeerde MBO-er op moment van enquête een opleiding volgt?

- Zijn jongeren door de gesprekken beïnvloed en zo ja, op welke manier?

- Hoe beoordelen de recent gediplomeerden de gesprekken?

20. Voor een verantwoording van deze enquête, zie Hoofdstuk 2. 


\subsubsection{Wie heeft er een gesprek gehad?}

Eerder in dit rapport is al op basis van de uitkomsten van de enquête onder de scholen vastgesteld dat er in het voorjaar van 2013 breed door bijna het hele $\mathrm{MBO}$ exitgesprekken gevoerd zijn. Immers, de groep school-domein combinaties die aangegeven hebben dat er wat het formele circuit betreft geen exitgesprekken hebben plaatsgevonden, omvatte slechts zo'n $4 \%$ van de gediplomeerden van het schooljaar 20I2/20I3 van de scholen die aan de enquête hebben deelgenomen. Dat deze bevinding ook voor het 'informele' circuit van exitgesprekken geldt, wordt zichtbaar in Figuur 3.4 en Tabel 3.7. Figuur 3.4 laat voor een vijftigtal scholen, welke afzonderlijk door minimaal 20 respondenten vertegenwoordigd zijn in het databestand, het aandeel respondenten zien dat volgens eigen zeggen een of zelfs meerdere exitgesprek(ken) heeft gehad. Het aandeel varieert daarbij tussen de $53 \%$ en bijna 90\% waarbij voor het gros van de scholen geldt dat het aandeel rond de $70 \%$ is. Onder de totale groep respondenten is het aandeel dan ook net boven de $70 \%$.

\section{Figuur 3.4}

Percentage MBO-gediplomeerden dat aangeeft een exitgesprek te hebben gehad, per ROC/AOC (minimaal 20 respondenten)

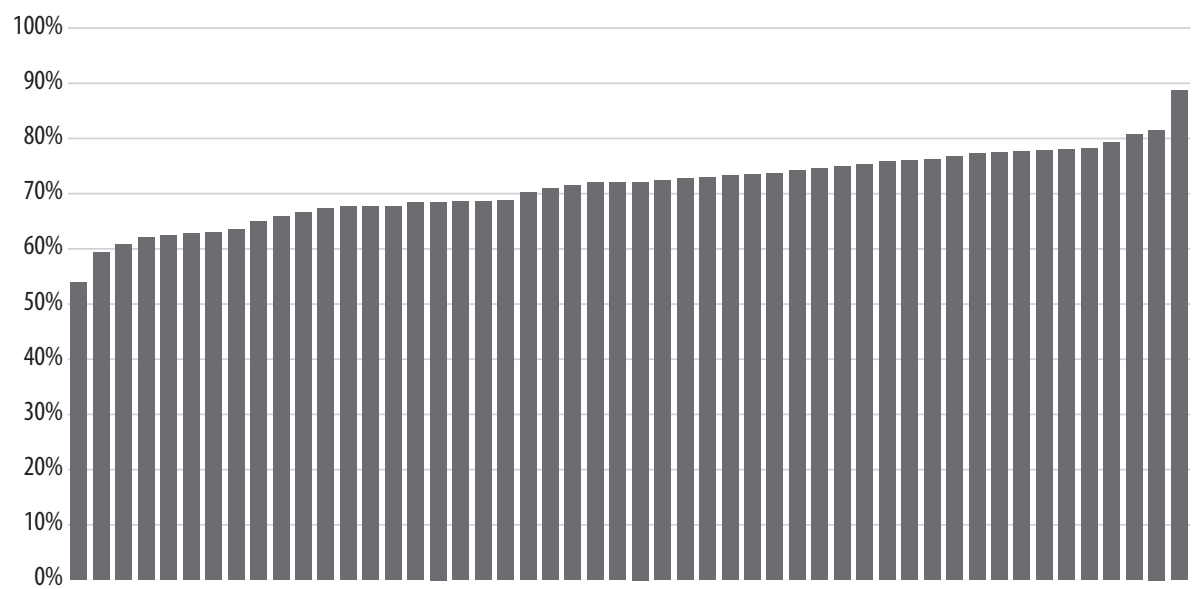

Bron: Enquête onder MB0-gediplomeerden

Naast het feit dat er relatief weinig verschil tussen scholen zichtbaar is, laat Tabel 3.7 zien dat er ook tussen de vier opleidingsniveaus, de opleidingssectoren ${ }^{21}$ en de twee leerwegen verrassend weinig verschil in het aandeel gediplomeerden dat aangeeft een exitgesprek te hebben gehad te vinden is. Onder de MBO-BOL gediplomeerden ligt het aandeel respondenten dat meldt een exitgesprek te hebben gehad bij $73 \%$ (variërend tussen de $70 \%$ op niveau 3 en $77 \%$ op niveau I) en onder de MBO-BBL gediplomeerden is dat $65 \%$ (variërend tussen de $62 \%$ op niveau 2 en $69 \%$ op niveau 3). Gezien het feit dat MBO-BBL leerlingen de meeste tijd op het werk doorbrengen, is zeker dit percentage als hoog te clas-

2I. Nadere analyses laten zien binnen een bepaalde opleidingssector geen grote verschillen te vinden zijn tussen de opleidingsdomeinen. 
sificeren. Ook wat de afzonderlijke sectoren betreft is er relatief weinig verschil binnen een leerweg te zien. Uitzondering is daarbij de MBO-BBL niveau I sector Landbouw die relatief laat scoort.

\section{Tabel 3.7}

Percentage respondenten dat een exitgesprek heeft gehad

\begin{tabular}{|r|r|r|r|r|r|r|}
\hline & Niveau 1 & Niveau 2 & Niveau 3 & Niveau 4 & Totaal \\
\hline MBO-BOL & 77 & 75 & 70 & 73 & 73 \\
\hline MB0-BBL & 64 & 62 & 69 & 64 & \\
\hline & Landbouw & Techniek & Economie & Gezondheidszorg & $\begin{array}{r}\text { Gedrag en } \\
\text { Maatschappij }\end{array}$ & Totaal \\
\hline MBO-BOL & 73 & 71 & 71 & 75 & 77 & 73 \\
\hline MBO-BBL & 56 & 61 & 64 & 74 & 70 & 65 \\
\hline
\end{tabular}

Bron: Enquête onder MBO-gediplomeerden

Bovenstaande uitkomsten laten zien dat, hoewel minimaal, er wel lichte verschillen zichtbaar zijn tussen scholen, tussen de twee leerwegen en daarbinnen tussen de opleidingsniveaus alsmede tussen de opleidingssectoren. De vraag is echter of deze verschillen blijven bestaan als er voor verdergaande kenmerken van de gediplomeerden gecontroleerd wordt en in hoeverre precies deze kenmerken van belang zijn bij de vraag 'welke jongeren hebben een exitgesprek gehad?'. Om dit nader te analyseren is via een multivariate analyse de kans geschat dat een gediplomeerde schoolverlater meldt dat hij of zij de toekomstplannen in een of meerdere gesprekken met iemand van de school besproken heeft (zie bijlage 2 voor de volledige resultaten).

De uitkomsten hiervan bevestigen in eerste instantie het boven gepresenteerde beeld: het aandeel jongeren dat een gesprek heeft gehad, verschilt niet significant tussen de twee leerwegen, en binnen de leerwegen verschilt het niet significant tussen de vier niveaus. Onder de gediplomeerden van de sectoren Economie en Techniek melden respondenten significant minder vaak dat ze een exitgesprek hebben gehad (-6,5\%-punt) dan onder de gediplomeerden van de sectoren Zorg \& Welzijn en Gedrag \& Maatschappij. Zoals we in tabel 3.7 echter al zagen, geldt ook voor deze groep jongeren dat minimaal 6I\% (MBOBBL Techniek) meldt een exitgesprek op school gehad te hebben.

Gegeven de leerweg, opleidingssector en het opleidingsniveau laat de analyses nog een aantal verdere interessante resultaten zien:

- Met toenemende leeftijd van de leerling neemt de kans op een gesprek af. ${ }^{22}$ Dit is in lijn met het resultaat dat een relatief klein aantal school-domein combinaties aangegeven heeft dat leerlingen boven de 27 jaar niet in aanmerking kwamen voor

22. De lezer dient hierbij rekening te houden dat alle respondenten op moment van enquête maximaal 30 jaar oud zijn en dit geen effect is van de relatief grote groep 30-plussers in het $\mathrm{MBO}$ en in meer detail in het MBO-BBL. 
een exitgesprek. Nadere analyses laten echter zien dat er geen echte 'breuk' zichtbaar is in de kans op gesprek tussen de groep 26 jarigen en de groep 27 jarigen.

- Jongeren die achteraf bezien wederom voor dezelfde opleiding aan dezelfde school zouden kiezen, hebben een hogere kans (+ 8\%-punt) dat ze een of meerdere gesprekken hebben gehad. Belangrijk is daarbij dat het niet zeker is welke richting deze relatie kent:

» Jongeren die tevreden zijn met de opleiding hebben eerder een gesprek gehad (eventueel ook op eigen initiatief);

» Jongeren die geen gesprek hebben gehad zijn ontevreden met de gevolgde opleiding omdat ze onder andere geen exitgesprek hebben gehad.

- Jongeren die hun diploma in de periode april - september 2013 hebben behaald kennen een hogere kans op een exitgesprek (+5\%-punt) dan degenen die in de periode ervoor of juist erna een exitgesprek gehad hebben. Dit kan een indicatie zijn dat de aandacht besteed aan het School Ex 2.0 programma inderdaad tot een versterkte impuls door de scholen heeft geleidt.

We kunnen dan ook als eerste conclusie trekken dat scholen niet selectief omgegaan zijn met het inzetten van exitgesprekken. Of dit, gegeven eventuele budget beperkingen als doelmatig gezien kan worden, komt in de latere delen van dit hoofdstuk aan bod.

\subsubsection{Wie gaat doorleren?}

De expliciete doelstelling van het School Ex 2.0 programma, en zeker van het onderdeel Exitgesprekken, is om jongeren te stimuleren om hun onderwijscarrière voort te zetten. Onze eerstvolgende vraag dient dan ook te zijn 'wie gaat er doorleren en wie niet?' en daaraan gerelateerd, 'wat is de invloed van exitgesprekken op deze keuze?'. Om te beginnen laat Tabel 3.8 zien dat van de respondenten afkomstig van het MBO-BOL meer dan de helft $(58 \%)$ na afstuderen met een vervolgopleiding bezig is terwijl dit onder de respondenten afkomstig van het $\mathrm{MBO}-\mathrm{BBL}$ net geen $30 \%$ is.

Tabel 3.8

Percentage respondenten dat op moment van enquête aan een vervolgopleiding bezig is

\begin{tabular}{|l|r|r|r|r|r|r|}
\hline & Niveau 1 & Niveau 2 & Niveau 3 & Niveau 4 & Totaal \\
\hline MBO-BOL & 76 & 66 & 53 & 55 & 58 \\
\hline MBO-BBL & 31 & 44 & 30 & 15 & 29 \\
\hline
\end{tabular}

Bron: Enquête onder MB0-gediplomeerden

Bijna 30\% van de respondenten (MBO-BBL: 29\% en MBO-BOL:27\%) meldt dat de belangrijkste reden om door te leren was dat 'verder leren leuk is'. Voor $23 \%$ van de gediplomeerden van het MBO-BBL en 31\% van de gediplomeerden van het MBO-BOL is het echter eerder een noodzaak om door te leren. Deze jongeren zijn namelijk van mening dat de afgeronde opleiding te weinig kansen op het vinden van een baan biedt. De slechte arbeidsmarktkansen van de afgeronde opleiding is daarbij bovengemiddeld vaak een reden voor het verder leren bij de gediplomeerden van de sector Gedrag \& 
Maatschappij. Van deze groep geeft namelijk 44\% (MBO-BOL: 44\%; MBO-BBL 46\%) aan dat de slechte kansen op het vinden van een baan de belangrijkste reden was om verder te gaan leren. Nog eens tussen de $5 \%$ (MBO-BBL) en $13 \%$ (MBO-BOL) meldt dat zij geen baan in de richting van de afgeronde opleiding wensten en daarom het doorleren met een verandering in de opleidingsrichting combineerden.

Kijken we naar de redenen waarom jongeren ervoor gekozen hebben om zich op de arbeidsmarkt aan te bieden en niet door te leren, dan staat 'werken is leuker dan doorleren' met zo'n $20 \%$ aan top van de redenen bij zowel de gediplomeerden van het MBO-BOL als de gediplomeerden van het MBO-BBL. Daarnaast meldt net iets meer dan IO\% dat ze een baan aangeboden kregen en nog eens zo'n I2\% dat ze een inkomen nodig hadden. Voor iets minder dan IO\% (MBO-BOL: $9 \%$ en MBO-BBL: $8 \%$ ) is naar eigen inzicht het afgeronde opleidingsniveau het maximaal haalbare. Tot slot meldt $5 \%$ (MBO-BOL), respectievelijk 6\% (MBO-BBL) dat ze graag verder waren gaan leren maar geen BPV-/ Stageplek konden vinden en daardoor gedwongen werden om te stoppen met hun onderwijscarrière.

Om de vraag 'wie is gaan doorleren?' te analyseren, is een aantal multivariate analyses uitgevoerd (zie bijlage 3 voor de volledige resultaten). In eerste instantie gaan we daarbij in op de algemene vraag 'wie is gaan doorleren?' en in tweede instantie op de vraag 'welke invloed heeft een exitgesprek op de kans dat men is gaan doorleren?'.

Voordat we in paragraaf 3.2.3 nader ingaan op de vraag wat de invloed van het exitgesprek is, staan we stil bij een aantal andere relevante resultaten van de multivariate analyses op de algemene vraag 'wie is gaan doorleren?'.:

\section{Invloed van leerweg, niveau en sector}

De gediplomeerden van het $M B O-B O L$ stromen vaker door naar een vervolgopleiding dan de gediplomeerden van het $M B O-B B L$. Dit bevestigt de uitkomsten gepresenteerd in Tabel 3.8 en is eerder in dit rapport ook al aan de orde gekomen op basis van registerdata afkomstig van DUO (zie Figuur 2.I in hoofdstuk 2).

Met toenemend onderwijsniveau neemt de kans af dat men verder gaat leren. Dat dit niet alleen een significante maar ook uitermate relevante uitkomst is, wordt eveneens bevestigd door de resultaten gepresenteerd in Tabel 3.8. Zo stroomt 'slechts' $15 \%$ van de gediplomeerden van het $\mathrm{MBO}-\mathrm{BBL}$ niveau 4 door naar een vervolgopleiding terwijl dit onder de gediplomeerden van het MBO-BBL niveau $244 \%$ is. Ook onder de gediplomeerden van het MBO-BOL zien we relatief sterke verschillen wat dit betreft (zie Tabel 3.8).

Gediplomeerden van de sector Zorg en Welzijn en Landbouw stromen relatief minder vaak door. Terwijl het percentage respondenten van de sector Zorg \& Welzijn dat doorstroom respectievelijk $15 \%(\mathrm{MBO}-\mathrm{BBL})$ en $5 \mathrm{I} \%(\mathrm{MBO}-\mathrm{BOL})$ is en de cijfers voor de sector Landbouw 2I\%, respectievelijk $45 \%$ zijn, liggen de percentages bij de andere drie 
sectoren in het MBO-BBL tussen de 23\% (Gedrag \& Maatschappij) en 40\% (Techniek) en in het MBO-BOL tussen de $56 \%$ (Techniek) en 64\% (Economie).

\section{Invloed van persoonlijke achtergrondkenmerken}

Jongeren van niet-westerse afkomst stromen vaker door naar een vervolgopleiding dan autochtone jongeren ( $+I 7 \%$-punt). Dit resultaat is niet direct een uitkomst van de recente economische crisis en daardoor ook niet een gevolg van de relatief sterk verminderde arbeidsmarktkansen van jongeren van niet-westerse afkomst (zie bijvoorbeeld SCP, 20I4) ${ }^{23}$. Gezien het feit dat de analyses expliciet voor het onderwijsniveau, de leerweg en de opleidingssector controleren is dit resultaat ook niet te verklaren door een oververtegenwoordiging van deze groep jongeren in het $\mathrm{MBO}-\mathrm{BOL}$ dan wel de lagere opleidingsniveaus.

Opleidingsniveau ouders speelt geen rol. Het is interessant om vast te stellen dat het opleidingsniveau van de ouders, gegeven de controle voor de andere achtergrondkenmerken en de afgeronde opleiding, geen invloed heeft op de kans dat men verder gaat leren. Hierbij dienen we echter de kanttekening te plaatsen dat de invloed van het opleidingsniveau van de ouders indirect via de eerdere studiekeuze kan verlopen. Dat wil zeggen, dat ouders van jongeren die een diploma in het MBO-BOL behaald hebben in de regel een hoger opleidingsniveau kennen (zo heeft $28 \%$ van de respondenten afkomstig van het $\mathrm{MBO}-\mathrm{BOL}$ een vader met een hoger onderwijs diploma en is dit onder de jongeren onder de respondenten afkomstig van het MBO-BBL 23\%). Verder laten de data zien dat binnen een leerweg het aandeel respondenten met een hoog opgeleide vader toeneemt met toenemend opleidingsniveau waarvan men het diploma heeft behaald.

Geen invloed van problemen met drugs, financiën etc. Op basis van de zelf gerapporteerde problemen die jongeren kennen (financiële problemen, contacten met justitie, drugsgebruik, veelvoudig gebruik van internet/computerspelen/gokspelen, problemen met woonsituatie of problemen met familie/ouders/verzorgers) kan niet vastgesteld worden dat deze een verder verloop van de onderwijs carrière in de weg staan.

Tot slot zien we dat jongeren die verder zijn gaan leren zich zelf eerder typeren als jongeren die wensen door te leren tot het maximaal haalbare diploma en minder sterk als jongeren die zo snel mogelijk wensen de arbeidsmarkt op te gaan. Jongeren die een voorkeur hebben voor een baan die goed aansluit bij de gevolgde opleiding zijn vaker terug te vinden in een vervolgopleiding dan jongeren die een voorkeur hebben om na behalen van het diploma zo snel mogelijk een baan te vinden.

Voor de hier voorliggende evaluatie is het natuurlijk vooral van belang om te zien in hoeverre exitgesprekken een toegevoegde waarde kennen. Hiervoor is in de analyse opgenomen of jongeren a) een gesprek hebben gehad, b) de school via een formulier/enquête geïnformeerd hebben over de toekomstplannen of c) geen informatie over de toekomst-

23. SCP (20I4), Jaarrapport Integratie, Den Haag. 
plannen aan de school hebben doorgeven. De resultaten van deze analyse laten zien dater geen verschil is in het doorstroomgedrag tussen jongeren die geen informatie hebben doorgegeven en jongeren die dat wel gedaan hebben (onafhankelijk van de manier waarop de informatie verstrekt is). Ook zien we dat jongeren die een gesprek hebben gehad eerder op moment van enquête met een vervolgopleiding bezig zijn dan jongeren die slechts een formulier/enquête ingevuld hebben.

\subsubsection{Wie is beïnvloed?}

Om erachter te komen of jongeren door de gesprekken met bijvoorbeeld docenten, mentoren of SLB-ers beïnvloed zijn, is aan de respondenten die minimaal een gesprek hebben gehad gevraagd aan te geven of, en zo ja in welke mate en op welke manier, zij beïnvloed zijn. Tabel 3.9 presenteert de antwoorden op de vraag (manier van beïnvloeding) per onderwijsniveau binnen een bepaalde leerweg. Onder alle respondenten die een gesprek hebben gehad, geeft $27 \%$ te kennen op een of de ander manier via de gesprekken beïnvloed te zijn. Onder de respondenten van het MBO-BOL niveau I is het zelfs bijna $40 \%$. Hiermee wordt duidelijk dat exitgesprekken een duidelijke invloed hebben op de leerlingen. Dat de doelstelling van de exitgesprekken niet per definitie vooraf duidelijk is, wordt zichtbaar als we naar de uitkomst van de invloed kijken. Op MBO niveau zien we dat $4 \%$ van de respondenten aangeeft alsnog verder te zijn gaan leren hoewel dat niet hun eerste keuze was, en nog eens $4,5 \%$ een andere studie heeft gekozen dan zij eerst van plan waren. Daarnaast heeft zo'n $6 \%$ ervoor gekozen om alsnog op zoek te gaan naar een baan. I $2 \%$ is tot slot op een andere manier beïnvloed. Een analyse van deze anders categorie laat een heel divers beeld zien zonder dat de mogelijkheid bestaat om deze groep duidelijk tot een van de eerste groep toe te wijzen.

\section{Tabel 3.9}

Beïnvloeding door gesprek?

\begin{tabular}{|c|c|c|c|c|c|c|c|c|c|}
\hline & BOL 1 & BOL 2 & BOL 3 & BOL 4 & BBL 1 & BBL 2 & BBL 3 & BBL4 & Totaal \\
\hline $\begin{array}{l}\text { Niet, wat ik nu doe was ik toch al } \\
\text { van plan }\end{array}$ & $61.2 \%$ & $66.1 \%$ & $70.9 \%$ & $77.4 \%$ & $58.3 \%$ & $68.0 \%$ & $74.0 \%$ & $77.0 \%$ & $72.9 \%$ \\
\hline $\begin{array}{l}\text { Ik ben gaan doorleren, hoewel dat in } \\
\text { eerste instantie niet mijn plan was }\end{array}$ & $12.2 \%$ & $5.2 \%$ & $5.6 \%$ & $3.0 \%$ & $2.8 \%$ & $6.7 \%$ & $3.3 \%$ & $.5 \%$ & $4.1 \%$ \\
\hline $\begin{array}{l}\text { Ik ben een andere opleiding gaan } \\
\text { volgen dan ik in eerste instantie van } \\
\text { plan was }\end{array}$ & $10.2 \%$ & $6.7 \%$ & $4.0 \%$ & $4.5 \%$ & $5.6 \%$ & $3.1 \%$ & $2.9 \%$ & $1.5 \%$ & $4.5 \%$ \\
\hline $\begin{array}{l}\text { Ik ben werk gaan zoeken, hoewel dat } \\
\text { in eerste instantie niet mijn plan was }\end{array}$ & $3.1 \%$ & $8.8 \%$ & $6.8 \%$ & $6.2 \%$ & $8.3 \%$ & $4.1 \%$ & $5.0 \%$ & $3.4 \%$ & $6.1 \%$ \\
\hline Anders, namelijk: & $13.3 \%$ & $13.2 \%$ & $12.8 \%$ & $9.0 \%$ & $25.0 \%$ & $18.0 \%$ & $14.9 \%$ & $17.6 \%$ & $12.4 \%$ \\
\hline
\end{tabular}

Bron: Enquête onder MBO-gediplomeerden

Wat het aandeel betreft dat 'alsnog verder is gaan leren', laat Tabel 3.9 zien dat dit in de regel hoger ligt bij de gediplomeerden van het $\mathrm{MBO}-\mathrm{BOL}$ en binnen deze groep met I2\% duidelijk bovengemiddeld vaak gemeld wordt bij de gediplomeerden van het MBO-BOL niveau I. Deze groep kent daarnaast ook met IO\% een bovengemiddeld aandeel jongeren 
dat naar aanleiding van de gesprekken voor een andere opleiding heeft gekozen dan ze in eerste instantie van plan waren. De invloed van de exitgesprekken lijkt daarmee het sterkst te zijn bij de (aanstaande) gediplomeerden die het meest kwetsbaar zijn indien zij zich op de arbeidsmarkt aanbieden.

De centrale vraag in de voorliggende context is natuurlijk of de invloed verschilt afhankelijk van de onderwerpen die tijdens de gesprekken aan bod zijn gekomen en in hoeverre de invloed afhankelijk is van de persoon met wie er gesprokken is. Om dit nader te analyseren is een aantal multivariate analyse uitgevoerd (zie bijlages 4.I en 4.2).

In eerste instantie is geanalyseerd of er bepaalde aspecten zijn die in het algemeen ertoe leiden dat jongeren in hun keuze beïnvloed worden zonder de manier van beïnvloeding nader te onderscheiden. Hiervoor zijn een tweetal analyses uitgevoerd:

- De eerste (zie bijlage 4.2) kent als afhankelijke variabele de vraag 'In welke mate bent u door dit gesprek/deze gesprekken beïnvloed bij het maken van een keuze wat $\mathrm{u}$ na het behalen van het diploma ging doen?' (gemeten op een 5-punt Likert schaal waarbij voor de analyses de antwoord categorieën 4 en 5 samengevat zijn als 'sterk beïnvloed').

- $\quad$ De tweede (zie bijlage 4.I) kent als afhankelijke variabele de vraag "Hoe heeft dit gesprek / hebben deze gesprekken uw uiteindelijke keuze beïnvloed? Zie hiervoor ook Tabel 3.8)

De eerste vraag kan als een bredere mate van beïnvloeding gezien worden dan de tweede, die meer toegespitst is op de uiteindelijke keuze.

Op basis van het tweetal analyses kan geconcludeerd worden dat exitgesprekken in het algemeen meer van invloed zijn op $^{24}$ :

- Jongeren afkomstig van opleidingen op niveau I en 2

- Jongeren van niet-westerse afkomst

Jongeren afkomstig van niveau i hebben na controle voor onder andere achtergrondkenmerken een $15 \%$-punt hogere kans om in de uiteindelijke keuze beïnvloed te zijn en een $25 \%$-punt hogere kans om in het algemeen 'sterk beïnvloed' te zijn. Voor de jongeren afkomstig van niveau 2 zijn de cijfers I2\%-punt respectievelijk 2I\%-punt. Voor jongeren van niet-westerse afkomst is de kans dat zij 'sterk beïnvloed' zijn door het gesprek zo'n I4\%-punt hoger terwijl de kans dat zij van keuze zijn veranderd niet significant afwijkt van de kans onder de groep autochtone jongeren. Deze twee uitkomsten zijn uitermate cruciaal, aangezien het hierbij precies om de twee groepen van jongeren gaat die structureel, maar nog versterkt tijdens de meest recente economische crisis, als uiterst kwetsbaar op de arbeidsmarkt geclassificeerd dienen te worden. Het is dan ook interessant om deze twee resultaten direct te koppelen aan onze eerdere bevindingen, namelijk dat de scholen wat het voeren van exitgesprekken betreft niet per se selectief omgegaan zijn en dat er

24. De invloed is daarbij of via de eerste vraag of via de tweede vraag vastgesteld dan wel via beide vragen. 
daardoor geen significant verschil is tussen het aandeel jongeren van een bepaald onderwijsniveau of van een bepaald etnische achtergrond dat een exitgesprek heeft gehad. ${ }^{25}$ Gezien de verschillen in mate van beïnvloeding leidt dit tot de volgende aanbeveling:

Indien door budget beperkingen (tijd, geld) keuzes gemaakt dienen te worden aan wie een exitgesprek aangeboden wordt, is het aan te raden om jongeren afkomstig van de onderwijsniveaus I en 2 dan wel jongeren van niet-westerse afkomst prioriteit te geven.

Daarnaast laten de twee analyses zien dat de gemiddelde duur van het gesprek en het aantal gesprekken positief gecorreleerd zijn met de vraag of men beïnvloed is. Tot slot laten de twee analyses zien dat dit ook geldt voor de inhoud van het exitgesprek. ${ }^{26}$ Dit wordt nog duidelijker als we in de afzonderlijke modellen de verschillende manieren van beïnvloeding analyseren. Hiervoor zijn de drie hoofdmanieren van invloed ('alsnog verder gaan leren', 'andere opleiding gekozen' en 'alsnog op zoek naar een baan') afgezet tegen 'geen invloed'. ${ }^{27}$ Daarin is te zien dat indien tijdens het gesprek de lange termijn plannen aan bod zijn gekomen, dit in de regel negatief gecorreleerd is met de kans dat de gediplomeerden aangeven dat ze door het gesprek beïnvloed zijn. Het tegenovergestelde zien we indien tijdens het gesprek mogelijke vervolgopleiding aan bod zijn gekomen. Het laatste is daarbij vooral gecorreleerd met een eventuele heroverweging van de keuze voor een bepaalde opleiding. Hierbij speelt ook de vraag mee of tijdens de gesprekken de capaciteiten van de jongeren aan bod zijn gekomen. Met andere woorden, indien jongeren tot een eventuele verandering in de studiekeuze gekomen zijn, zijn zowel de mogelijke alternatieven alsook de vraag welke vervolgopleidingen bij de capaciteiten van de jongeren passen tijdens het gesprek aan bod gekomen. Wat de vraag betreft of de invloed tot een keuze om alsnog door te gaan leren heeft geleid, is het interessant om vast te stellen dat hiervoor vooral de vraag wat de korte termijn arbeidsmarktperspectieven zijn van belang is. Dit is een indicatie dat jongeren in tijden van een economische crisis inderdaad afgeschrikt kunnen worden voor het betreden van de arbeidsmarkt. ${ }^{28}$

Tabel 3.Io presenteert een aantal verdere kernresultaten op basis van deze vier analyses. ${ }^{29}$ Hierbij komt naar voren dat jongeren afkomstig van niveau I een 8\%-punt hogere kans hebben om alsnog te zijn gaan doorleren dan jongeren afkomstig van niveau 4. Voor de jongeren afkomstig van niveau 2 en niveau 3 is dit nog maar $3 \%$-punt, respectievelijk 2\%-punt. Deze effecten zijn weliswaar significant verschillend van nul, echter slechts

25. In Bijlage 2 is zichtbaar dat het effect van 'niet-westerse afkomst' negatief maar niet significant is.

26. Zowel bij de opzet van het gesprek (duur, antal gesprekken) als bij de inhoud van het gesprek dienen we daarbij rekening te houden dat deze niet per definitie exogeen dienen te zijn. Zo kan het bespreken van mogelijke vervolgopleidingen bij jongeren die tijdens het gesprek aangeven te twijfelen aan hun eerste studiekeuze aan bod komen terwijl dit bij jongeren die aangeven niet te twijfelen niet aan bod kan komen. Aanvullende analyses laten echter zien dat de mogelijke endogeniteit van deze variabelen geen invloed heeft op andere achtergrondkenmerken zoals opleidingsniveau, leerweg of sector.

27. Zie voor de volledige uitkomsten Bijlage 4. De uitkomsten van deze modellen verschillen kwalitatief niet van de uitkomsten van een multinomiale logit analyse.

28. In aanvullende analyses is vastgesteld dat de mogelijke endogeniteit van deze variabelen geen invloed heeft op de uitkomsten wat de andere variabelen betreft.

29. Voor de volledige resultaten, zie Bijlage 4 
op een IO\% significantieniveau. De gediplomeerden van het MBO-BOL kennen een 3\%-punt hogere kans om alsnog op zoek te zijn gegaan naar een baan terwijl we dit keer geen verschillen vinden tussen de jongeren afkomstig van de drie onderscheiden etnische groepen.

Tabel 3.10

Hoe beïnvloed? Kernresultaten van een viertal multivariate analyses

\begin{tabular}{|l|r|r|r|}
\hline & $\begin{array}{r}\text { Alsnog gaan doorleren } \\
\text { versus niet beïnvloed }\end{array}$ & $\begin{array}{r}\text { Wissel van studiekeuze } \\
\text { versus niet beïnvloed }\end{array}$ & $\begin{array}{r}\text { Alsnog op zoek gegaan naar } \\
\text { een baan versus niet beïnvloed }\end{array}$ \\
\hline Onderwijsniveau & $8 \%$-punt* & 0 & 0 \\
\hline Niveau 1 & $3 \%$-punt* & 0 & $4 \%$-punt** \\
\hline Niveau 2 & $2 \%$-punt* & 0 & 0 \\
\hline Niveau 3 & Ref. & Ref. & Ref. \\
\hline Niveau 4 & Ref & 0 & \\
\hline
\end{tabular}

Bron: Enquête onder MB0-gediplomeerden; ${ }^{* *},{ }^{* * *}$ significant op 10\%/5\%/1\% niveau, o resultaat is niet significant van nul verschillend

\subsubsection{Exitgesprekken: tevredenheid en korte termijn uitkomsten}

Het belang van exitgesprekken kan naast de boven gepresenteerde wijze nog op een aantal andere manieren nader in kaart gebracht worden. Hierbij betreft het meer kwalitatieve dan kwantitatieve aspecten, zoals:

- de tevredenheid met de exitgesprekken;

- de vraag of degenen die geen exitgesprekken hadden eveneens graag een dergelijk gesprek op school gevoerd hadden

- de vraag wat het effect van een exitgesprek is op de transitie tussen gevolgde opleiding en vervolgopleiding dan wel gevolgde opleiding en arbeidsmarkt..$^{30}$

Tabel 3.II laat zien hoe nuttig de gediplomeerden de exitgesprekken hebben gevonden. We onderscheiden daarbij een tweetal groepen van gediplomeerden, namelijk degenen die aangeven dat ze door het gesprek in hun keuze op een of de andere manier zijn beïnvloed en degenen die dat niet zijn. In lijn met de algemene verwachting zijn de gesprekken door relatief meer 'beïnvloede' gediplomeerden als (heel) nuttig ervaren dan door 'niet beïnvloede' gediplomeerden. In de eerste groep is het $59 \%$ die de gesprekken als (heel) nuttig ervaren heeft, in de tweede groep is het weliswaar 'slechts' $46 \%$ maar daarmee nog steeds bijna een op de twee. Misschien nog meer van interesse is echter de groep die de gesprekken als niet nuttig heeft ervaren. In beide groepen is dit maximaal $20 \%$ en daarmee een duidelijke minderheid. Hierbij doen zich geen grote verschillen voor tussen de groep die beïnvloed is en de groep die dat niet is. Overigens blijkt uit de enquête onder scholen dat een overgrote meerderheid van $8 \mathrm{r} \%$ van de school-domein combinaties de exitgesprekken nuttig heeft gevonden.

30. Wat deze transitie betreft dienen we echter op te merken dat de enquête slechts een klein aantal maanden na het behalen van het diploma heeft plaatsgevonden en de resultaten met voorzichtigheid geïnterpreteerd dienen te worden. 
Tabel 3.11

Hoe nuttig zijn de gesprekken? (\%)

\begin{tabular}{|l|r|r|r|r|r|} 
& $\begin{array}{r}\text { Helemaal niet } \\
\text { nuttig }\end{array}$ & Niet nuttig & Neutraal & nuttig & Heel nuttig \\
\hline Niet beïnvloed & 6 & 14 & 34 & 34 & 12 \\
\hline Beïnvloed & 6 & 11 & 24 & 35 & 24 \\
\hline Totaal & 6 & 13 & 32 & 34 & 15 \\
\hline
\end{tabular}

Bron: Enquête onder MBO-gediplomeerden

Gezien de jongeren de exitgesprekken als (heel) nuttig ervaren hebben, is het van interesse om te zien of de jongeren aangeven of ze dezelfde keuzes hadden gemaakt als ze geen gesprek hadden gehad. Tegelijkertijd is het interessant om te kijken of degenen die geen gesprek hebben gehad denken dat ze door een gesprek tot een andere keuze gekomen waren. Tabel 3.12 geeft de antwoord op deze 'what-if' vragen die aan de respondenten gesteld zijn.

In eerste instantie kijken we naar de groep die op moment van enquête met een vervolgopleiding bezig is. Van de totale groep die een gesprek heeft gehad zou $95 \%$ ook zonder gesprek met een vervolgopleiding bezig zijn en $5 \%$ denkt dat ze dan niet in een vervolgopleiding zouden zitten. Van degenen die ook zonder gesprek met een vervolgopleiding bezig zouden zijn, zal verder $98 \%$ met dezelfde studie bezig zijn en slechts $2 \%$ zou hoogstwaarschijnlijk met een andere opleiding gestart zijn.

Onderscheiden we binnen de groep die een gesprek heeft gehad verder tussen de groep die door het gesprek op een of de andere manier beïnvloedt is ( $27 \%$ van de jongeren die een gesprek heeft gehad) en degenen die niet beïnvloedt zijn (63\% van de jongeren die een gesprek heeft gehad) zien we een aantal interessante verschillen. Ten eerste,: bij de groep die door het gesprek beïnvloedt is, geeft $87 \%$ aan dat ze zonder gesprek naar verwachting ook met een vervolgopleiding bezig zouden zijn. ${ }^{31}$ Met andere woorden, $13 \%$ van hen zou zonder gesprek niet zijn gestart met een vervolgopleiding. Daarnaast geeft $23 \%$-punt van degenen die ook dan met een studie bezig zouden zijn aan dat ze zonder gesprek met een andere opleiding gestart zouden zijn. Onder de groep die niet door het gesprek beïnvloed is zijn de cijfers respectievelijk $97 \%$ en $2 \%$.

Op basis van deze cijfers kunnen we concluderen dat zo'n $5 \%$ van de respondenten die met een vervolgopleiding is gestart, dit zonder gesprek niet had gedaan en dat zo'n $7 \%$ weliswaar waren gaan doorleren maar een andere opleidingskeuze hadden gemaakt. Deze cijfers komen sterk overeen met de eerder in Tabel 3.9 gepresenteerde resultaten en lijken een matige invloed van exitgesprekken te laten zien.

De vraag is echter of daarmee de invloed van exitgesprekken niet onderschat wordt. De resultaten in Tabel 3.12 geven namelijk ook een andere inzicht: II\% van de totale groep

3I. Onder de groep die denkt dat ze zonder gesprek niet met een vervolgopleiding gestart waren, zitten wederom relatief veel jongeren afkomstig van het $\mathrm{MBO}$ niveau I. 
respondenten is momenteel bezig met een vervolgopleiding, heeft geen gesprek gehad en zou ook met gesprek een vervolgopleiding volgen;32 $50 \%$ van de totale groep respondenten is momenteel bezig met een vervolgopleiding, heeft een gesprek gehad en zou ook met een vervolgopleiding bezig zijn zonder gesprek. ${ }^{33}$ Met andere woorden, voor zo'n $60 \%$ van de respondenten geldt dat zij met of zonder gesprek een vervolgopleiding volgen zouden. Volgen we deze logica, dan betekent dat dat er van begin aan af slechts zo'n $40 \%$ van de respondenten te beïnvloeden valt. De $4-5 \%$ van de totale groep respondenten die dankzij het gesprek alsnog verder is gaan leren komt dan neer op zo'n Iо\% van de groep die te beïnvloeden valt.

Tabel 3.12

What if?

\begin{tabular}{|l|r|r|r|r|}
\hline & $\begin{array}{r}\text { Ja, ik zou nu 0ok } \\
\text { studeren }\end{array}$ & $\begin{array}{r}\text { Ja, doorleren en zelfde } \\
\text { studie (\%-punten) }\end{array}$ & $\begin{array}{r}\text { Ja, doorleren maar } \\
\text { andere studie } \\
\text { (\%-punten) }\end{array}$ & $\begin{array}{r}\text { Ja, ik zou nu aan het } \\
\text { doorleren zijn }\end{array}$ \\
\hline In vervolgstudie & $87 \%$ & $77 \%$-punt & $23 \%$-punt & $X$ \\
\hline Door gesprek beïnvloed & $97 \%$ & $98 \%$-punt & $2 \%$-punt & $X$ \\
\hline Niet door gesprek beïnvloed & $95 \%$ & $94 \%$-punt & $6 \%$-punt & $X$ \\
\hline Gesprek gehad: totaal & $90 \%$ & $92 \%$-punt & $8 \%$-punt & $X$ \\
\hline Geen gesprek gehad & & & \\
\hline
\end{tabular}

Bron: Enquête onder MBO gediplomeerdMBO-gediplomeerden

Aan het begin van dit hoofdstuk hebben we gesteld dat ongeveer $30 \%$ van de gediplomeerden meldt dat zij geen exitgesprek hebben gehad. ${ }^{34}$ : Bijna de helft van deze groep (44\%) meldt dat zij graag een dergelijk gesprek hadden gehad. Niet verrassend is dit aandeel bovengemiddeld hoog onder de groep respondenten die op moment van enquête werkzoekend is (67\% had achteraf gezien graag een gesprek gehad) en de groep die minder dan I2 uur per week werkt (55\%). Echter ook onder de groep die succesvol is op de arbeidsmarkt (de groep die minimaal I2 uur per week werkzaam is) meldt nog steeds zo'n $40 \%$ dat ze achteraf bezien graag zo'n gesprek hadden gehad. ${ }^{35}$

Aan de groep die geen gesprek heeft gehad is verder gevraagd of ze denken dat zo'n gesprek hun keuze om door te leren dan wel zich op de arbeidsmarkt aan te bieden zou hebben beïnvloed. Van de groep die zich op de arbeidsmarkt heeft aangeboden denkt I6\% dat het

32. Dit is gebaseerd op het resultaat dat $\mathrm{I} 2 \%$ van de totale groep respondenten in een vervolgopleiding zit zonder ze een gesprek heeft gehad en de uitkomst dat $90 \%$ van hen ook met gesprek met een vervolgopleiding bezig zou zijn.

33. Dit is gebaseerd op het resultaat dat $5 \mathrm{I} \%$ van de totale groep respondenten in een vervolgopleiding zit, een gesprek heeft gehad maar daardoor niet beïnvloedt is en de uitkomst dat $97 \%$ van hen ook zonder gesprek met een vervolgopleiding bezig zou zijn.

34. Van deze groep meldt overigens 8\%-punt dat de school wel een gesprek heeft aangeboden maar zij niet op dit aanbod zijn ingegaan.

35. Op basis van aanvullende analyses kunnen geen specifieke kenmerken buitenomnaast de specifieke arbeidsmarktsituatie geen specifieke kenmerken van respondenten die graag een gesprek hadden gehad vastgesteld worden welke de groep respondenten die graag een gesprek hadden gehad karakteriseert. 
gesprek ertoe had kunnen leiden dat zij alsnog hun onderwijscarrière voortgezet hadden. Vergelijkbaar met wat al eerder gemeld is, verschillen de antwoorden van jongeren die op moment van enquête minimaal I2 uur werkzaam zijn (I4\% denkt dat een gesprek ertoe had kunnen leiden dat ze alsnog verder waren gaan leren), jongeren die minder dan I2 uur werkzaam zijn (29\%) en jongeren die zich als werkzoekend typeren ( $17 \%)$.

Tot slot van dit hoofdstuk staan we nog bij een tweetal vragen stil. In eerste instantie analyseren we de arbeidsmarktpositie van de recent gediplomeerden waarbij we een onderscheid maken tussen degenen die op school een gesprek hebben gehad en degenen die geen gesprek hebben gehad. Gezien de arbeidsmarktpositie van recent gediplomeerden afkomstig van het $\mathrm{MBO}-\mathrm{BOL}$ in de regel sterk verschilt van de arbeidsmarktpositie van gediplomeerden van het MBO-BBL onderscheiden we de situatie ook direct voor deze twee typen van gediplomeerden. Tabel 3.I3 laat voor de respondenten het percentage zien van een drietal mogelijke uitkomsten:

- Minimaal I2 uur per week werkzaam

- Minder dan I2 uur per week werkzaam

- Werkzoekend ${ }^{36}$

De uitkomsten van Tabel 3.I3 bevestigen dat de gediplomeerden van het MBO-BOL inderdaad een moeilijkere transitie van het onderwijs naar de arbeidsmarkt kennen: het percentage gediplomeerden van het MBO-BOL dat minimaal i2 uur per week werkzaam is, is aanzienlijk lager dan het percentage gediplomeerden van het MBO-BBL dat minimaal I2 uur werkzaam is, en het percentage dat zich als werkzoekend typeert is onder de gediplomeerden van het MBO-BOL op moment van enquête meer dan twee keer zo hoog als onder de gediplomeerden van het MBO-BBL.

Wat de verschillen tussen de groep jongeren betreft die voorafgaand aan het betreden van de arbeidsmarkt een exitgesprek op school hebben gehad en de groep jongeren die dat niet had, komt naar voren dat onder de groep gediplomeerden van het MBO-BOL die een gesprek heeft gehad het percentage dat meer dan I2 uur per week werkzaam is, licht hoger is en tegelijkertijd het percentage dat werkzoekend is licht lager is. Onder de groep gediplomeerden van het MBO-BBL die een gesprek heeft gehad verschillen de arbeidsmarktuitkomsten niet van de groep gediplomeerden die geen gesprek heeft gehad. ${ }^{37}$

36. Het is van groot belang om hierbij aan te geven dat werkzoekend niet overeen dient te komen met werkloosheid zoals gebruikelijk gedefinieerd. In de gebruikelijke definitie worden personen die minder dan I2 uur werken en actief op zoek zijn naar werk eveneens als werkloos gedefinieerd. Daarnaast zijn in de basis die voor bovenstaande tabel gebruikt wordt ook jongeren meegenomen die op moment van enquête noch werkzaam, noch werkzoekend zijn en daarmee formeel niet tot de beroepsbevolking behoren.

37. De uitkomsten van multivariate analyses waarin voor achtergrondkenmerken gecontroleerd is, bevestigen deze uitkomsten. Weliswaar slechts op IO\% significantie niveau is daarin zichtbaar dat bij jongeren afkomstig van het MBO-BOL de kans om minimaal I2 uur per week werkzaam te zijn positief is beïnvloedt door een exitgesprek. Bij jongeren afkomstig van het $\mathrm{MBO}-\mathrm{BBL}$ is dit effect niet zichtbaar. De analyses verder bevestigen verder de resultaten van andere publicaties, namelijk dat de kans om I2 uur per week werkzaam te zijn toeneemt met het opleidingsniveau, en dat jongeren van niet-westerse afkomst een kleinere kans hebben om I2 uur per week werkzaam te zijn dan autochtonen. Deze resultaten gelden zowel voor jongeren met een MBO-BOL diploma alsmede voor jongeren met een MBO-BBL diploma. 
Tabel 3.13

Arbeidsmarktpositie van recent gediplomeerde MBO-ers

\begin{tabular}{|l|r|r|r|r|} 
& \multicolumn{2}{|c|}{ MBO-BOL } & \multicolumn{2}{c|}{ MBO-BBL } \\
& Gesprek: ja & Gesprek: Nee & Gesprek: ja & Gesprek: nee \\
\hline$>12$ uur werkzaam & $66 \%$ & $61 \%$ & $89 \%$ & $91 \%$ \\
\hline$<12$ uur werkzaam & $10 \%$ & $10 \%$ & $1 \%$ & $2 \%$ \\
\hline Werkzoekend & $20 \%$ & $25 \%$ & $8 \%$ & $7 \%$ \\
\hline
\end{tabular}

Bron: Enquête onder MBO-gediplomeerden

Voor de groep die op moment van enquête met een vervolgstudie bezig is, analyseren we tot slot hun plannen tot de zomer van 20I4. Tabel 3.I4 laat in deze context de drie belangrijkste antwoord categorieën zien:

- Ik ga verder met mijn opleiding

- Ik ga van opleiding wisselen

- $\quad$ Ik ga stoppen met mijn opleiding

De uitkomsten geven een lichte indicatie van een positieve invloed van een gesprek. Het aandeel respondenten dat van plan is om met de gekozen vervolgopleiding verder te gaan is marginaal hoger onder de groep die voorafgaand een exitgesprek op de oude MBO school hebben gehad $^{38}$. Zo is $90 \%$ van de verder lerende MBO-BOL gediplomeerden dat een gesprek heeft gehad van plan om met de vervolgopleiding verder te gaan tegenover $83 \%$ die geen gesprek hebben gehad. Bij de groep gediplomeerden van het MBO-BBL is het verschil weliswaar aanzienlijk kleiner maar met $+3 \%$-punt nog steeds in voordeel van de groep die een exitgesprek had voorafgaand aan het starten van de vervolgopleiding.

Tabel 3.14

Plannen tot zomer 2014 van recent gediplomeerde MBO-ers die door zijn gaan leren

\begin{tabular}{|l|r|r|r|r|}
\hline & \multicolumn{1}{|c|}{ MBO-BOL } & \multicolumn{2}{c|}{ MBO-BBL } \\
\hline Ik ga verder met mijn studie & Gesprek: ja & Gesprek: Nee & Gesprek: ja & Gesprek: nee \\
\hline Ik ga van opleiding wisselen & $90 \%$ & $83 \%$ & $85 \%$ & $82 \%$ \\
\hline Ik ga stoppen met mijn opleiding & $2 \%$ & $2 \%$ & 0 & $0 \%$ \\
\hline
\end{tabular}

Bron: Enquête onder MBO-gediplomeerden

\subsubsection{Conclusies 'De waarde van Exitgesprekken: Het informele circuit}

- Ook binnen het informele circuit komt naar voren dat exitgesprekken breed door bijna het hele $\mathrm{MBO}$ gevoerd zijn. Daarbij lijkt er niet selectief te zijn omgegaan met het inzetten van exitgesprekken; in de analyses kan niet worden aangetoond dat er bepaalde groepen van gediplomeerden met bepaalde achtergrondken-

38. De uitkomsten van multivariate analyses waarin voor achtergrondkenmerken gecontroleerd is, bevestigen deze uitkomsten. Weliswaar slechts op IO\% significantie niveau is daarin zichtbaar dat bij jongeren afkomstig van het MBO-BOL de kans dat zij aangeven 'verder te gaan met studie' positief beïnvloedt wordt door een exitgesprek. Bij jongeren afkomstig van het MBO-BBL is dit effect niet zichtbaar. 
merken zijn die een grotere dan wel juist kleinere kans hebben om een exitgesprek te hebben gehad.

- Indien scholen vanwege budget beperkingen (tijd, geld) toch gedwongen zijn om keuzes te maken aan wie ze een exitgesprek aanbieden, is het echter aan te raden om de exitgesprekken te richten op gediplomeerden van niveau i en 2, dan wel op jongeren van niet-westerse afkomst. Dit zijn namelijk de groepen waarop exitgesprekken in het algemeen meer van invloed zijn. De invloed op keuzes ten aanzien van doorleren of welke studie is zeer gering op de hogere niveaus.

- Exitgesprekken hebben doorgaans een positieve invloed. Gediplomeerden hebben de exitgesprekken doorgaans als (heel) nuttig ervaren, en het percentage respondenten dat van plan is om met de gekozen vervolgopleiding verder te gaan is marginaal hoger onder de groep die voorafgaand een exitgesprek op de $\mathrm{MBO}$ school hebben gehad.

- Exitgesprekken zouden aangeboden kunnen worden aan een grotere groep gediplomeerden. Van de respondenten die geen gesprek hebben gehad (zo'n 30\%) geeft bijna de helft aan dat ze wel graag een gesprek gehad zouden hebben. Van degenen die geen gesprek hebben gehad en niet zijn gaan doorstuderen, denkt I6\% dat als ze wel een gesprek zouden hebben gehad, ze alsnog zouden zijn gaan doorleren. 


\section{4 \\ OMBUIGINGSGESPREKKEN/ STUDIEKEUZEGESPREKKEN}

\subsection{Inleiding}

De doelstelling van de voorliggende evaluatie is om vast te stellen of de invoering van het School Ex 2.0 programma, en daarbij specifiek de Exitgesprekken en Ombuigingsgesprekken, de gewenste effecten heeft bereikt. In dit hoofdstuk staan we stil bij de Ombuigingsgesprekken. Schema 4.I biedt een korte schematische samenvatting van de opzet van ombuigingsgesprekken zoals deze in het kader van het School Ex 2.0 programma bedoeld zijn (zie p. 47). Een aantal relevante resultaten afkomstig van de enquête onder de scholen worden in paragraaf 4.I.I gepresenteerd.

Zoals in hoofdstuk 2 nader uitgelegd zullen de analyses in dit hoofdstuk vooral betrekking hebben op de enquête onder de jongeren en daarmee alleen op de invloed van het informele circuit van ombuigingsgesprekken dat via de algemene intake-/studiekeuzegesprekken plaatsvindt. Achtereenvolgend staan we daarom in dit hoofdstuk stil bij de vragen:

- Wie heeft de studiekeuze op school besproken?

- Wie is er van studiekeuze gewisseld?

- Hebben studiekeuzegesprekken de studiekeuze van de studiewisselaars naar eigen zeggen beïnvloed?

- Wat is de rol van de Ingeschatte arbeidsmarktperspectieven van de eerste en uiteindelijke studiekeuze?

\subsubsection{Ombuigingsgesprekken - Enquête onder scholen}

Op basis van de antwoorden van de scholen is het wederom mogelijk om een vierdeling te maken, zoals deze ook in het kader van de evaluatie van de Exitgesprekken aan bod is gekomen:

Ervaren scholen met continue aanpak: Deze scholen geven aan zowel bij de aanmeldingen voor het schooljaar 2013/20I4 ombuigingsgesprekken te hebben gevoerd, als ook 
voor aanmeldingen in voorgaande schooljaren (20IO/2OII, 20II/2OI2 en/of 20I2/2OI3). De procedure en/of het percentage leerlingen dat ombuigingsgesprekken kreeg is daarbij naar eigen zeggen onveranderd gebleven.

Ervaren scholen met nieuwe aanpak: Deze scholen geven aan zowel bij de aanmeldingen voor het schooljaar 2013/20I4 ombuigingsgesprekken te hebben gevoerd, als ook voor aanmeldingen in voorgaande schooljaren (20IO/2OII, 2OII/2OI2 en/of 20I2/20I3). De procedure en/of het percentage leerlingen dat ombuigingsgesprekken kreeg is daarbij wel veranderd.

Nieuwkomers: Deze scholen hebben bij de aanmeldingen voor 2013/20I4 individuele ombuigingsgesprekken gevoerd, maar niet bij de aanmeldingen in voorgaande schooljaren.

Geen gesprekken: Deze scholen hebben geen ombuigingsgesprekken gevoerd, noch bij de aanmeldingen voor 2013/20I4, noch voor eerdere schooljaren.

Van de 276 school-domein combinaties die de vragenlijst hebben ingevuld, geven er 135 aan dat ze bij de aanmeldingen voor het schooljaar 2013/20I4 geen ombuigingsgesprekken hebben gevoerd (zie Tabel 4.I). Bij de overige I4I combinaties zijn er wel ombuigingsgesprekken gevoerd met de aanmeldingen voor het schooljaar 2013/20I4.

\section{Tabel 4.1}

Domein-school combinaties per type

\begin{tabular}{|l|r|r|}
\hline Type & Aantal school-domein comb. & Percentage \\
\hline Ervaren met continue aanpak & 47 & 17 \\
\hline Ervaren met nieuwe aanpak & 37 & 13 \\
\hline Nieuwkomer zonder ervaring & 57 & 21 \\
\hline Geen gesprekken & 135 & 49 \\
\hline Bron: Enquête onder scholen & &
\end{tabular}

Aangezien bijna 50\% van de respondenten aangeeft dat er in hun domein geen ombuigingsgesprekken hebben plaatsgevonden, is het interessant om kort stil te staan bij de antwoorden op de vraag wat de reden hiervoor was (zie Tabel 4.2). We doen daarbij al vooraf een verdergaande selectie, door de focus te leggen op de antwoorden van schooldomein combinaties die niet aangegeven hebben dat een reden voor het niet voeren van gespreken was "We hadden geen aanmeldingen voor beroepen met minder gunstige arbeidsmarktperspectieven". Immers, indien er geen aanmeldingen voor beroepen met minder gunstige arbeidsmarktperspectieven zijn is er geen druk om ombuigingsgesprekken te voeren. 


\section{Tabel 4.2}

Waarom hebben domein-school combinaties in 2013/2014 geen gesprekken gevoerd? (meerdere antwoorden mogelijk)

\begin{tabular}{|l|r|}
\hline Reden & $\%$ \\
\hline Geen tijd & 25 \\
\hline Geen nut & 23 \\
\hline Gaat ten koste van de instroom van de opleiding & 21 \\
\hline
\end{tabular}

Bron: Enquête onder scholen

Het meest opvallende resultaat in Tabel 4.2 is de uitkomst dat een op de vijf schooldomein combinaties aangeeft dat de reden hiervoor was 'gaat ten koste van de instroom van de opleiding'. Dit is een opvallend argument omdat ombuigingsgesprekken per definitie plaatsvinden bij opleidingen met slechte perspectieven, en het hier derhalve om een verminderde instroom in een opleiding met slechte perspectieven zou gaan: en dat is juist precies waar ombuigingsgesprekken voor dienen. In andere woorden zou, volgens de doelstelling van het School Ex programma, een verminderde instroom in opleidingen met slechte perspectieven nooit een argument mogen zijn om geen ombuigingsgesprekken te voeren. In een op de vier gevallen speelden 'tijdrestricties' een belangrijke rol. Dit geeft een indicatie dat er in de toekomst nog ruimte zou kunnen zijn voor uitbreiding van het School Ex programma, mits - in tegenstelling tot het de situatie in 2013 - scholen vroegtijdig over de opzet en het belang van ombuigingsgesprekken geïnformeerd worden.

Hoeveel instromers vanuit het VMBO hebben volgens de scholen een ombuigingsgesprek gehad en hoeveel van hen zijn beïnvloed? Tabel 4.3 laat zien dat in bijna een op de twee school-domein combinaties (43\%) waarvoor informatie beschikbaar is maximaal IO\% van de totale instromers een ombuigingsgesprek heeft gehad. Nog eens $27 \%$ van de van de school-domein combinaties meldt dat tussen de IO-20\% van de instroom een gesprek heeft gehad en $25 \%$ meldt dat ombuigingsgesprekken bij 20-30\% van de instroom plaats heeft gevonden.

\section{Tabel 4.3}

Aandeel van totale instroom dat een gesprek heeft gehad (\%) en aandeel dat beïnvloed is

\begin{tabular}{|l|r|r|}
\hline & Aandeel dat gesprek heeft gehad & Aandeel dat beïnvloed is \\
\hline $0-10 \%$ & 46 & 26 \\
\hline $10-20 \%$ & 9 & 12 \\
\hline $20-30 \%$ & 35 & 9 \\
\hline $30-40 \%$ & 0 & 14 \\
\hline $40-50 \%$ & 0 & 3 \\
\hline $50-60 \%$ & 2 & 13 \\
\hline $60-90 \%$ & 0 & 10 \\
\hline $90-100 \%$ & & 20 \\
\hline
\end{tabular}

Bron: Enquête onder scholen 
Een duidelijk gevarieerder beeld komt naar voren als we kijken naar het aandeel instromers dat een gesprek heeft gehad en volgens de scholen daardoor is beïnvloed (zie Tabel 4.3). Nadere analyses op het niveau van school-domein combinaties zijn daarbij niet in staat om de verschillen te kunnen verklaren door verschillen in de opzet van de gesprekken (bijvoorbeeld duur van het gesprek, het aantal gesprekken dat gemiddeld heeft plaatsgevonden, de persoon waarmee gesproken is of de thema's die aan bod zijn gekomen). Op basis van de uitkomsten gepresenteerd in Tabel 4.3 kan daarmee een inschatting gemaakt worden van het aandeel jongeren dat 'omgebogen' is. Afhankelijk van de basis die aan de berekening ten gronde ligt (bijvoorbeeld dat met Io\% gerekend wordt indien de antwoord IO- $20 \%$ was of dat met $20 \%$ gerekend wordt) varieert het aandeel omgebogen daarmee tussen de $4 \%$ en IO\%.

De antwoorden van de scholen laten verder zien dat tijdens de gesprekken verschillende thema's aan bod zijn gekomen. Zo meldt bijna $70 \%$ van de school-domein combinaties dat er in de gesprekken over de lange termijn plannen van de jongeren gesproken is, geeft $82 \%$ aan dat over de kansen op het vinden van een baan met de gekozen opleiding gesproken is en zijn in $72 \%$ van de gevallen de capaciteiten van de jongeren aan bod gekomen. Tot slot geeft $73 \%$ van de respondenten aan dat mogelijke vervolgopleidingen een onderdeel van het gesprek uitmaakten.

Aangezien de arbeidsmarktperspectieven van een beroep van belang zijn tijdens de gesprekken, is het interessant om te zien welke informatie de scholen gebruiken om de arbeidsmarktperspectieven vast te stellen. Informatie afkomstig van OCW wordt bij ongeveer de helft van de gevallen vermeld als gebruikte informatie. Het aantal beschikbare stages speelt bij 55\% van de school-domein combinaties een belangrijke rol bij het bepalen van arbeidsmarkperspectieven en eveneens zo'n 50\% meldt dat zij de website www.kansopwerk.nl raadplegen.

Tot slot staan we nog kort stil bij twee oordeel vragen die gesteld zijn aan de respondenten van de scholen. De eerste betreft de vraag of ombuigingsgesprekken nuttig waren en de tweede de vraag of de ombuigingsgesprekken de leerlingen naar opleidingen met betere arbeidsmarktperspectieven hebben geleid. Terwijl de eerste vraag overwegend positief beantwoord wordt ( $87 \%$ vindt de ombuigingsgesprekken [zeer] nuttig) is men wat de tweede vraag betreft minder positief. 'Slechts' $37 \%$ denkt namelijk dat ombuigingsgesprekken de leerlingen inderdaad naar opleidingen met betere arbeidsmarktperspectieven hebben geleid. 


\section{Schema 4.1}

Conceptueel model van de beleidstheorie van ombuigingsgesprekken

MBO-scholen evalueren het opleidingsaanbod

(van zichzelf en andere scholen) m.b.t.

arbeidsmarktperspectieven in de regio

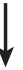

MBO-scholen voeren ombuigingsgesprekken met

VMBO'ers die zich hebben aangemeld voor opleidingen

met slechte arbeidsmarktperspectieven<smiles>[Te][Te]</smiles>

VMBO'ers die zich aangemeld hebben voor opleidingen met slechte

arbeidsmarktperspectieven hebben kennis van deze slechte perspectieven, en

van de (betere) arbeidsmarktperspectieven van andere opleidingen

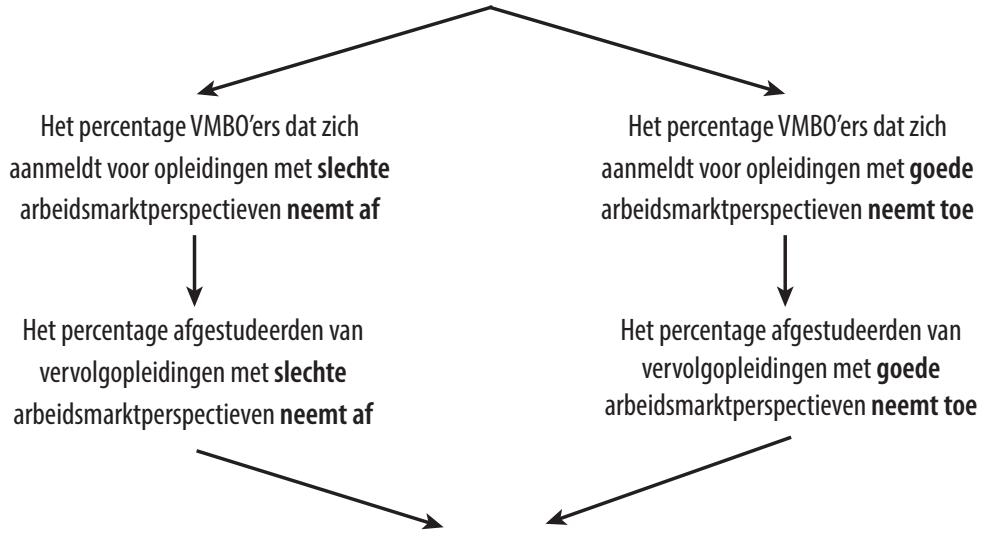

Jeugdwerkloosheid

lange termijn daalt

\subsection{Wie heeft de studiekeuze besproken?}

Een ruime meerderheid (66\%) van de respondenten die in het schooljaar 2013/20I4 met een MBO-BOL opleiding zijn gestart, geeft aan dat ze hun opleidingskeuze besproken hebben op hun huidige MBO-school. ${ }^{39}$ Tabel 4.4 laat zien dat het aandeel jongeren dat de studiekeuze heeft besproken in de regel niet sterk verschilt tussen de VMBO sector

39. Dit hoeft overigens niet te betekenen dat $34 \%$ geen studiekeuzegesprek heeft gehad. Het is goed mogelijk dat als respondenten een gesprek hebben gehad op een andere vestiging (of wellicht zelfs een ander gebouw) dan waar ze uiteindelijk hun lessen volgen, ze hebben aangegeven dat dat gesprek niet op hun huidige MBO-school heeft plaatsgevonden, terwijl dat formeel wel het geval was. 
waarvan men het diploma heeft behaald, waarbij het aandeel bij de jongeren afkomstig van de VMBO sectoren Economie en Gezondheidszorg licht boven het gemiddelde ligt. Eveneens relatief kleine verschillen zijn te zien tussen jongeren die met een opleiding op MBO-BOL niveau I/2 en jongeren die met een opleiding op MBO-BOL niveau 3/4 gestart zijn. Tot slot laat Tabel 4.4 ook zien dat de verschillen relatief klein zijn als we naar de opleidingssector kijken waar men ingestroomd is.

\section{Tabel 4.4}

Aandeel respondenten dat aangeeft studiekeuze besproken te hebben

\begin{tabular}{|l|l|}
\hline VMBO sector waarvan afkomstig & $\%$ \\
\hline Theoretische leerweg & $65 \%$ \\
\hline Economie & $68 \%$ \\
\hline Gecombineerde richtingen & $68 \%$ \\
\hline Landbouw & $62 \%$ \\
\hline Techniek & $63 \%$ \\
\hline Zorg \& Welzijn & $72 \%$ \\
\hline MBO-BOL niveau waarop ingestroomd & \\
\hline Niveau 1/2 & $69 \%$ \\
\hline Niveau 3/4 & $66 \%$ \\
\hline MBO-BOL sector waarin ingestroomd & \\
\hline Landbouw & $73 \%$ \\
\hline Techniek & $62 \%$ \\
\hline Economie & $65 \%$ \\
\hline Gezondheidszorg & $68 \%$ \\
\hline Gedrag en Maatschappij & $72 \%$ \\
\hline MBO-BOL totaal & $66 \%$ \\
\hline
\end{tabular}

In figuur 4.I is per MBO-school met ten minste 20 respondenten weergegeven wat het percentage respondenten is dat aangeeft op de $\mathrm{MBO}$-school een gesprek over de opleidingskeuze te hebben gehad. Hierin is te zien dat bij vrijwel alle scholen ten minste de helft van de respondenten aangeeft een studiekeuzegesprek te hebben gehad. Bij de meeste scholen is het zo'n 60-70\% van de respondenten.

De vraag is echter of deze verschillen blijven bestaan als er voor verdergaande kenmerken van de jongeren gecontroleerd wordt en in hoeverre precies deze kenmerken van belang zijn bij de vraag 'welke jongeren hebben een studiekeuzegesprek gehad?'. Om dit nader te analyseren is via een multivariate analyse de kans geschat dat een respondent meldt dat hij of zij de studiekeuze in een of meerdere gesprekken met iemand van de huidige school besproken heeft (Zie bijlage 5 voor de volledige resultaten). Hierbij wordt gecontroleerd voor o.a. de gevolgde leerweg in het $\mathrm{VMBO}$, de gevolgde richting in het $\mathrm{VMBO}$ alsmede voor leeftijd, geslacht, leerweg en prestaties in het VMBO, het opleidingsniveau van de 
vader, eventuele problemen m.b.t. functioneren, en preferenties m.b.t. arbeidsmarkt en onderwijs.

\section{Figuur 4.1}

Percentage respondenten dat aangeeft een studiekeuzegesprek te hebben gehad, per ROC/AOC (minimaal 20 respondenten)

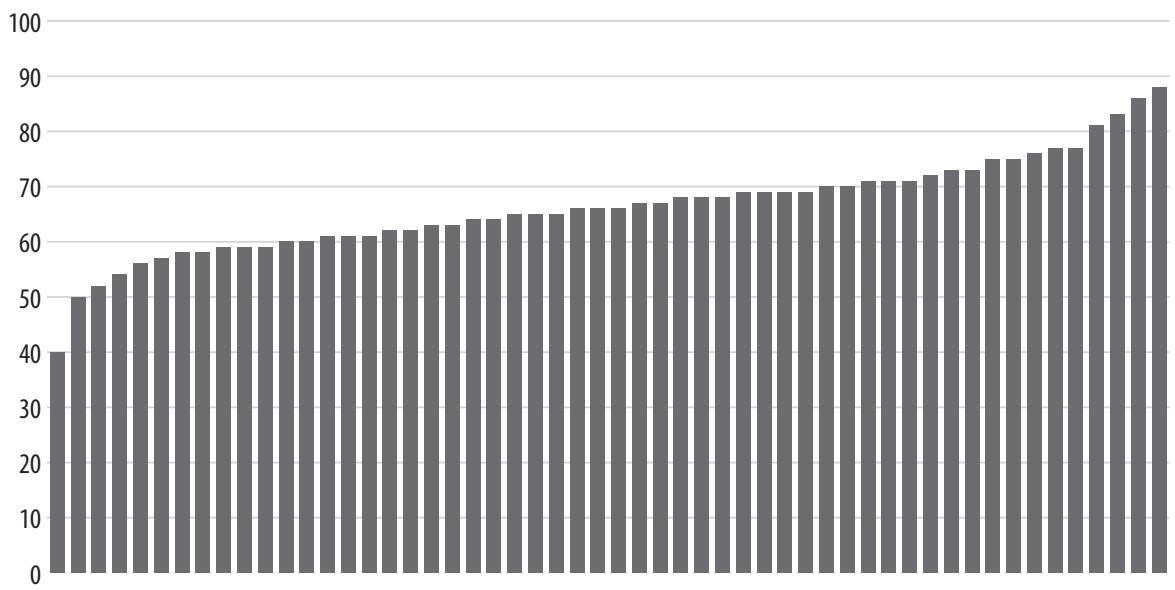

Bron: Enquête onder MBO-BOL instroom

De uitkomsten van de multivariate analyses bevestigen in eerste instantie het in tabel 4.4 gepresenteerde beeld dat de respondenten van de VMBO sectoren Economie en Zorg \& Welzijn relatief de grootste kans hebben om een studiekeuzegesprek te hebben gehad. Gezien het gros van deze jongeren binnen de sector doorstromen naar een MBO-BOL opleiding, spoort deze uitkomst met de relatief slechte arbeidsmarktperspectieven voor $\mathrm{MBO}$ Economie opgeleiden in de volgende jaren en in het geval van MBO Gezondheidszorg relatief slechte arbeidsmarktkansen van gediplomeerden afkomstig van niveau I en 2. Voor deze jongeren kunnen dan ook studiekeuzegesprekken van groot belang zijn.

Naast het effect op basis van de gevolgde VMBO sector, laat de analyse geen verdere effecten afkomstig van de gevolgde VMBO-opleiding, of de prestaties tijdens de VMBOopleiding zien. Ook andere achtergrondkenmerken van de jongeren (bijvoorbeeld opleidingsniveau van de ouders of de ervaren problemen in leefgebieden zoals de thuissituatie of drugsgebruik) lijken niet bepalend te zijn voor de vraag of men de studiekeuze op school besproken heeft of niet. Het enige individuele achtergrondkenmerk dat een effect heeft, is de etnische achtergrond van de respondent. Jongeren van niet-westerse afkomst hebben namelijk een significant kleinere kans (-7\%-punt) dat zij de studiekeuze besproken hebben, maar ook van hen heeft $60 \%$ een studiekeuzegesprek gehad. 
Tot slot laat de analyse zien dat jongeren die melden dat ze hun studiekeuze op de MBO school besproken hebben vaker melden dat de MBO-school volgens hen naast de gesprekken nog andere activiteiten ondernomen heeft om te helpen bij het maken van de studiekeuze (+8\%-punt). Dit zou ermee te maken kunnen hebben dat er tijdens het gesprek op deze informatiebronnen is gewezen, of dat jongeren voor aanvang (wellicht ter voorbereiding) van het gesprek zelfstandig studiekeuzemateriaal hebben verzameld. Hierdoor zijn degenen die geen studiekeuzegesprek hebben gehad wellicht minder op de hoogte van het beschikbare studiekeuzemateriaal.

$O p$ basis van deze analyses kunnen we dan ook vaststellen dat studiekeuzegesprekken binnen $M B O$-scholen op grote schaal plaatsvinden en dat $M B O$-scholen daarbij niet selectief zijn in wie er een studiekeuzegesprek krijgt of niet.

\subsection{Wie is er van studiekeuze gewisseld?}

De vraag is natuurlijk wat de uitkomst van het studiekeuzegesprek is. Met andere worden, kunnen jongeren tijdens zo'n gesprek nog beïnvloed worden of niet? In de voorliggende evaluatie is dit immers een van de centrale vraagstellingen. Om hiervan een beeld te krijgen, is in eerste instantie aan de jongeren gevraagd aan te geven of hun huidige MBO-BOL opleiding ook (een van) hun eerste keuze(s) was (zie tabel 4.5).

\section{Tabel 4.5}

Antwoorden van respondenten op de vraag: Was je huidige opleiding ook (een van) je eerste keuze(s)? (\%)

\begin{tabular}{l|l|}
\hline Ja, de opleiding die ik nu volg was ook mijn eerste keuze & 55.5 \\
\hline $\begin{array}{l}\text { Ja, ik wist in eerste instantie nog niet zeker welke opleiding ik wilde gaan doen maar de opleiding die ik nu volg is wel één van } \\
\text { de opleidingen waar ik al interesse in had }\end{array}$ & 27.9 \\
\hline Nee, ik wilde in eerste instantie een andere opleiding gaan volgen & 16.6 \\
\hline Bron: Enquête onder MBO-BOL instroom
\end{tabular}

Ruim de helft (56\%) antwoordde dat de opleiding die ze nu volgen ook de eerste keuze was: dit is de groep die naar eigen zeggen niet van studiekeuze gewisseld is, en daardoor ook niet het idee zullen hebben omgebogen te zijn. Van de respondenten geeft $17 \%$ aan dat ze in eerste instantie een andere opleiding hadden willen gaan volgen dan de opleiding waar ze nu mee bezig zijn. Dit betekent dat zij naar eigen zeggen van studiekeuze zijn gewisseld, waarbij het uiteraard de vraag is of dit (volgens henzelf) het gevolg is geweest van een gesprek op school over de studiekeuze. Ruim een kwart (28\%) geeft aan dat ze in eerste instantie nog niet zeker wisten welke opleiding ze wilden gaan doen, maar dat de opleiding die ze nu volgen wel één van de opleidingen was waar ze al interesse in hadden.

Voordat we navolgend in meer detail stilstaan bij de drie groepen, is het belangrijk om op basis van Tabel 4.5 alvast te concluderen dat bijna een op de twee VMBO-gediplomeerden die in het $M B O-B O L$ instroomt niet bij zijn eerste en enige keuze blijft, wat een duidelijke indicatie is 
dat jongeren vaak twijfelen over hun studiekeuze en daarom in het beginsel ook door studiekeuzegesprekken beïnloedbaar zijn.

Voor de groep 'studietwijfelaars' is op basis van de vragenlijst niet vast te stellen of ze werkelijk van studiekeuze gewisseld zijn of niet. Daardoor is het ook niet vast te stellen of ze 'omgebogen' zijn tijdens een studiekeuzegesprek en zullen ze in de navolgende analyses buiten beschouwing gelaten worden. Om te controleren of we daarmee een selecte groep van respondenten verliezen, is op basis van multivariate analyses nagegaan of de groep 'studietwijfelaars' andere kenmerken heeft dan de twee andere groepen. De uitkomsten hiervan laten zien dat dit in de regel niet het geval is. Het enige aspect waarop 'studietwijfelaars' verschillen van de andere twee groepen is dat zij zich eerder typeren als jongeren die zich bij het nemen van beslissing laten adviseren door anderen dan dat ze de beslissing zelfstandig nemen.

Ondanks dat voor de groep 'studietwijfelaars' op basis van de vragenlijst niet eenduidig vastgesteld kan worden of ze naar aanleiding van een studiekeuzegesprek op de MBO-school van studie zijn gewisseld of niet, kan wel nagegaan worden of ze a) door het gesprek in algemene zin beïnvloed zijn en b) hoe nuttig ze het gesprek ervaren hebben. Tabel 4.6 laat de antwoorden op deze twee vragen zien en vergelijkt daarbij direct de groep 'studietwijfelaars' met de groep 'studiewisselaars' en de groep die bij de eerste en enige keuze is gebleven. De uitkomsten laten zien dat wat deze twee aspecten betreft de groep 'studietwijfelaars' sterk vergelijkbaar is met de groep 'studiewisselaars'. De groep die bij de eerste (en enige) studiekeuze is gebleven scoort op beide onderdelen iets lager.

Tabel 4.6

Invloed van gesprek en nut van gesprek

\begin{tabular}{|l|r|r|r|}
\hline & Studietwijfelaar & Studiewisselaar & Vaste studiekeuze \\
\hline \% In sterke mate beïnvloed & $37 \%$ & $39 \%$ & $30 \%$ \\
\hline \% Dat gesprek heel nuttig vond & $65 \%$ & $68 \%$ & $62 \%$ \\
\hline
\end{tabular}

Bron: Enquête onder MBO-BOL instroom

We komen nu terug op onze oorspronkelijk vraag, namelijk 'wie is van studiekeuze gewisseld en wie niet?', waarbij we zoals gemeld de groep studietwijfelaars buiten beschouwing laten.

In multivariate analyses (zie Bijlage 6) is onderzocht welke factoren van invloed zijn of respondenten al dan niet aangeven van studiekeuze te zijn gewisseld. In de analyses is gecontroleerd voor persoonlijke kenmerken (leeftijd, geslacht, etniciteit, arbeidsmarkten onderwijsvoorkeuren, ervaren problemen op enkele leefgebieden), voor kenmerken van de afgeronde VMBO-opleiding (studierichting, leerweg, het gemiddelde eindcijfer), het opleidingsniveau van de vader, of er al dan niet een studiekeuzegesprek heeft plaatsgevonden en zo ja enkele kenmerken van dat gesprek (met wie, wanneer, hoe lang en hoe vaak er is gesproken, wat er is besproken, hoe het gesprek is ervaren). Ook is er gecontroleerd voor de eigen ingeschatte arbeidsmarktperspectieven van de eerste opleidingskeuze ${ }^{40}$.

40. Voor degenen die nu de opleiding volgen die ook hun eerste keuze was, zijn de ingeschatte arbeidsmarktperspectieven van de eerste opleidingskeuze gelijk aan de ingeschatte arbeidsmarktperspectieven van hun huidige opleiding. 
De ingeschatte arbeidsmarktperspectieven van de eerste opleidingskeuze. Respondenten die denken dat het (heel) moeilijk zou zijn om een baan te vinden met het diploma van hun eerste opleidingskeuze op zak, hebben een significant grotere kans om van studiekeuze te zijn gewisseld (+19\%-punt) dan degenen die denken dat het niet moeilijk maar ook niet makkelijk zou zijn om een baan te vinden met dat diploma.

Gezien de doelstelling van het School Ex 2.0 programma is dit een cruciaal resultaat dat de onderliggende assumptie van het programma ondersteunt, namelijk dat jongeren die kennis hebben van slechte arbeidsmarktperspectieven eerder van studie zullen wisselen. Gezien de relevantie van deze uitkomst, is het van belang om nader stil te staan bij de vraag of dit resultaat voor verschillende sub-groepen van de onderzochte populatie op vergelijkbare manier geldt of niet.

Aanvullende analyses laten zien dat

- bij jongeren die instromen in een MBO-BOL opleiding op niveau 3 of 4 het al dan niet wisselen van studiekeuze sterker afhankelijk is van de arbeidsmarktperspectieven dan bij jongeren die instromen in een MBO-BOL opleiding op niveau I en 2. Redenen hiervoor kunnen onder andere zijn dat a) de keuze tussen mogelijke opleidingen bij jongeren die uiteindelijk op niveau 3 of 4 instromen groter is of b) dat de variatie in arbeidsmarktperspectieven tussen opleidingen op niveau 3 en 4 groter is dan tussen opleidingen op niveau I en 2.

- de invloed van de arbeidsmarktkansen vergelijkbaar is onder de jongeren met nietwesterse afkomst en autochtone jongeren ondanks dat de arbeidsmarktkansen van jongeren van deze twee groepen sterk verschillen (zie SCP, 20I4) ${ }^{4 \mathrm{I}}$.

Gesprek (aantal, duur en inhoud). Vergelijkbaar met onze analyses van de exitgesprekken zien we dat het überhaupt al dan niet hebben gehad van een studiekeuzegesprek geen significante invloed heeft op een studiekeuzewissel, maar dat er een correlatie te vinden is tussen de opzet en inhoud van het gesprek ${ }^{42}$. Respondenten die van studiekeuze gewisseld zijn hebben in de regel meer gesprekken gehad en de gemiddelde duur van een gesprek was ook langer. Met andere worden, jongeren wisselen niet op basis van één kort gesprek, maar om de weloverwogen studiekeuzewissel te maken zijn meerdere gesprekken van gemiddeld minimaals tussen de Io en 30 minuten (maar nog beter van meer dan 30 minuten) nodig. Daarnaast vinden we, niet verrassend, dat het onderwerp van het gesprek dat aan bod is gekomen verschilt tussen de groep die wel van studiekeuze gewisseld is en de groep die dat niet heeft gedaan. Zo vinden we een negatieve correlatie tussen degenen die aangeven dat tijdens het studiekeuzegesprek de toekomstplannen voor de lange termijn en/of de opleiding waarvoor ze zich hadden aangemeld was besproken en de kans om van studiekeuze gewisseld te zijn. Een positieve correlatie vinden we tussen degenen die aangeven dat er (ook) andere mogelijke opleidingen zijn besproken en de

4I. SCP (2014), Jaarrapport Integratie, Den Haag.

42. Zoals eerder vermeld is het mogelijk dat de opzet (aantal gesprekken, duur) of inhoud van het gesprek niet per se exogeen dient te zijn. Aanvullende analyses laten zien dat deze mogelijke endogeniteit echter geen invloed op de uitkomsten van de andere variabelen heeft. 
kans om van studiekeuze te zijn gewisseld. Interessant is dat wat de toekomstplannen voor de lange termijn betreft de uitkomst in lijn is met onze bevindingen met betrekking tot de exitgesprekken. Ook daar vonden we namelijk dat er een negatieve correlatie is tussen het bespreken van de lange termijn perspectieven en de kans om de oorspronkelijke idee te veranderen. Aanvullende analyses laten zien dat de arbeidsmarktperspectieven van de opleiding bij jongeren waarbij de lange termijn toekomstplannen aan bod zijn gekomen bij de beslissing om wel of niet van studiekeuze te wisselen en relatief minder sterke invloed kennen dan bij jongeren waarbij niet over de lange termijn perspectieven gesproken is. Dit zou erop kunnen duiden dat de korte termijn arbeidsmarktperspectieven vooral van belang zijn bij jongeren die zich nog niet druk maken over de lange termijn.

De motivatie voor het volgen van een opleiding. Hoe meer de respondenten vinden dat de stelling "Ik vind het belangrijk om een opleiding te doen waar ik een baan mee kan vinden" op zichzelf van toepassing is ten opzichte van de stelling "Ik vind het belangrijk om een opleiding te doen doe ik leuk vind", hoe vaker ze aangeven van studiekeuze te zijn gewisseld. Dit geeft aan dat niet alle leerlingen even ontvankelijk zullen zijn voor het argument dat ze wellicht beter wat anders zouden kunnen gaan studeren omdat de opleiding waarvoor ze zich hebben aangemeld slechte arbeidsmarktperspectieven heeft. Nadere analyses laten zien dat het eerder aan de orde gekomen effect van invloed door arbeidsmarktperspectieven versterkt wordt indien jongeren zichzelf typeren als iemand die een opleiding doet waarmee een baan gevonden kan worden.

Andere voorlichting. Als de respondent aangeeft dat de school, naast het aanbieden van individuele gesprekken met leerlingen, ook andere activiteiten heeft ondernomen om te helpen bij het maken van studiekeuzes, dan is de kans dat ze van studiekeuze gewisseld zijn kleiner. Dit heeft er waarschijnlijk mee te maken dat degenen die zich voorafgaand aan het gesprek het beste informeren, bij hun (weloverwogen) keuze blijven en dus niet van studiekeuze wisselen.

Ervaren problemen in leefgebieden. Jongeren die melden dat ze problemen in de thuissituatie kennen (problemen met familie/ouders/verzorgers) zijn eveneens vaker onder de studiewisselaars te vinden (+IO\%-punt). Dit kan erop wijzen dat deze groep jongeren van thuis uit minder steun hebben bij het maken de studiekeuze en daarom minder goed voorbereide studiekeuzes maken en deze sneller wisselen.

Tijdstip van studiekeuzegesprek. Respondenten die aangeven dat ze tijdens of na de zomervakantie (juli $\mathrm{t} / \mathrm{m}$ december 2013) een gesprek hebben gehad op school over hun studiekeuze, hebben een grotere kans om van studiekeuze te zijn gewisseld dan degenen die in april t/m juni 2013 hun studiekeuzegesprek gehad hebben. Dit hoeft zeker niet te betekenen dat het beter is om te wachten met het voeren van gesprekken, het is waarschijnlijker dat dit ermee te maken heeft dat de leerlingen die langer twijfelen zich later aanmelden op de $\mathrm{MBO}$-school en daarom eerder van keuze wisselen. 


\subsection{Hebben studiekeuzegesprekken de studiekeuze van de studiewisselaars naar eigen zeggen beïnvloed?}

Wellicht het meest interessant om te bestuderen is of degenen die een gesprek op school hebben gehad over hun studiekeuze, en die tevens aangeven dat hun huidige opleiding niet hun eerste keuze was (en dus van studiekeuze gewisseld zijn), aangeven dat de ze zodanig door dit gesprek zijn beïnvloed dat ze van studiekeuze gewisseld zijn. Dit geeft namelijk weer dat de leerling, naar eigen zeggen, ten gevolge van het gesprek een andere opleiding is gaan volgen, en derhalve is omgebogen ${ }^{43}$.

In totaal zijn er 504 respondenten die een studiekeuzegesprek hebben gehad en tevens aangeven van studiekeuze gewisseld te zijn. Dit komt neer op IO\% van de totale groep respondenten. De meesten van hen $(44 \%)$ geven aan dat ze zodanig door dat gesprek zijn beïnvloed dat ze van studiekeuze gewisseld zijn (zie tabel 4.7 ).

Met andere woorden, op basis van deze enquête kunnen we vaststellen dat $4.4 \%$ van de jongeren omgebogen is. Het echte aantal jongeren dat door de gesprekken 'omgebogen' is, is naar verwachting zelfs hoger. Van de respondenten die aangeven tussen meerdere studies getwijfeld te hebben (de 'studietwijfelaars') en die een studiekeuzegesprek hebben gehad op de $\mathrm{MBO}$-school, geeft $37 \%$ aan dat ze door het gesprek sterk beïnvloed zijn. Dit komt neer op 6\% van de totale groep respondenten. Van deze groep is weliswaar niet duidelijk vast te stellen dat ze 'omgebogen' zijn, maar terwijl de $4.4 \%$ als een soort minimumgrens gezien kan worden, geeft dit wel een indicatie van een maximumgrens van rond de I0\% (4\% afkomstig van de studiewisselaars en 6\% afkomstig van de studietwijfelaars). Deze twee grenzen komen daarbij dicht in de buurt van de eerder in dit hoofdstuk berekende grenzen op basis van de enquête onder de scholen (minimaal $4 \%$ en maximaal IO\% van de leerlingen die zich aangemeld hebben zijn 'omgebogen').

Er is echter ook een aanzienlijke groep (38\%) die vindt dat het gesprek ze helemaal niet heeft beïnvloed in de studiekeuze. Dit zijn jongeren die weliswaar van studiekeuze gewisseld zijn, maar die die beslissing naar eigen zeggen niet ten gevolge van het gesprek hebben gemaakt.

\section{Tabel 4.7}

Hebben studiekeuze-wisselaars die een studiekeuzegesprek hebben gehad zelf het idee dat ze ten gevolge van het gesprek van studiekeuze zijn gewisseld?

\begin{tabular}{|l|l|}
\hline Niet, wat ik nu doe was ik toch al van plan & 37.9 \\
\hline lk ben een andere opleiding gaan volgen dan ik in eerste instantie van plan was & 43.8 \\
\hline Anders, namelijk & 18.3 \\
\hline
\end{tabular}

Bron: Enquête onder MBO-BOL instroom

43. Nogmaals: dit wil niet per definitie zeggen dat de school actief heeft geprobeerd om de leerling om te buigen, noch dat de leerling nu werkelijk in een opleiding zit met relatief betere arbeidsmarktperspectieven; het is slechts de subjectieve effectiviteit van een studiekeuzegesprek. 


\section{Box 4.1}

Redenen voor het volgen van de huidige MBO-opleiding

Het is niet alleen interessant om te bestuderen of het studiekeuzegesprek de studiekeuze beïnvloed heeft, maar ook wat in het algemeen de studiekeuze heeft beïnvloed. Het is immers aannemelijk dat het studiekeuzegesprek niet de enige factor is die van invloed is op het keuzeproces. Aan de respondenten is daarom gevraagd waarom ze voor de opleiding die ze nu volgen hebben gekozen (meerkeuze). In onderstaande tabel zijn de redenen weergegeven die door ten minste $10 \%$ van de respondent werden genoemd. Hieruit blijkt dat intrinsieke motivatie voor het volgen van een opleiding zeer belangrijk is bij de studiekeuze: veruit de meeste respondenten (72\%) volgen een opleiding omdat dat dat ze het leukst of meest interessant leek. Hoewel dit aandeel wat lager is onder degenen die momenteel een opleiding volgen die niet hun aanvankelijke eerste keuze was, noemt ook onder deze groep iets meer dan de helft (54\%) deze reden voor hun studiekeuze. Ongeveer een derde van de respondenten geeft aan hun huidige opleiding nodig te hebben als voorbereiding op een mogelijke vervolgopleiding, maar de verschillen tussen de totale groep en de groep dat een studiekeuzegesprek heeft gehad en/of van studiekeuze gewisseld is, is marginaal (+/- 3\%punten). De goede kansen op het vinden van werk is voor ongeveer een kwart van de respondenten een reden om voor de huidige opleiding te hebben gekozen. Tot slot geeft zo'n 10\% van de respondenten aan dat ze hun huidige opleiding volgen omdat dat werd geadviseerd door hun ouders/verzorgers. Onder degenen die momenteel een andere opleiding volgen dan ze in eerste instantie van plan waren is dit aandeel wat hoger (zo'n 15\%).

Tabel B4.1

Redenen voor het kiezen van de huidige MBO-opleiding (meerkeuze) (\%)

\begin{tabular}{|c|c|c|c|c|}
\hline & Totaal & Gesprek: Ja & Studiewissel: Ja & $\begin{array}{r}\text { Studiewissel: Ja } \\
\text { \& Omgebogen: }\end{array}$ \\
\hline $\begin{array}{l}\text { Deze opleiding lijkt mij het leukst/het meest } \\
\text { interessant }\end{array}$ & 72 & 71 & 54 & 54 \\
\hline $\begin{array}{l}\text { Deze opleiding heb ik nodig als voorbereiding op een } \\
\text { andere opleiding die ik later wil gaan volgen }\end{array}$ & 33 & 35 & 30 & 36 \\
\hline $\begin{array}{l}\text { De goede kansen op het vinden van werk met deze } \\
\text { opleiding }\end{array}$ & 24 & 23 & 24 & 20 \\
\hline $\begin{array}{l}\text { Mijn ouders/verzorgers adviseerden mij om deze } \\
\text { opleiding te gaan volgen }\end{array}$ & 10 & 10 & 14 & 15 \\
\hline
\end{tabular}

Bron: Enquête onder MBO-BOL instroom

Wanneer we in multivariate regressieanalyses (zie Bijlage 7) wederom o.a. controleren voor de ingeschatte arbeidsmarktperspectieven van de eerste opleidingskeuze, persoonlijke kenmerken, voor kenmerken van de afgeronde VMBO-opleiding, het opleidingsniveau van de vader, en enkele kenmerken van het gesprek, dan komen de volgende factoren naar voren die samenhangen met voor het wel dan niet 'omgebogen' te zijn:

Afgeronde VMBO-opleiding. De leerweg binnen het VMBO dan wel de gevolgde richting binnen het $\mathrm{VMBO}$ is in de regel niet een factor die de kans dat men omgebogen is beïnvloedt. De uitzondering zijn de gediplomeerden van een gecombineerde studierichting in het VMBO. Van hen geeft een significant kleiner deel aan 'omgebogen' te zijn. Echter ook voor deze groep geldt dat een op de drie respondenten- als ze van studiekeuze zijn gewisseld en een gesprek hebben gehad - aangeven dat ze van studiekeuze zijn gewisseld ten gevolge van het gesprek. 
Gesprek (aantal, duur en inhoud ${ }^{44}$ ). Ook hier vinden we weer een negatieve correlatie tussen tijdens het gesprek de toekomstplannen voor de lange termijn te bespreken en de kans dat de studiekeuze-wisselaar aangeeft dat het gesprek van invloed is geweest op de studiekeuze-wissel afneemt. Zowel het aantal gesprekken als de gemiddelde duur laat echter dit keer geen significant verband zien met de kans op ombuiging. ${ }^{45}$

Moment van gesprek. De studiekeuze-wisselaars die relatief laat (in oktober, november of december 20I3) een gesprek over de studiekeuze hebben gehad, hebben een significant kleinere kans om aan te geven dat ze vanwege dat gesprek een andere opleiding zijn gaan doen dan ze in eerste instantie van plan waren. Dit zou ermee te maken kunnen hebben dat als een gesprek pas laat plaatsvindt, er andere factoren kunnen zijn geweest die de studiekeuze beïnvloedden of dat het aantal mogelijke alternatieve keuzes in verband met het al gestarte schooljaar verminderd is.

Problemen in de leefomgeving. Een interessant resultaat zien we als we naar de zelf aangegeven problemen in de leefomgeving kijken. Degenen die aangeven dat ze in het afgelopen jaar veelvuldige contacten met justitie of politie hebben gehad (+56\%-punt) en/of veelvuldig gebruik maakten van internet/gokspellen/computergames (+28\%-punt), hebben een significant grotere kans dan degenen die deze problemen niet melden, om aan te geven dat ze vanwege het gesprek van studiekeuze zijn gewisseld. Dit resultaat laat zien dat de groep jongeren, die vaak als een groep lastige jongeren gezien wordt, door studiekeuze gesprekken op scholen wel beïnvloedbaar is.

\subsection{Ingeschatte arbeidsmarktperspectieven van de eerste en uiteindelijke studiekeuze}

In dit hoofdstuk is al vaker aan de orde gewest in hoeverre de (zelf ingeschatte) arbeidsmarktperspectieven van de eerst studiekeuze van belang zijn bij het eventueel wisselen van studiekeuze. Een van de doelstellingen van het School Ex 2.0 programma is door ombuigingsgesprekken jongeren die zich hebben ingeschreven voor een opleiding met slechte arbeidsmarktperspectieven op de hoogte te brengen van de arbeidsmarktperspectieven om ze zodoende over te halen om wat anders te gaan studeren. In dit slotstuk van hoofdstuk 4 staan we daarom beschrijvend kort stil bij de vraag of jongeren die van studiekeuze gewisseld zijn het idee hebben dat daardoor hun arbeidsmarktperspectieven verbeterd zijn. Hiervoor is aan de jongeren gevraagd om zowel voor de eerste keuze als voor de uiteindelijke keuze een inschatting te maken van hoe moeilijk het zou zijn om na afronding van de opleiding een baan te vinden (gemeten op een 5-punt Likert schaal van I 'heel moeilijk' tot 5 'heel makkelijk en de additionele antwoord categorie 'weet ik

44. Zoals eerder vermeld is het mogelijk dat de opzet (antal gesprekken, duur) of inhoud van het gesprek niet per se exogeen dient te zijn. Aanvullende analyses laten zien dat deze mogelijke endogeniteit echter geen invloed op de uitkomsten van de andere variabelen heeft.

45. Wat het aantal gesprekken betreft, laten de multivariate analyses op een IO\% significantie niveau wel zien dat de kans dat men 'omgebogen' is, met het aantal gesprekken dat men heeft gevoerd toeneemt. 
niet'). Tabel 4.8 laat in eerste instantie zien welk aandeel van de jongeren moeite heeft om een inschatting van de arbeidsmarktperspectieven te geven. In totaal is dat zo'n $9 \%$, waarbij we zien dat het percentage respondenten dat aangeeft dat ze niet weten wat de arbeidsmarktperspectieven van hun eerste dan wel huidige opleidingskeuze is, nauwelijks verschilt tussen degenen die een gesprek hebben gehad dan onder degenen die geen gesprek gehad hebben.

\section{Tabel 4.8}

Percentage respondenten dat aangeeft dat ze niet weten hoe moeilijk het straks zal zijn een baan te vinden met het diploma van de huidige opleiding

\begin{tabular}{|l|r|}
\hline Gesprek over studiekeuze gehad op school? & $8.1 \%$ \\
\hline Nee & $9.0 \%$ \\
\hline Ja & $8.7 \%$ \\
\hline Totaal
\end{tabular}

Bron: Enquête onder MBO-BOL instroom

Het doel van ombuigingsgesprekken is uiteraard niet zo zeer dat jongeren hun studiekeuze veranderen, maar dat als ze van studiekeuze wisselen, ze een opleiding gaan volgen met relatief betere perspectieven dan hun aanvankelijke keuze. In tabel 4.9 is te zien dat bijna de helft van de respondenten die van studiekeuze gewisseld is $(42 \%)$, het idee heeft dat de kansen op het vinden van een baan beter zijn met een diploma van hun huidige opleiding dan met een diploma van hun aanvankelijke eerste studiekeuze:

- $\quad$ I3\% denkt dat ze van 'moeilijke' naar 'makkelijke' kansen op werk zijn gewisseld en daarmee een grote verbetering hebben meegemaakt.

- I8\% denkt dat ze van “moeilijke' naar 'neutrale' kansen op werk zijn gewisseld en daarmee een lichte verbetering hebben meegemaakt.

- $\quad$ I2\% denkt dat ze van 'neutrale' naar 'makkelijke' kansen op werk zijn gewisseld en daarmee een lichte verbetering hebben meegemaakt.

Tabel 4.9

Verandering van de door de studiewisselaars ingeschatte kansen op werk

\begin{tabular}{|l|r|}
\hline moeilijk $\rightarrow$ makkelijk & $\%$ \\
\hline neutraal $\rightarrow$ makkelijk & 12.5 \\
\hline moeilijk $\rightarrow$ neutraal & 11.8 \\
\hline makkelijk $\rightarrow$ neutraal & 17.7 \\
\hline neutraal $\rightarrow$ moeilijk & 7.7 \\
\hline makkelijk $\rightarrow$ moeilijk & 10.0 \\
\hline makkelijk $\rightarrow$ makkelijk & 2.6 \\
\hline neutraal $\rightarrow$ neutraal & 6.2 \\
\hline moeilijk $\rightarrow$ moeilijk & 25.1 \\
\hline Totaal & 6.3 \\
\hline
\end{tabular}

Bron: Enquête onder MBO-BOL instroom 
$38 \%$ van de jongeren die van studiekeuze gewisseld is, denkt dat de arbeidsmarktkansen daardoor vergelijkbaar zijn gebleven. Van hen denkt overigens slechts 6\%-punt dat de arbeidsmarktkansen moeilijk zijn. Tot slot zien we dat 2I\% van mening is dat hun arbeidsmarktperspectieven zelfs verslechterd zijn. Van hen geeft daarbij gelukkig slechts $3 \%$-punt aan naar hun eigen inschatting zij van een opleiding met 'makkelijke' kansen op werk naar 'moeilijke' kansen op werk zijn overgestapt.

\section{Box 4.2}

Studiewissel richting MBO Techniek

In het algemeen geldt dat van de $\mathrm{MBO}-\mathrm{BOL}$ opleidingen de technische studies relatief goede arbeidsmarktperspectieven hebben. MBO Techniek is daarom een interessante sector om naartoe om te buigen. Van de 147 respondenten die momenteel een technische MBO-BOL opleiding volgen, geeft $62 \%$ aan dat ze hun opleidingskeuze op school hebben besproken: onder de totale groep respondenten was dat $66 \%$ (zie tabel B4.2.1). In multivariate analyses zien we dat de kans dat een VMBO-gediplomeerde die momenteel een technische MBO-opleiding volgt aangeeft dat de huidige opleiding niet de eerste keuze was, niet wordt beïnvloed door het al dan niet hebben gehad van een studiekeuzegesprek. De studiekeuze-wissel richting techniek wordt wel beïnvloed door de eigen ingeschatte arbeidsmarktperspectieven van de eerste opleidingskeuze. Degenen die denken dat het (heel) moeilijk zou zijn geweest een baan te vinden met het diploma van hun eerste keuze op zak, hebben een significant grotere kans om naar techniek te zijn gewisseld. Ook degenen die tijdens het gesprek andere mogelijke opleidingen hebben besproken en/of aangeven door het gesprek te zijn beïnvloed, geven significant vaker aan dat hun huidige - technische - opleiding niet hun eerste keuze was. Van de respondenten die momenteel een technische MBO-BOL opleiding volgen, maar hebben aangegeven dat hun huidige opleiding niet hun eerste keuze is, geeft $42 \%$ aan dat ze van studiekeuze zijn gewisseld vanwege het gesprek dat ze hebben gehad op school. Een even grote groep geeft echter aan dat de studiekeuze-wissel richting techniek hun eigen beslissing is geweest.

\section{Tabel B4.2.1}

Hebben degenen die momenteel in een technische MBO-opleiding zitten maar waarvoor hun huidige opleiding niet hun eerste keuze was, zelf het idee dat ze ten gevolge van het studiekeuzegesprek van studiekeuze zijn gewisseld? (\%)

\begin{tabular}{|l|l|}
\hline Niet, wat ik nu doe was ik toch al van plan & 42.0 \\
\hline Ik ben een andere opleiding gaan volgen dan ik in eerste instantie van plan was & 42.0 \\
\hline Anders, namelijk: & 15.9 \\
\hline
\end{tabular}

Ook hier kunnen we bestuderen waarom degenen die momenteel een technische studie doen überhaupt voor deze technische studie gekozen hebben (zie tabel B4.2.2). Intrinsieke motivatie lijkt voor degenen die voor een technische studie hebben gekozen nog wat belangrijker te zijn dan voor de totale groep respondenten: zelfs degenen voor wie de huidige opleiding niet hun eerste keuze was geeft $65 \%$ aan dat deze (technische) opleiding ze het leukst/meest interessant leek. Ook de goede kansen op het vinden van werk worden wat vaker genoemd onder degenen die momenteel een technische MBO-opleiding volgen dan onder de totale groep respondenten. Degenen voor wie de huidige opleiding niet de eerste keuze was, geven iets vaker dan gemiddeld aan dat hun VMBO-school en/of hun ouders ze hebben geadviseerd om deze (technische) studie te gaan volgen. Een technische studie wordt daarentegen relatief wat minder vaak gevolgd ter voorbereiding op vervolgonderwijs. 
Tabel B4.2.2

Waarom hebben degenen die momenteel een technische MBO-opleiding volgen voor hun technische studie gekozen? (\%)

\begin{tabular}{|c|c|c|c|}
\hline & Totaal & Totaal Technici & $\begin{array}{l}\text { Studiewisselaars } \\
\text { richting techniek }\end{array}$ \\
\hline Deze opleiding lijkt mij het leukst/het meest interessant & 72 & 76 & 65 \\
\hline $\begin{array}{l}\text { Deze opleiding heb ik nodig als voorbereiding op een andere opleiding } \\
\text { die ik later wil gaan volgen }\end{array}$ & 33 & 20 & 22 \\
\hline Mijn VMBO-school adviseerde mij om deze opleiding te gaan volgen & 6 & 7 & 10 \\
\hline $\begin{array}{l}\text { Mijn ouders/verzorgers adviseerden mij om deze opleiding te gaan } \\
\text { volgen }\end{array}$ & 10 & 12 & 15 \\
\hline De goede kansen op het vinden van werk met deze opleiding & 24 & 31 & 25 \\
\hline
\end{tabular}

Bron: Enquête onder MBO-BOL instroom

\subsection{Conclusies 'Ombuigingsgesprekken/studiekeuzegesprekken’}

- Studiekeuzegesprekken hebben op grote schaal plaatsgevonden binnen MBO-scholen. Net als bij de exitgesprekken lijken de scholen niet selectief te zijn geweest in wie er een studiekeuzegesprek kreeg.

- Bijna een op de twee VMBO-gediplomeerden die in het MBO-BOL instroomt blijft niet bij zijn eerste en enige studiekeuze. Dit is een duidelijke indicatie dat jongeren vaak twijfelen over hun studiekeuze en daarom in het beginsel ook door studiekeuzegesprekken beïnvloedbaar zijn.

- Jongeren die kennis hebben van slechte arbeidsmarktperspectieven hebben een grotere kans om van studiekeuze te wisselen. Respondenten die denken dat het (heel) moeilijk zou zijn om een baan te vinden met het diploma van hun eerste opleidingskeuze op zak, hebben een significant grotere kans om van studiekeuze te zijn gewisseld dan degenen die denken dat het niet moeilijk maar ook niet makkelijk zou zijn om een baan te vinden met dat diploma.

- $\quad 4.4 \%$ van de respondenten geeft aan door een studiekeuzegesprek te zijn omgebogen. Als we daar de 'studietwijfelaars' die aangeven sterk door een studiekeuzegesprek te zijn beïnvloed bij optellen, komen we op ruim IO\% van de totale groep respondenten dat omgebogen zou kunnen worden.

- $\quad 42 \%$ van de respondenten die van studiekeuze gewisseld zijn (7\% van de totale groep respondenten) denkt dat hun kansen op het vinden van een baan beter zijn met een diploma van hun huidige opleiding dan met een diploma van hun aanvankelijke studiekeuze op zak. 

BIJLAGEN 


\section{Bijlage 1}

Beleidstheorie voor het School-Ex 2.o programma.

In de brief van de ministers van SZW en OCW van maart 2013 wordt de Aanpak Jeugdwerkloosheid nader toegelicht. De doelstelling van de aanpak is daarbij zowel het bestrijden van de actuele jeugdwerkloosheid (en een verdere stijging daarin) evenals het voorkomen van toekomstige jeugdwerkloosheid. Onderstaand overzicht biedt een korte samenvatting van de Aanpak Jeugdwerkloosheid.

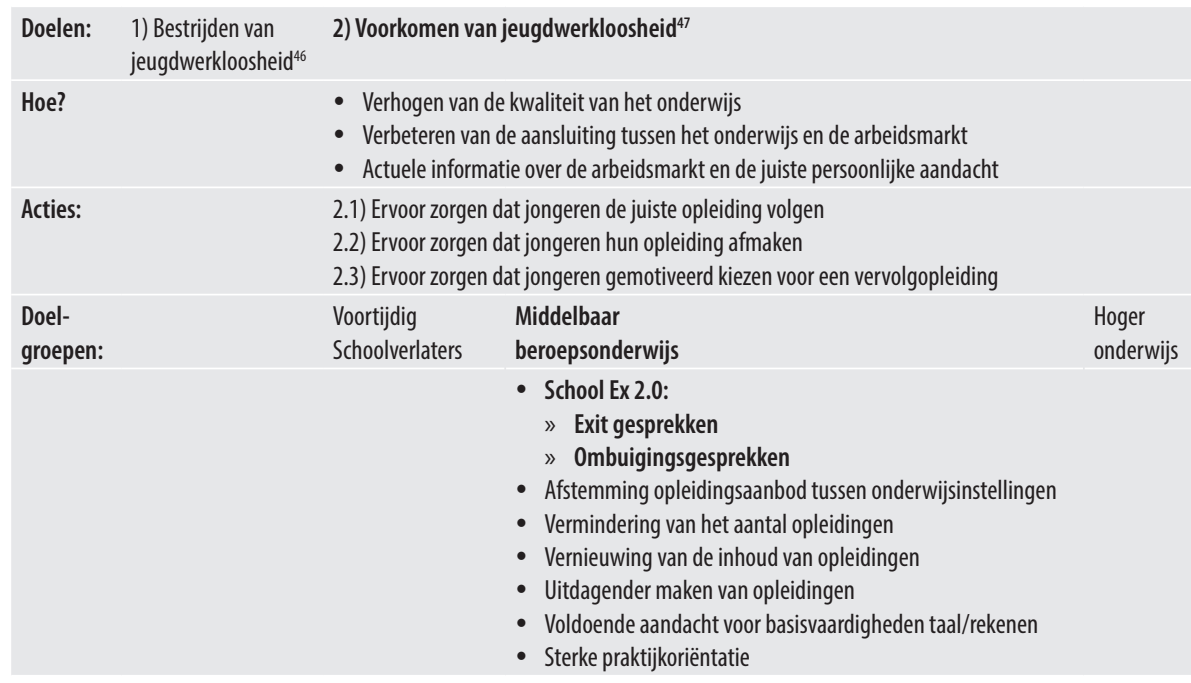

In het kader van de Aanpak Jeugdwerkloosheid staat in 2013 het School Ex 2.0 programma met Exit gesprekken en Ombuigingsgesprekken centraal. Onderstaand overzicht biedt een korte samenvatting van het School Ex 2.0 programma en vermeldt de onderliggende assumpties. Schema I gaat daarna nader in op de opbouw wat de Ombuigingsgesprekken betreft en Schema 2 doet dit voor de Exit gesprekken.

46. Aanpak Jeugdwerkloosheid, brief van de ministers van SZW en OCW aan de Tweede Kamer d.d. 05-032013 (2013-20626), p.3

47. Aanpak Jeugdwerkloosheid, brief van de ministers van SZW en OCW aan de Tweede Kamer d.d. 05-032013 (2013-20626), p.6 

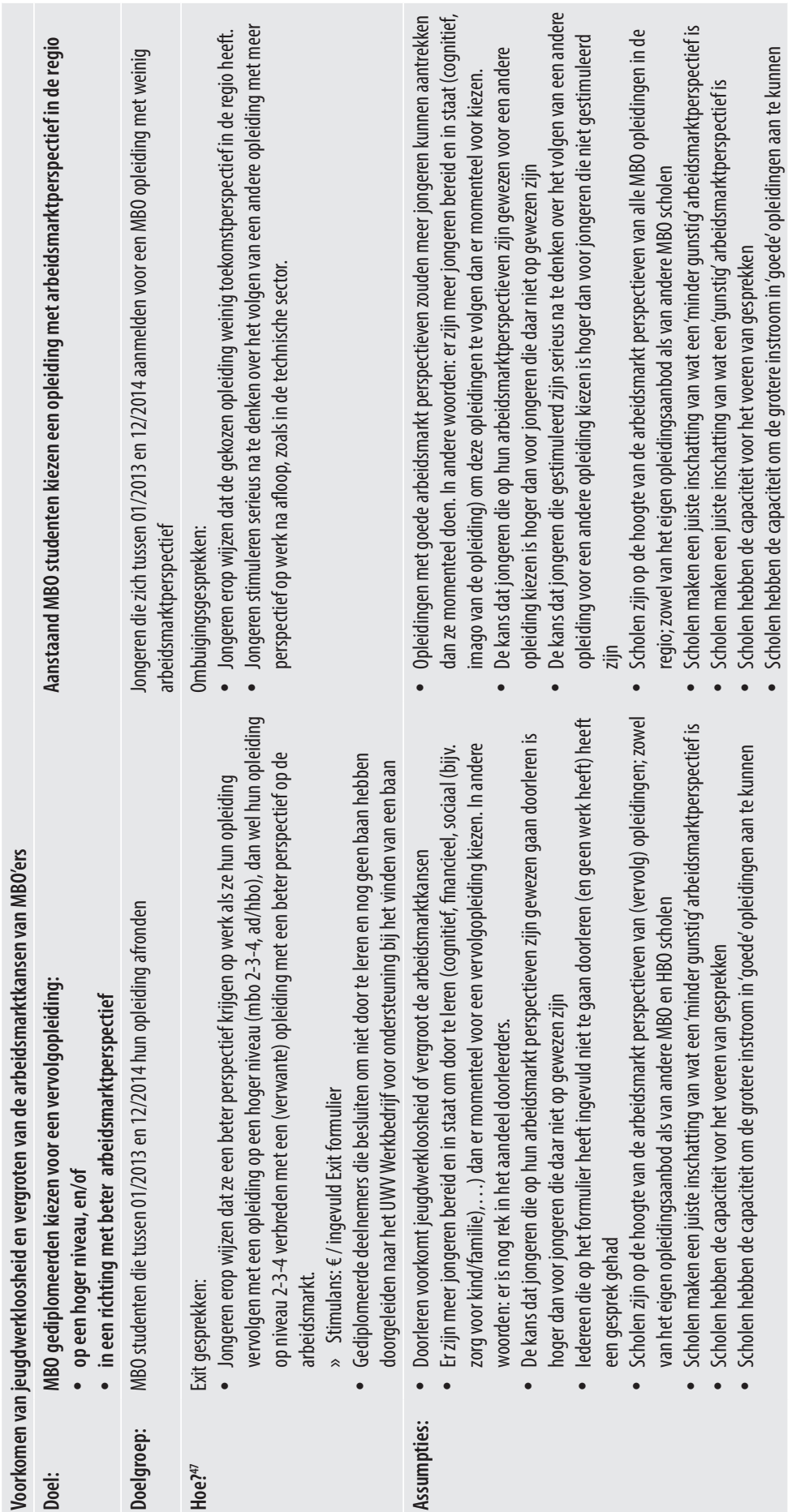


\section{Bijlage 2}

Kans dat een gediplomeerde schoolverlater meldt een exitgesprek te hebben gehad.

\begin{tabular}{|c|c|c|c|}
\hline & B & S.E. & Sig. \\
\hline \multicolumn{4}{|l|}{ Opleidingsniveau } \\
\hline Niveau 1 & 0,056 & 0,040 & 0,164 \\
\hline Niveau 2 & 0,001 & 0,023 & 0,979 \\
\hline Niveau 3 & 0,003 & 0,020 & 0,863 \\
\hline \multicolumn{4}{|l|}{ Niveau 4} \\
\hline \multicolumn{4}{|l|}{ Sector } \\
\hline Landbouw & $-0,038$ & 0,041 & 0,348 \\
\hline Techniek & $-0,064$ & 0,029 & 0,024 \\
\hline Economie & $-0,065$ & 0,025 & 0,009 \\
\hline Gedrag en maatschappij & 0,005 & 0,029 & 0,876 \\
\hline \multicolumn{4}{|l|}{ Zorg en Welzijn } \\
\hline \multicolumn{4}{|l|}{ Leerweg } \\
\hline MBO-BOL & 0,032 & 0,022 & 0,147 \\
\hline \multicolumn{4}{|l|}{ MBO-BBL } \\
\hline Afstudeerdatum april - september & 0,049 & 0,020 & 0,016 \\
\hline \multicolumn{4}{|l|}{ Persoonlijke kenmerken } \\
\hline Man (vrouw = ref.) & 0,000 & 0,020 & 0,995 \\
\hline leeftijd & $-0,014$ & 0,004 & 0,000 \\
\hline \multicolumn{4}{|l|}{ Autochtoon } \\
\hline Westerse allochtoon & 0,009 & 0,035 & 0,802 \\
\hline Niet-Westerse allochtoon & $-0,026$ & 0,027 & 0,332 \\
\hline Afstudeercijfer & 0,022 & 0,012 & 0,067 \\
\hline Zou zelfde opleiding aan zelfde school wederom kiezen & 0,083 & 0,018 & 0,000 \\
\hline Opleidingsniveau vader (1 = laag; 4=hoog) & 0,005 & 0,007 & 0,518 \\
\hline Opleidingsniveau moeder (1 = laag; $4=$ hoog) & $-0,001$ & 0,008 & 0,882 \\
\hline Woont bij 1 ouder & $-0,018$ & 0,041 & 0,667 \\
\hline Woont bij 2 ouders & 0,001 & 0,022 & 0,951 \\
\hline \multicolumn{4}{|l|}{ Woonsituatie anders } \\
\hline Heeft kinderen (nee= ref.) & $-0,047$ & 0,040 & 0,245 \\
\hline \multicolumn{4}{|l|}{ Ervaren problemen in leefgebieden } \\
\hline Financiële problemen/zorgen (bijv. schulden) (niet=ref.) & 0,012 & 0,003 & 0,000 \\
\hline Contacten met justitie of politie (niet=ref.) & 0,012 & 0,009 & 0,165 \\
\hline Drugsgebruik (soft- of harddrugs) (niet=ref.) & $-0,007$ & 0,008 & 0,382 \\
\hline Veelvuldig gebruik van internet/gokspellen/computergames (niet=ref.) & $-0,002$ & 0,005 & 0,732 \\
\hline Problemen met woonsituatie (niet=ref.) & $-0,005$ & 0,005 & 0,324 \\
\hline Problemen met familie/ouders/verzorgers (niet=ref.) & $-0,004$ & 0,005 & 0,337 \\
\hline \multicolumn{4}{|l|}{ Persoonlijke voorkeuren } \\
\hline Een opleiding doen die ik leuk vind <-> een opleiding doen waar ik een baan mee kan vinden & $-0,009$ & 0,008 & 0,232 \\
\hline $\begin{array}{l}\text { Doorleren totdat ik een diploma heb behaald op het voor mij hoogst haalbare niveau <-> gaan } \\
\text { werken zodra dat kan }\end{array}$ & $-0,014$ & 0,007 & 0,043 \\
\hline $\begin{array}{l}\text { Een opleiding doen waarmee ik mijn kansen op het volgen van vervolgopleidingen vergroot }<-> \\
\text { een opleiding doen die mijn kansen op het vinden van werk vergroot }\end{array}$ & 0,006 & 0,008 & 0,421 \\
\hline
\end{tabular}


Na afronding van mijn opleiding zo snel mogelijk kunnen gaan werken $<->$ na afronding van mijn opleiding werk hebben dat aansluit bij mijn gevolgde opleiding

Ik laat mij bij het nemen van beslissingen graag adviseren door anderen $<->\mid \mathrm{k}$ neem beslissingen graag zelfstandig

Constante

0,718

$\mathrm{n}=3240$

Bron: Enquĕte onder $\mathrm{MB} 0$-gediplomeerden 


\section{Bijlage 3}

Kans dat een gediplomeerde schoolverlater is gaan doorleren.

\begin{tabular}{|c|c|c|c|}
\hline & B & S.E. & Sig. \\
\hline \multicolumn{4}{|l|}{ Opleidingsniveau } \\
\hline Niveau 1 & 0,153 & 0,058 & 0,009 \\
\hline Niveau 2 & 0,132 & 0,030 & 0,000 \\
\hline Niveau 3 & 0,051 & 0,026 & 0,050 \\
\hline \multicolumn{4}{|l|}{ Niveau 4} \\
\hline \multicolumn{4}{|l|}{ Sector } \\
\hline Landbouw & $-0,005$ & 0,049 & 0,921 \\
\hline Techniek & 0,120 & 0,034 & 0,000 \\
\hline Economie & 0,111 & 0,030 & 0,000 \\
\hline Gedrag en maatschappij & 0,210 & 0,032 & 0,000 \\
\hline \multicolumn{4}{|l|}{ Zorg en Welzijn } \\
\hline \multicolumn{4}{|l|}{ Leerweg } \\
\hline MBO-BOL & 0,165 & 0,027 & 0,000 \\
\hline \multicolumn{4}{|l|}{ MBO-BBL } \\
\hline Afstudeerdatum april - september & 0,036 & 0,026 & 0,161 \\
\hline \multicolumn{4}{|l|}{ Persoonlijke kenmerken } \\
\hline Man (vrouw = ref.) & 0,016 & 0,026 & 0,534 \\
\hline Leeftijd & $-0,068$ & 0,005 & 0,000 \\
\hline \multicolumn{4}{|l|}{ Autochtoon } \\
\hline Westerse allochtoon & 0,032 & 0,046 & 0,481 \\
\hline Niet-Westerse allochtoon & 0,173 & 0,033 & 0,000 \\
\hline Afstudeercijfer & $-0,014$ & 0,016 & 0,376 \\
\hline Zou zelfde opleiding aan zelfde school wederom kiezen & 0,130 & 0,022 & 0,000 \\
\hline Opleidingsniveau vader (1 = laag; 4=hoog) & 0,001 & 0,009 & 0,900 \\
\hline Opleidingsniveau moeder (1 = laag; $4=$ hoog) & 0,007 & 0,010 & 0,499 \\
\hline Woont bij 1 ouders & $-0,051$ & 0,050 & 0,315 \\
\hline Woont bij 2 ouders & $-0,042$ & 0,028 & 0,127 \\
\hline \multicolumn{4}{|l|}{ Woonsituatie anders } \\
\hline Heeft kinderen (nee= ref.) & $-0,004$ & 0,057 & 0,942 \\
\hline \multicolumn{4}{|l|}{ Ervaren problemen in leefgebieden } \\
\hline Financiële problemen/zorgen (bijv. schulden) (niet=ref.) & 0,004 & 0,004 & 0,334 \\
\hline Contacten met justitie of politie (niet=ref.) & 0,009 & 0,011 & 0,409 \\
\hline Drugsgebruik (soft- of harddrugs) (niet=ref.) & $-0,014$ & 0,010 & 0,164 \\
\hline Veelvuldig gebruik van internet/gokspellen/computergames (niet=ref.) & 0,005 & 0,007 & 0,438 \\
\hline Problemen met woonsituatie (niet=ref.) & $-0,005$ & 0,007 & 0,456 \\
\hline Problemen met familie/ouders/verzorgers (niet=ref.) & 0,006 & 0,006 & 0,309 \\
\hline \multicolumn{4}{|l|}{ Persoonlijke voorkeuren } \\
\hline Een opleiding doen die ik leuk vind <-> een opleiding doen waar ik een baan mee kan vinden & $-0,010$ & 0,010 & 0,320 \\
\hline $\begin{array}{l}\text { Doorleren totdat ik een diploma heb behaald op het voor mij hoogst haalbare niveau <-> gaan } \\
\text { werken zodra dat kan }\end{array}$ & $-0,128$ & 0,009 & 0,000 \\
\hline $\begin{array}{l}\text { Een opleiding doen waarmee ik mijn kansen op het volgen van vervolgopleidingen vergroot <-> een } \\
\text { opleiding doen die mijn kansen op het vinden van werk vergroot }\end{array}$ & $-0,009$ & 0,010 & 0,392 \\
\hline
\end{tabular}


Na afronding van mijn opleiding zo snel mogelijk kunnen gaan werken $<->$ na afronding van mijn opleiding werk hebben dat aansluit bij mijn gevolgde opleiding

Ik laat mij bij het nemen van beslissingen graag adviseren door anderen $<->\mid \mathrm{k}$ neem beslissingen graag zelfstandig

gesprek gehad

Formulier / enquete

$\begin{array}{rrr}-0,068 & 0,029 & 0,019\end{array}$

Geen informatie aan school verstrekt

$\begin{array}{lll}-0,025 & 0,031 \quad 0,427\end{array}$

Constante

0,488

$\mathrm{n}=3240$

Bron: Enquěte onder MBO-gediplomeerden 


\section{Bijlage 4.1}

Kans dat een gediplomeerde schoolverlater aangeeft vanwege het exitgesprek te zijn gaan door studeren.

\begin{tabular}{|c|c|c|c|}
\hline & B & S.E & Sig. \\
\hline \multicolumn{4}{|l|}{ Opleidingsniveau } \\
\hline Niveau 1 & 0,150 & 0,061 & 0,014 \\
\hline Niveau 2 & 0,123 & 0,031 & 0,000 \\
\hline Niveau 3 & 0,044 & 0,025 & 0,085 \\
\hline \multicolumn{4}{|l|}{ Niveau 4} \\
\hline \multicolumn{4}{|l|}{ Sector } \\
\hline Landbouw & $-0,021$ & 0,044 & 0,637 \\
\hline Techniek & 0,013 & 0,033 & 0,704 \\
\hline Economie & 0,038 & 0,029 & 0,187 \\
\hline Gedrag en maatschappij & 0,037 & 0,034 & 0,286 \\
\hline \multicolumn{4}{|l|}{ Zorg en Welzijn } \\
\hline \multicolumn{4}{|l|}{ Leerweg } \\
\hline MBO-BOL & $-0,004$ & 0,026 & 0,890 \\
\hline \multicolumn{4}{|l|}{ MBO-BBL } \\
\hline Afstudeerdatum april - september & 0,042 & 0,023 & 0,065 \\
\hline \multicolumn{4}{|l|}{ Persoonlijke kenmerken } \\
\hline Man (vrouw = ref.) & $-0,042$ & 0,023 & 0,073 \\
\hline Leeftijd & 0,007 & 0,004 & 0,121 \\
\hline \multicolumn{4}{|l|}{ Autochtoon } \\
\hline Westerse allochtoon & 0,032 & 0,043 & 0,458 \\
\hline Niet-Westerse allochtoon & 0,029 & 0,031 & 0,358 \\
\hline Afstudeercijfer & $-0,010$ & 0,015 & 0,498 \\
\hline Zou zelfde opleiding aan zelfde school wederom kiezen & $-0,080$ & 0,022 & 0,000 \\
\hline Opleidingsniveau vader (1 = laag; 4=hoog) & $-0,005$ & 0,009 & 0,534 \\
\hline Opleidingsniveau moeder (1 = laag; $4=$ hoog) & $-0,011$ & 0,009 & 0,239 \\
\hline Woont bij 1 ouder & $-0,049$ & 0,042 & 0,244 \\
\hline Woont bij 2 ouders & 0,013 & 0,025 & 0,616 \\
\hline \multicolumn{4}{|l|}{ Woonsituatie anders } \\
\hline Heeft kinderen (nee= ref.) & $-0,013$ & 0,048 & 0,793 \\
\hline \multicolumn{4}{|l|}{ Ervaren problemen in leefgebieden } \\
\hline Financiële problemen/zorgen (bijv. schulden) (niet=ref.) & 0,005 & 0,004 & 0,147 \\
\hline Contacten met justitie of politie (niet=ref.) & $-0,009$ & 0,009 & 0,332 \\
\hline Drugsgebruik (soft- of harddrugs) (niet=ref.) & 0,002 & 0,008 & 0,785 \\
\hline Veelvuldig gebruik van internet/gokspellen/computergames (niet=ref.) & 0,000 & 0,006 & 0,962 \\
\hline Problemen met woonsituatie (niet=ref.) & 0,007 & 0,006 & 0,236 \\
\hline Problemen met familie/ouders/verzorgers (niet=ref.) & 0,002 & 0,005 & 0,715 \\
\hline \multicolumn{4}{|l|}{ Persoonlijke voorkeuren } \\
\hline $\begin{array}{l}\text { Een opleiding doen die ik leuk vind <-> een opleiding doen waar ik een baan mee kan } \\
\text { vinden }\end{array}$ & 0,010 & 0,009 & 0,249 \\
\hline $\begin{array}{l}\text { Doorleren totdat ik een diploma heb behaald op het voor mij hoogst haalbare niveau }<-> \\
\text { gaan werken zodra dat kan }\end{array}$ & $-0,015$ & 0,008 & 0,080 \\
\hline
\end{tabular}




\begin{tabular}{|c|c|c|c|}
\hline & B & S.E & Sig \\
\hline $\begin{array}{l}\text { Een opleiding doen waarmee ik mijn kansen op het volgen van vervolgopleidingen vergroot } \\
<->\text { een opleiding doen die mijn kansen op het vinden van werk vergroot }\end{array}$ & $-0,002$ & 0,009 & 0,813 \\
\hline $\begin{array}{l}\text { Na afronding van mijn opleiding zo snel mogelijk kunnen gaan werken }<->\text { na afronding } \\
\text { van mijn opleiding werk hebben dat aansluit bij mijn gevolgde opleiding }\end{array}$ & 0,015 & 0,007 & 0,041 \\
\hline $\begin{array}{l}\text { Ik laat mij bij het nemen van beslissingen graag adviseren door anderen }<->\text { Ik neem } \\
\text { beslissingen graag zelfstandig }\end{array}$ & $-0,026$ & 0,008 & 0,002 \\
\hline \multicolumn{4}{|l|}{ Kenmerken van het exitgesprek } \\
\hline Inhoud gesprek: lange termijn & $-0,055$ & 0,022 & 0,012 \\
\hline Inhoud gesprek: arbeidsmarkt & 0,032 & 0,023 & 0,177 \\
\hline Inhoud gesprek: vervolgopleidingen & 0,044 & 0,020 & 0,026 \\
\hline Inhoud gesprek: capaciteiten & 0,038 & 0,020 & 0,062 \\
\hline Gesprek met docent & 0,016 & 0,022 & 0,457 \\
\hline Gesprek met mentor & $-0,020$ & 0,023 & 0,384 \\
\hline Gesprek met SLB-er & $-0,014$ & 0,024 & 0,540 \\
\hline Gesprek met iemand anders & 0,058 & 0,048 & 0,226 \\
\hline 1 tot maximaal 2 gesprekken & $-0,070$ & 0,026 & 0,007 \\
\hline \multicolumn{4}{|l|}{3 gesprekken } \\
\hline 4 of meer gesprekken & 0,037 & 0,029 & 0,207 \\
\hline Duur gesprek: kort & $-0,026$ & 0,021 & 0,214 \\
\hline \multicolumn{4}{|l|}{ Duur gesprek: gemiddeld } \\
\hline Duur gesprek: lang & 0,038 & 0,036 & 0,296 \\
\hline Constante & 0,254 & & \\
\hline
\end{tabular}

$\mathrm{n}=2249$

Bron: Enquěte onder MBO-gediplomeerden 


\section{Bijlage 4.2}

Kans dat een gediplomeerde schoolverlater aangeeft sterk door het exitgesprek te zijn beïnvloed.

\begin{tabular}{|c|c|c|c|}
\hline & B & S.E & Sig. \\
\hline \multicolumn{4}{|l|}{ Opleidingsniveau } \\
\hline Niveau 1 & 0,254 & 0,063 & 0,000 \\
\hline Niveau 2 & 0,212 & 0,032 & 0,000 \\
\hline Niveau 3 & 0,081 & 0,025 & 0,001 \\
\hline \multicolumn{4}{|l|}{ Niveau 4} \\
\hline \multicolumn{4}{|l|}{ Sector } \\
\hline Landbouw & $-0,026$ & 0,037 & 0,483 \\
\hline Techniek & 0,025 & 0,030 & 0,399 \\
\hline Economie & 0,027 & 0,025 & 0,287 \\
\hline Gedrag en maatschappij & $-0,003$ & 0,029 & 0,926 \\
\hline \multicolumn{4}{|l|}{ Zorg en Welzijn } \\
\hline \multicolumn{4}{|l|}{ Leerweg } \\
\hline MBO-BOL & 0,003 & 0,022 & 0,899 \\
\hline \multicolumn{4}{|l|}{ MBO-BBL } \\
\hline Afstudeerdatum april - september & 0,048 & 0,019 & 0,011 \\
\hline \multicolumn{4}{|l|}{ Persoonlijke kenmerken } \\
\hline Man (vrouw = ref.) & $-0,026$ & 0,020 & 0,210 \\
\hline leeftijd & 0,005 & 0,004 & 0,177 \\
\hline \multicolumn{4}{|l|}{ Autochtoon } \\
\hline Westerse allochtoon & $-0,045$ & 0,031 & 0,152 \\
\hline Niet-Westerse allochtoon & 0,142 & 0,033 & 0,000 \\
\hline Afstudeerciifer & 0,005 & 0,012 & 0,700 \\
\hline Zou zelfde opleiding aan zelfde school wederom kiezen & 0,063 & 0,017 & 0,000 \\
\hline Opleidingsniveau vader (1 = laag; 4=hoog) & $-0,006$ & 0,007 & 0,426 \\
\hline Opleidingsniveau moeder (1 = laag; 4= hoog) & 0,001 & 0,008 & 0,914 \\
\hline Woont bij 1 ouder & $-0,024$ & 0,038 & 0,539 \\
\hline Woont bij 2 ouders & 0,026 & 0,022 & 0,234 \\
\hline \multicolumn{4}{|l|}{ Woonsituatie anders } \\
\hline Heeft kinderen (nee= ref.) & $-0,016$ & 0,040 & 0,686 \\
\hline \multicolumn{4}{|l|}{ Ervaren problemen in leefgebieden } \\
\hline Financiële problemen/zorgen (bijv. schulden) (niet=ref.) & $-0,002$ & 0,003 & 0,559 \\
\hline Contacten met justitie of politie (niet=ref.) & 0,004 & 0,007 & 0,584 \\
\hline Drugsgebruik (soft- of harddrugs) (niet=ref.) & $-0,004$ & 0,007 & 0,582 \\
\hline Veelvuldig gebruik van internet/gokspellen/computergames (niet=ref.) & 0,007 & 0,005 & 0,165 \\
\hline Problemen met woonsituatie (niet=ref.) & 0,005 & 0,005 & 0,333 \\
\hline Problemen met familie/ouders/verzorgers (niet=ref.) & $-0,004$ & 0,005 & 0,384 \\
\hline \multicolumn{4}{|l|}{ Persoonlijke voorkeuren } \\
\hline $\begin{array}{l}\text { Een opleiding doen die ik leuk vind <-> een opleiding doen waar ik een baan mee kan } \\
\text { vinden }\end{array}$ & 0,011 & 0,008 & 0,140 \\
\hline $\begin{array}{l}\text { Doorleren totdat ik een diploma heb behaald op het voor mij hoogst haalbare niveau } \\
<->\text { gaan werken zodra dat kan }\end{array}$ & $-0,015$ & 0,007 & 0,033 \\
\hline $\begin{array}{l}\text { Een opleiding doen waarmee ik mijn kansen op het volgen van vervolgopleidingen } \\
\text { vergroot <-> een opleiding doen die mijn kansen op het vinden van werk vergroot }\end{array}$ & 0,003 & 0,008 & 0,685 \\
\hline
\end{tabular}




\begin{tabular}{|c|c|c|c|}
\hline & B & S.E & Sig. \\
\hline $\begin{array}{l}\mathrm{Na} \text { afronding van mijn opleiding zo snel mogelijk kunnen gaan werken }<->\text { na } \\
\text { afronding van mijn opleiding werk hebben dat aansluit bij mijn gevolgde opleiding }\end{array}$ & 0,004 & 0,006 & 0,499 \\
\hline $\begin{array}{l}\text { Ik laat mij bij het nemen van beslissingen graag adviseren door anderen }<->\text { Ik neem } \\
\text { beslissingen graag zelfstandig }\end{array}$ & $-0,025$ & 0,007 & 0,001 \\
\hline \multicolumn{4}{|l|}{ Kenmerken van het exitgesprek } \\
\hline Inhoud gesprek: lange termijn & $-0,010$ & 0,019 & 0,579 \\
\hline Inhoud gesprek: arbeidsmarkt & 0,032 & 0,020 & 0,111 \\
\hline Inhoud gesprek: vervolgopleidingen & 0,014 & 0,017 & 0,425 \\
\hline Inhoud gesprek: capaciteiten & 0,042 & 0,018 & 0,018 \\
\hline Gesprek met docent & $-0,021$ & 0,018 & 0,241 \\
\hline Gesprek met mentor & 0,012 & 0,020 & 0,551 \\
\hline Gesprek met SLB-er & 0,002 & 0,021 & 0,908 \\
\hline Gesprek met iemand anders & 0,006 & 0,038 & 0,866 \\
\hline 1 tot maximaal 2 gesprekken & $-0,060$ & 0,022 & 0,007 \\
\hline \multicolumn{4}{|l|}{3 gesprekken } \\
\hline 4 of meer gesprekken & 0,023 & 0,024 & 0,352 \\
\hline Duur gesprek: kort & $-0,042$ & 0,018 & 0,020 \\
\hline \multicolumn{4}{|l|}{ Duur gesprek: gemiddeld } \\
\hline Duur gesprek: lang & 0,091 & 0,035 & 0,009 \\
\hline Constante & 0,177 & & \\
\hline
\end{tabular}

$\mathrm{n}=2249$

Bron: Enquĕte onder MB0-gediplomeerden 


\begin{tabular}{|c|c|c|c|c|c|c|}
\hline & 商善旁 & జ & 兽 & 粱 & 器 & 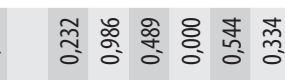 \\
\hline & : : : & 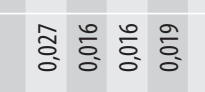 & 言 & 产 & \%: & 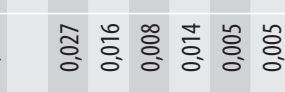 \\
\hline & 쭝 : & 농 훙 : & 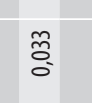 & gి & 亏영 & 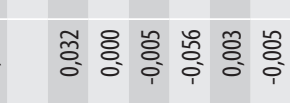 \\
\hline & 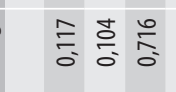 & 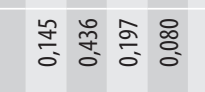 & 幾 & 8 & 亏영 & : \\
\hline & 윰옹 & 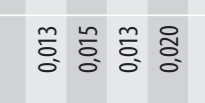 & $\vdots$ & $\stackrel{8}{8}$ & 亏영 & 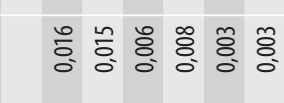 \\
\hline & & 高 & $\stackrel{0}{\circ}$ & $\stackrel{ \pm}{ \pm}$ & 譬 & 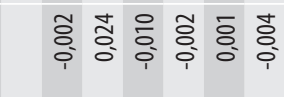 \\
\hline & & 参高 & 产 & $\%$ & $\frac{\tilde{\alpha}}{\sigma} \mathrm{g}$ & 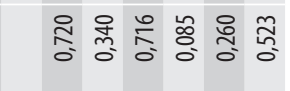 \\
\hline & 善 & 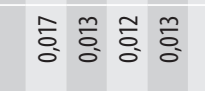 & : & $\stackrel{\circ}{\circ}$ & 气 : & 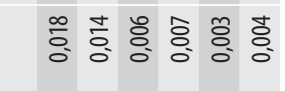 \\
\hline & & & : & $\vdots$ & & \\
\hline
\end{tabular}

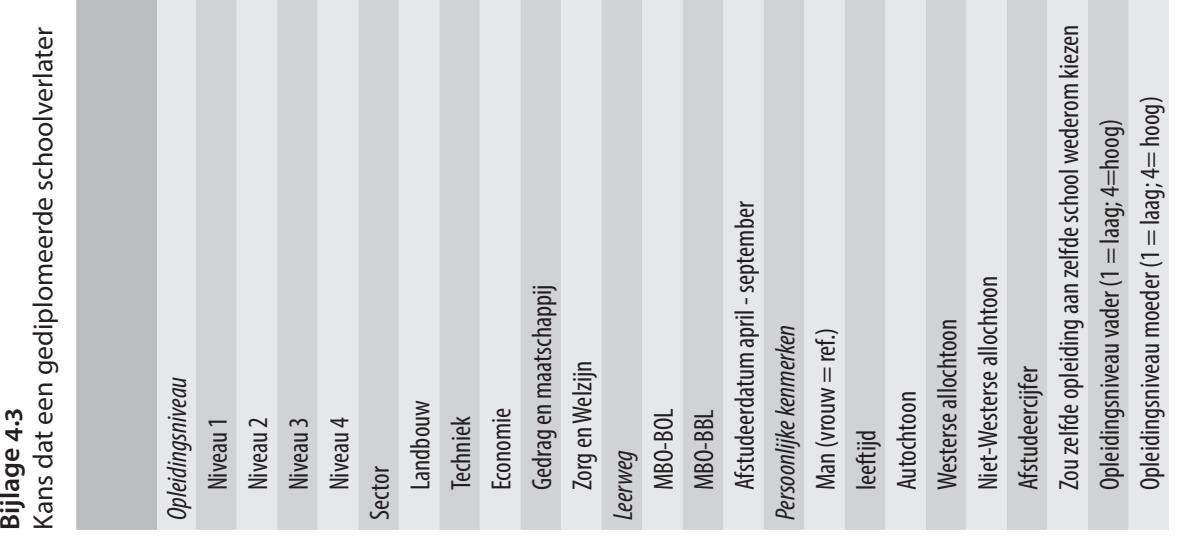




\begin{tabular}{|c|c|c|c|c|c|c|c|c|}
\hline 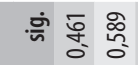 & \% & 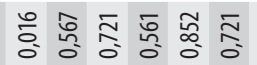 & 变 & 这 & Бू & 兽 & $\frac{\infty}{\infty}$ & 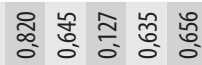 \\
\hline 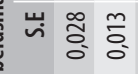 & $\overbrace{0}^{n}$ & 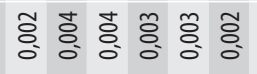 & 管 & 总 & 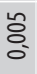 & 总 & : & E. \\
\hline$\infty$ & :̊n: & 홍 & 气̊ & 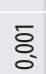 & 5 & 荢 & $0_{0}^{\circ}$ & 范 \\
\hline 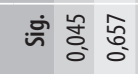 & தू & 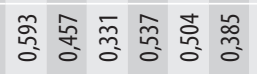 & E. & $\stackrel{\circ}{\circ}$ & 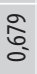 & : & $\begin{array}{l} \pm \\
\text { à } \\
0\end{array}$ & 영 융 응 : \\
\hline 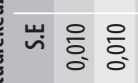 & :̊․ & క్రㅇㅇㅇㅇ : & \%: & 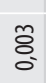 & 8 & $\overbrace{0}^{0}$ & \%: & 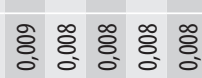 \\
\hline 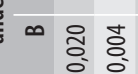 & : & Бㅇㅇㅇㅇㅇㅇ : & & & & & & \\
\hline
\end{tabular}

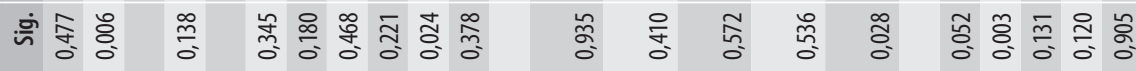

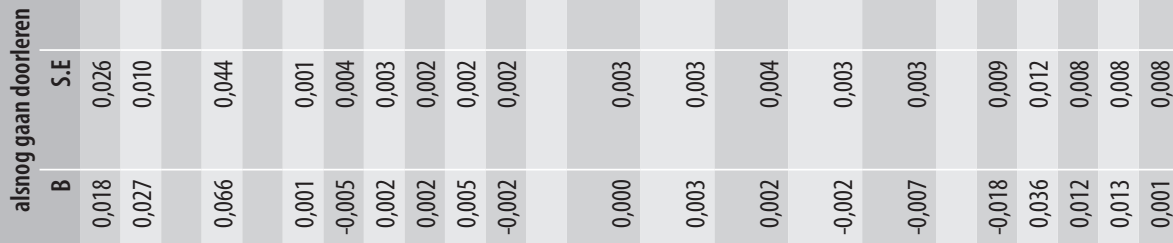

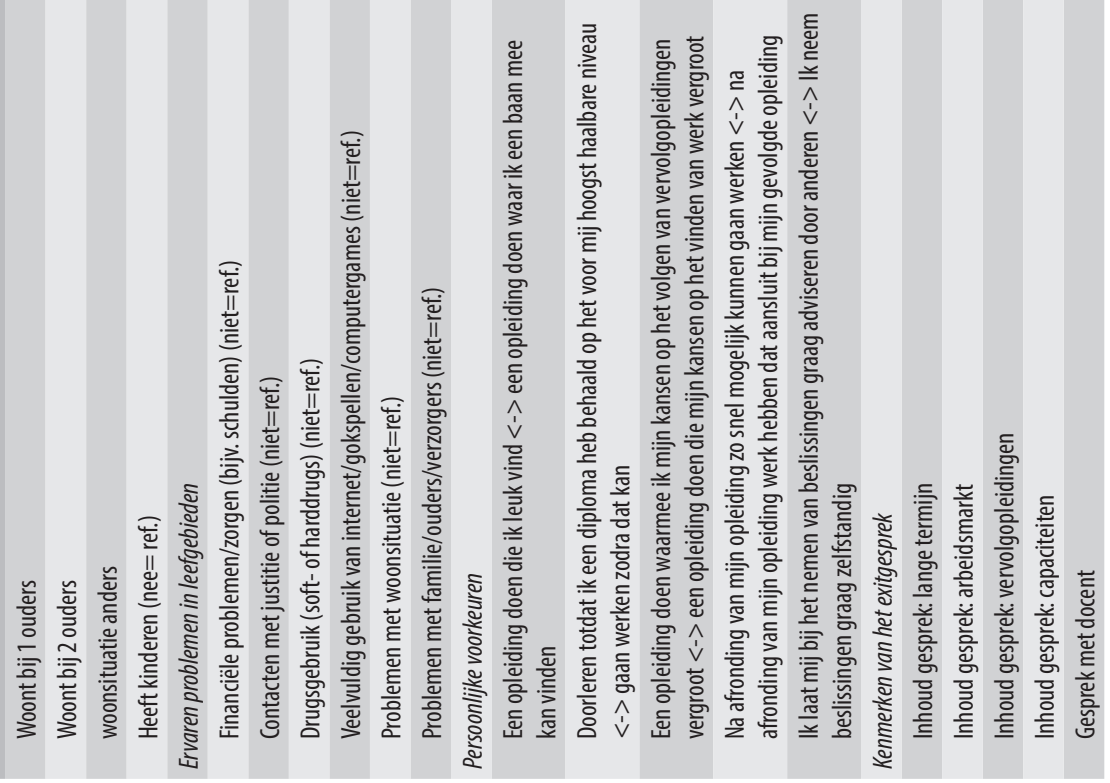




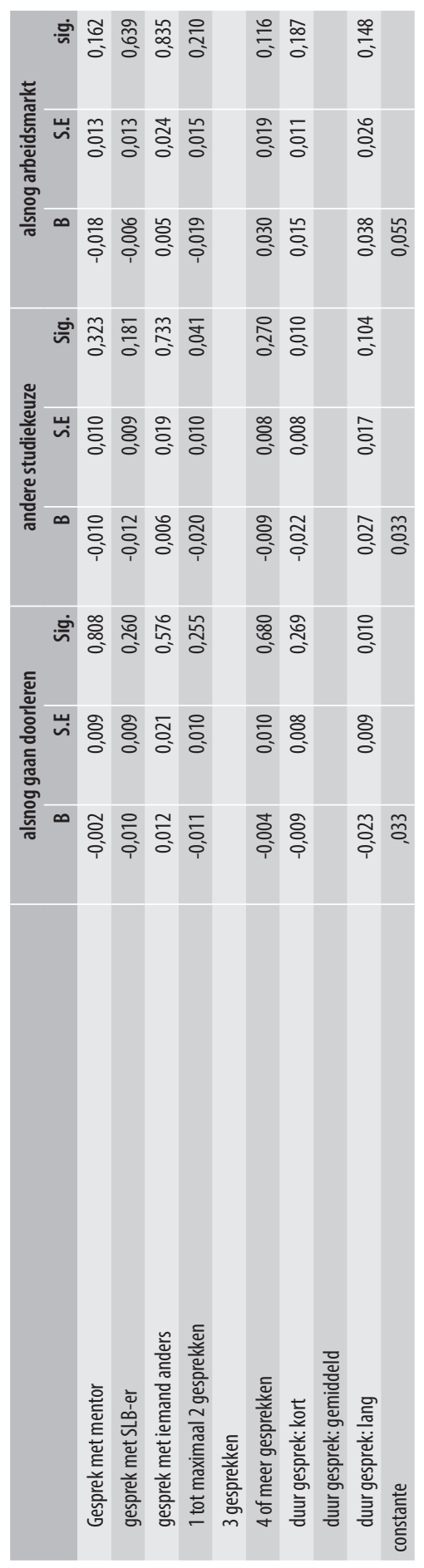




\section{Bijlage 5}

Kans dat een VMBO-uitstromer in het MBO-BOL aangeeft een studiekeuzegesprek te hebben gehad op de MBO-school.

\begin{tabular}{|c|c|c|c|}
\hline & B & S.E. & Sig. \\
\hline \multicolumn{4}{|l|}{ Sector VMBO } \\
\hline Economie & 0,075 & 0,030 & 0,013 \\
\hline Gecombineerde richtingen & 0,060 & 0,033 & 0,070 \\
\hline Landbouw & 0,003 & 0,037 & 0,944 \\
\hline Techniek & ref. & & \\
\hline Zorg\&Welzijn & 0,084 & 0,029 & 0,004 \\
\hline \multicolumn{4}{|l|}{ Leerweg VMBO } \\
\hline BL & $-0,012$ & 0,033 & 0,709 \\
\hline $\mathrm{KL}$ & $-0,036$ & 0,029 & 0,218 \\
\hline GL & $-0,047$ & 0,037 & 0,204 \\
\hline TL & ref. & & \\
\hline \multicolumn{4}{|l|}{ Eindcijfer VMBO } \\
\hline $5,5 \mathrm{t} / \mathrm{m} 6,9$ & $-0,019$ & 0,015 & 0,197 \\
\hline $7,0 \mathrm{t} / \mathrm{m} 8,4$ & ref. & & \\
\hline $8,5 \mathrm{t} / \mathrm{m} 10$ & 0,015 & 0,101 & 0,880 \\
\hline \multicolumn{4}{|l|}{ Persoonlijke kenmerken } \\
\hline Man (vrouw=ref.) & 0,013 & 0,016 & 0,430 \\
\hline Leeftijd & 0,001 & 0,011 & 0,931 \\
\hline Autochtoon & ref. & & \\
\hline Westerse allochtoon & $-0,011$ & 0,035 & 0,753 \\
\hline Niet-Westerse allochtoon & $-0,072$ & 0,025 & 0,004 \\
\hline Opleidingsniveau vader: basisonderwijs & 0,024 & 0,016 & 0,136 \\
\hline Opleidingsniveau vader: voortgezet onderwiis of lager beroepsonderwijs & ref. & & \\
\hline Opleidingsniveau vader: hoger onderwijs & 0,022 & 0,018 & 0,214 \\
\hline \multicolumn{4}{|l|}{ Regio woonachtig } \\
\hline Drenthe & 0,045 & 0,037 & 0,231 \\
\hline Flevoland & $-0,123$ & 0,051 & 0,017 \\
\hline Friesland & 0,084 & 0,030 & 0,006 \\
\hline Gelderland & 0,032 & 0,024 & 0,189 \\
\hline Groningen & 0,038 & 0,039 & 0,329 \\
\hline Limburg & $-0,017$ & 0,032 & 0,585 \\
\hline Noord-Brabant & 0,022 & 0,024 & 0,349 \\
\hline Noord-Holland & $-0,024$ & 0,027 & 0,362 \\
\hline Overijssel & 0,020 & 0,029 & 0,484 \\
\hline Utrecht & 0,046 & 0,032 & 0,149 \\
\hline Zeeland & 0,043 & 0,046 & 0,353 \\
\hline \multicolumn{4}{|l|}{ Zuid-Holland (ref.) } \\
\hline \multicolumn{4}{|l|}{ Ervaren problemen in leefgebieden } \\
\hline Financiële problemen/zorgen (bijv. schulden) (niet=ref.) & $-0,067$ & 0,035 & 0,059 \\
\hline Contacten met justitie of politie (niet=ref.) & 0,088 & 0,060 & 0,146 \\
\hline Drugsgebruik (soft- of harddrugs) (niet=ref.) & 0,004 & 0,065 & 0,947 \\
\hline Veelvuldig gebruik van internet/gokspellen/computergames (niet=ref.) & $-0,053$ & 0,034 & 0,117 \\
\hline
\end{tabular}




\begin{tabular}{|c|c|c|c|}
\hline & B & S.E. & Sig. \\
\hline Problemen met woonsituatie (niet=ref.) & 0,001 & 0,045 & 0,978 \\
\hline Problemen met familie/ouders/verzorgers (niet=ref.) & 0,036 & 0,038 & 0,347 \\
\hline \multicolumn{4}{|l|}{ Persoonlijke voorkeuren } \\
\hline Een opleiding doen die ik leuk vind <-> een opleiding doen waar ik een baan mee kan vinden & 0,009 & 0,007 & 0,214 \\
\hline $\begin{array}{l}\text { Doorleren totdat ik een diploma heb behaald op het voor mij hoogst haalbare niveau <-> gaan } \\
\text { werken zodra dat kan }\end{array}$ & 0,005 & 0,007 & 0,509 \\
\hline $\begin{array}{l}\text { Een opleiding doen waarmee ik mijn kansen op het volgen van vervolgopleidingen vergroot <-> } \\
\text { een opleiding doen die mijn kansen op het vinden van werk vergroot }\end{array}$ & $-0,014$ & 0,007 & 0,055 \\
\hline $\begin{array}{l}\text { Na afronding van mijn opleiding zo snel mogelijk kunnen gaan werken <-> na afronding van } \\
\text { mijn opleiding werk hebben dat aansluit bij mijn gevolgde opleiding }\end{array}$ & $-0,003$ & 0,006 & 0,608 \\
\hline $\begin{array}{l}\text { Ik laat mij bij het nemen van beslissingen graag adviseren door anderen }<->\text { Ik neem } \\
\text { beslissingen graag zelfstandig }\end{array}$ & $-0,007$ & 0,006 & 0,255 \\
\hline \multicolumn{4}{|l|}{ Door respondent waargenomen kenmerken van de school } \\
\hline $\begin{array}{l}\text { School heeft (behalve gesprekken) activiteiten ondernomen om te helpen bij het maken van } \\
\text { studiekeuzes (niet=ref.) }\end{array}$ & 0,082 & 0,019 & 0,000 \\
\hline Constante & 0,666 & & \\
\hline
\end{tabular}

$\mathrm{n}=4545$

Bron: Enquĕte onder MB0-gediplomeerden 


\section{Bijlage 6}

Kans dat een VMBO-instromer in het MBO-BOL aangeeft van studiekeuze te zijn gewisseld.

\begin{tabular}{|c|c|c|c|}
\hline & B & S.E. & Sig. \\
\hline \multicolumn{4}{|l|}{ Ingeschatte arbeidsmarktkansen van de eerst studiekeuze } \\
\hline (heel) Moeilijk & 0,186 & 0,023 & 0,000 \\
\hline Niet moeilijk maar ook niet makkelijk & ref. & & \\
\hline (heel) Makkelijk & $-0,021$ & 0,019 & 0,263 \\
\hline Studiekeuzegesprek gehad (niet=ref.) & 0,045 & 0,038 & 0,235 \\
\hline \multicolumn{4}{|l|}{ Kenmerken van studiekeuzegesprekken } \\
\hline Gesprek met docent & $-0,003$ & 0,022 & 0,888 \\
\hline Gesprek met mentor & $-0,026$ & 0,022 & 0,237 \\
\hline Gesprek met SLB-er & 0,017 & 0,024 & 0,489 \\
\hline Gesprek met iemand anders & 0,031 & 0,036 & 0,388 \\
\hline 1 gesprek & $-0,036$ & 0,019 & 0,064 \\
\hline \multicolumn{4}{|l|}{2 tot 3 gesprekken } \\
\hline 4 of meer gesprekken & 0,050 & 0,034 & 0,143 \\
\hline Gesprek in jan-dec 2012 & $-0,058$ & 0,026 & 0,027 \\
\hline Gesprek in jan/feb/mrt 2013 & $-0,034$ & 0,025 & 0,167 \\
\hline Gesprek in april/mei/juni 2013 & ref. & & \\
\hline Gesprek in jul/aug/sep 2013 & 0,084 & 0,034 & 0,012 \\
\hline Gesprek in okt/nov/dec 2013 & 0,072 & 0,034 & 0,031 \\
\hline Duur gesprek: $10 \mathrm{~min}$. & $-0,047$ & 0,019 & 0,015 \\
\hline Duur gesprek: 10-30 min. & ref. & & \\
\hline Duur gesprek: $30 \mathrm{~min}$. of meer & 0,089 & 0,034 & 0,009 \\
\hline Inhoud gesprek: lange termijn & $-0,086$ & 0,018 & 0,000 \\
\hline Inhoud gesprek: arbeidsmarkt & 0,007 & 0,023 & 0,766 \\
\hline Inhoud gesprek: capaciteiten & 0,004 & 0,019 & 0,841 \\
\hline Inhoud gesprek: opleiding waarvoor was aangemeld & $-0,064$ & 0,020 & 0,002 \\
\hline Inhoud gesprek: andere opleidingen & 0,278 & 0,034 & 0,000 \\
\hline Inhoud gesprek: anders & 0,019 & 0,037 & 0,607 \\
\hline Oordeel: het gesprek was (heel) nuttig & $-0,062$ & 0,020 & 0,002 \\
\hline Oordeel: (volledig) beïnvloed door gesprek & 0,064 & 0,025 & 0,010 \\
\hline \multicolumn{4}{|l|}{ Sector VMBO } \\
\hline Economie & 0,018 & 0,035 & 0,618 \\
\hline Gecombineerde richtingen & 0,043 & 0,040 & 0,284 \\
\hline Landbouw & $-0,040$ & 0,033 & 0,233 \\
\hline Techniek & ref. & & \\
\hline Zorg\&Welzijn & $-0,045$ & 0,028 & 0,111 \\
\hline \multicolumn{4}{|l|}{ Leerweg VMBO } \\
\hline$B L$ & 0,057 & 0,037 & 0,128 \\
\hline $\mathrm{KL}$ & 0,022 & 0,031 & 0,469 \\
\hline $\mathrm{GL}$ & $-0,005$ & 0,037 & 0,893 \\
\hline TL & ref. & & \\
\hline \multicolumn{4}{|l|}{ Eindcijfer VMBO } \\
\hline $5,5 \mathrm{t} / \mathrm{m} 6,9$ & 0,018 & 0,015 & 0,247 \\
\hline $7,0 \mathrm{t} / \mathrm{m} 8,4$ & ref. & & \\
\hline
\end{tabular}




\begin{tabular}{|c|c|c|c|}
\hline & B & S.E. & Sig. \\
\hline $8,5 \mathrm{t} / \mathrm{m} 10$ & $-0,066$ & 0,074 & 0,376 \\
\hline \multicolumn{4}{|l|}{ Persoonlijke kenmerken } \\
\hline Man (vrouw=ref.) & $-0,026$ & 0,016 & 0,115 \\
\hline Leeftijd & $-0,010$ & 0,011 & 0,385 \\
\hline Autochtoon & ref. & & \\
\hline Westerse allochtoon & 0,074 & 0,041 & 0,073 \\
\hline Niet-Westerse allochtoon & 0,043 & 0,026 & 0,099 \\
\hline Opleidingsniveau vader: basisonderwijs & 0,026 & 0,017 & 0,130 \\
\hline Opleidingsniveau vader: voortgezet onderwijs of lager beroepsonderwijs & ref. & & \\
\hline Opleidingsniveau vader: hoger onderwijs & 0,028 & 0,020 & 0,156 \\
\hline \multicolumn{4}{|l|}{ Regio woonachtig } \\
\hline Drenthe & 0,057 & 0,047 & 0,223 \\
\hline Flevoland & 0,018 & 0,050 & 0,725 \\
\hline Friesland & $-0,003$ & 0,036 & 0,935 \\
\hline Gelderland & 0,026 & 0,027 & 0,338 \\
\hline Groningen & 0,016 & 0,046 & 0,735 \\
\hline Limburg & 0,014 & 0,035 & 0,680 \\
\hline Noord-Brabant & $-0,013$ & 0,024 & 0,597 \\
\hline Noord-Holland & $-0,028$ & 0,024 & 0,236 \\
\hline Overijssel & $-0,018$ & 0,030 & 0,538 \\
\hline Utrecht & $-0,008$ & 0,035 & 0,830 \\
\hline Zeeland & 0,053 & 0,054 & 0,324 \\
\hline \multicolumn{4}{|l|}{ Zuid-Holland (ref.) } \\
\hline \multicolumn{4}{|l|}{ Ervaren problemen in leefgebieden } \\
\hline Financiële problemen/zorgen (bijv. schulden) (niet=ref.) & 0,070 & 0,040 & 0,080 \\
\hline Contacten met justitie of politie (niet=ref.) & $-0,082$ & 0,044 & 0,059 \\
\hline Drugsgebruik (soft- of harddrugs) (niet=ref.) & 0,023 & 0,069 & 0,738 \\
\hline Veelvuldig gebruik van internet/gokspellen/computergames (niet=ref.) & $-0,014$ & 0,031 & 0,652 \\
\hline Problemen met woonsituatie (niet=ref.) & $-0,044$ & 0,035 & 0,211 \\
\hline Problemen met familie/ouders/verzorgers (niet=ref.) & 0,104 & 0,049 & 0,035 \\
\hline \multicolumn{4}{|l|}{ Persoonlijke voorkeuren } \\
\hline Een opleiding doen die ik leuk vind <-> een opleiding doen waar ik een baan mee kan vinden & 0,023 & 0,007 & 0,002 \\
\hline $\begin{array}{l}\text { Doorleren totdat ik een diploma heb behaald op het voor mij hoogst haalbare niveau <-> gaan } \\
\text { werken zodra dat kan }\end{array}$ & 0,006 & 0,007 & 0,340 \\
\hline $\begin{array}{l}\text { Een opleiding doen waarmee ik mijn kansen op het volgen van vervolgopleidingen vergroot <-> } \\
\text { een opleiding doen die mijn kansen op het vinden van werk vergroot }\end{array}$ & 0,013 & 0,007 & 0,069 \\
\hline $\begin{array}{l}\text { Na afronding van mijn opleiding zo snel mogelijk kunnen gaan werken }<->\text { na afronding van } \\
\text { mijn opleiding werk hebben dat aansluit bij mijn gevolgde opleiding }\end{array}$ & 0,005 & 0,006 & 0,448 \\
\hline $\begin{array}{l}\text { Ik laat mij bij het nemen van beslissingen graag adviseren door anderen }<->\text { Ik neem } \\
\text { beslissingen graag zelfstandig }\end{array}$ & $-0,010$ & 0,006 & 0,133 \\
\hline \multicolumn{4}{|l|}{ Door respondent waargenomen kenmerken van de school } \\
\hline $\begin{array}{l}\text { School heeft (behalve gesprekken) activiteiten ondernomen om te helpen bij het maken van } \\
\text { studiekeuzes (niet=ref.) }\end{array}$ & $-0,100$ & 0,021 & 0,000 \\
\hline Constante & 0,180 & & \\
\hline
\end{tabular}

$\mathrm{n}=2971$

Bron: Enquĕte onder MBO-gediplomeerden 
Bijlage 7

Kans dat een VMBO-instromer in het MBO-BOL aangeeft als gevolg van het studiekeuzegesprek van studiekeuze te zijn gewisseld.

\begin{tabular}{|c|c|c|c|}
\hline & B & S.E. & Sig \\
\hline \multicolumn{4}{|l|}{ Ingeschatte arbeidsmarktkansen van de eerst studiekeuze } \\
\hline (heel) Moeilijk & 0,046 & 0,068 & 0,500 \\
\hline Niet moeilijk maar ook niet makkelijk & ref. & & \\
\hline (heel) Makkelijk & 0,024 & 0,092 & 0,798 \\
\hline \multicolumn{4}{|l|}{ Kenmerken van studiekeuzegesprekken } \\
\hline Gesprek met docent & 0,030 & 0,070 & 0,671 \\
\hline Gesprek met mentor & 0,013 & 0,067 & 0,843 \\
\hline Gesprek met SLB-er & $-0,106$ & 0,070 & 0,127 \\
\hline Gesprek met iemand anders & 0,050 & 0,099 & 0,610 \\
\hline 1 gesprek & $-0,120$ & 0,066 & 0,070 \\
\hline 2 tot 3 gesprekken & ref. & & \\
\hline 4 of meer gesprekken & 0,155 & 0,087 & 0,074 \\
\hline Gesprek in jan-dec 2012 & $-0,181$ & 0,094 & 0,055 \\
\hline Gesprek in jan/feb/mrt 2013 & 0,044 & 0,095 & 0,640 \\
\hline Gesprek in april/mei/juni 2013 & ref. & & \\
\hline Gesprek in jul/aug/sep 2013 & $-0,062$ & 0,079 & 0,431 \\
\hline Gesprek in okt/nov/dec 2013 & $-0,209$ & 0,076 & 0,006 \\
\hline Duur gesprek: $10 \mathrm{~min}$. & 0,034 & 0,072 & 0,636 \\
\hline Duur gesprek: 10-30 min. & ref. & & \\
\hline Duur gesprek: 30 min. of meer & 0,032 & 0,085 & 0,709 \\
\hline Inhoud gesprek: lange termijn & $-0,220$ & 0,063 & 0,001 \\
\hline Inhoud gesprek: arbeidsmarkt & 0,082 & 0,074 & 0,270 \\
\hline Inhoud gesprek: capaciteiten & 0,047 & 0,064 & 0,458 \\
\hline Inhoud gesprek: opleiding waarvoor was aangemeld & $-0,121$ & 0,065 & 0,064 \\
\hline Inhoud gesprek: andere opleidingen & 0,107 & 0,067 & 0,110 \\
\hline Inhoud gesprek: anders & $-0,167$ & 0,093 & 0,071 \\
\hline Oordeel: het gesprek was (heel) nuttig & 0,131 & 0,062 & 0,036 \\
\hline \multicolumn{4}{|l|}{ Sector VMBO } \\
\hline Economie & $-0,165$ & 0,117 & 0,157 \\
\hline Gecombineerde richtingen & $-0,318$ & 0,085 & 0,000 \\
\hline Landbouw & $-0,096$ & 0,148 & 0,514 \\
\hline Techniek & ref. & & \\
\hline Zorg\&Welzijn & $-0,006$ & 0,135 & 0,964 \\
\hline \multicolumn{4}{|l|}{ Leerweg VMBO } \\
\hline BL & 0,088 & 0,127 & 0,488 \\
\hline $\mathrm{KL}$ & 0,140 & 0,121 & 0,249 \\
\hline GL & 0,219 & 0,154 & 0,155 \\
\hline $\mathrm{TL}$ & ref. & & \\
\hline \multicolumn{4}{|l|}{ Eindcijfer VMBO } \\
\hline $5,5 \mathrm{t} / \mathrm{m} 6,9$ & 0,019 & 0,061 & 0,757 \\
\hline $7,0 \mathrm{t} / \mathrm{m} 8,4$ & ref. & & \\
\hline $8,5 \mathrm{t} / \mathrm{m} 10$ & $-0,216$ & 0,246 & 0,379 \\
\hline
\end{tabular}




\begin{tabular}{|c|c|c|c|}
\hline & B & S.E. & Sig. \\
\hline \multicolumn{4}{|l|}{ Persoonlijke kenmerken } \\
\hline Man (vrouw=ref.) & $-0,128$ & 0,066 & 0,054 \\
\hline Leeftijd & 0,029 & 0,046 & 0,528 \\
\hline \multicolumn{4}{|l|}{ Autochtoon } \\
\hline Westerse allochtoon & 0,219 & 0,125 & 0,080 \\
\hline Niet-Westerse allochtoon & 0,039 & 0,095 & 0,684 \\
\hline Opleidingsniveau vader: basisonderwijs & $-0,014$ & 0,069 & 0,837 \\
\hline Opleidingsniveau vader: voortgezet onderwijs of lager beroepsonderwijs & ref. & & \\
\hline Opleidingsniveau vader: hoger onderwijs & $-0,001$ & 0,081 & 0,989 \\
\hline \multicolumn{4}{|l|}{ Regio woonachtig } \\
\hline Drenthe & 0,085 & 0,161 & 0,598 \\
\hline Flevoland & $-0,031$ & 0,180 & 0,864 \\
\hline Friesland & 0,121 & 0,142 & 0,394 \\
\hline Gelderland & $-0,214$ & 0,088 & 0,015 \\
\hline Groningen & $-0,174$ & 0,141 & 0,218 \\
\hline Limburg & $-0,072$ & 0,125 & 0,566 \\
\hline Noord-Brabant & 0,073 & 0,102 & 0,475 \\
\hline Noord-Holland & $-0,009$ & 0,111 & 0,934 \\
\hline Overijssel & $-0,130$ & 0,120 & 0,280 \\
\hline Utrecht & $-0,068$ & 0,147 & 0,644 \\
\hline Zeeland & 0,024 & 0,200 & 0,903 \\
\hline \multicolumn{4}{|l|}{ Zuid-Holland (ref.) } \\
\hline \multicolumn{4}{|l|}{ Ervaren problemen in leefgebieden } \\
\hline Financiële problemen/zorgen (bijv. schulden) (niet=ref.) & $-0,145$ & 0,119 & 0,221 \\
\hline Contacten met justitie of politie (niet=ref.) & 0,568 & 0,053 & 0,000 \\
\hline Drugsgebruik (soft- of harddrugs) (niet=ref.) & $-0,240$ & 0,154 & 0,119 \\
\hline Veelvuldig gebruik van internet/gokspellen/computergames (niet=ref.) & 0,284 & 0,121 & 0,019 \\
\hline Problemen met woonsituatie (niet=ref.) & 0,051 & 0,167 & 0,759 \\
\hline Problemen met familie/ouders/verzorgers (niet=ref.) & $-0,106$ & 0,128 & 0,407 \\
\hline \multicolumn{4}{|l|}{ Persoonlijke voorkeuren } \\
\hline $\begin{array}{l}\text { Een opleiding doen die ik leuk vind <-> een opleiding doen waar ik een baan mee kan } \\
\text { vinden }\end{array}$ & 0,017 & 0,029 & 0,556 \\
\hline $\begin{array}{l}\text { Doorleren totdat ik een diploma heb behaald op het voor mij hoogst haalbare niveau <-> } \\
\text { gaan werken zodra dat kan }\end{array}$ & 0,024 & 0,027 & 0,374 \\
\hline $\begin{array}{l}\text { Een opleiding doen waarmee ik mijn kansen op het volgen van vervolgopleidingen vergroot } \\
<->\text { een opleiding doen die mijn kansen op het vinden van werk vergroot }\end{array}$ & $-0,033$ & 0,028 & 0,238 \\
\hline $\begin{array}{l}\text { Na afronding van mijn opleiding zo snel mogelijk kunnen gaan werken }<->\text { na afronding } \\
\text { van mijn opleiding werk hebben dat aansluit bij mijn gevolgde opleiding }\end{array}$ & 0,001 & 0,027 & 0,967 \\
\hline $\begin{array}{l}\text { Ik laat mij bij het nemen van beslissingen graag adviseren door anderen <-> Ik neem } \\
\text { beslissingen graag zelfstandig }\end{array}$ & 0,000 & 0,028 & 0,987 \\
\hline \multicolumn{4}{|l|}{ Door respondent waargenomen kenmerken van de school } \\
\hline $\begin{array}{l}\text { School heeft (behalve gesprekken) activiteiten ondernomen om te helpen bij het maken van } \\
\text { studiekeuzes (niet=ref.) }\end{array}$ & 0,108 & 0,068 & 0,114 \\
\hline Constante & 0,429 & & \\
\hline
\end{tabular}

$\mathrm{n}=415$

Bron: Enquĕte onder MB0-gediplomeerden 